\title{
Results of Detailed Hydrologic Characterization Tests - Fiscal Yeer 2000
}

\author{
F. A. Spane, Jr. \\ P. D. Thorne \\ D. R. Newcomer
}

May 2001

Prepared for the U.S. D epartment of Energy under Contract DE-AC06-76RL01830 


\title{
DISCLAIMER
}

This report was prepared as an account of work sponsored by an agency of the United States Government. Neither the United States Government nor any agency thereof, nor Battelle Memorial Institute, nor any of their employees, makes any warranty, express or implied, or assumes any legal liability or responsibility for the accuracy, completeness, or usefulness of any information, apparatus, product, or process disclosed, or represents that its use would not infringe privately owned rights. Reference herein to any specific commercial product, process, or service by trade name, trademark, manufacturer, or otherwise does not necessarily constitute or imply its endorsement, recommendation, or favoring by the United States Government or any agency thereof, or Battelle Memorial Institute. The views and opinions of authors expressed herein do not necessarily state or reflect those of the United States Government or any agency thereof.

\author{
PACIFIC NORTHWEST NATIONAL LABORATORY \\ operated by \\ BATTELLE \\ for the \\ UNITED STATES DEPARTMENT OF ENERGY \\ under Contract DE-AC06-76RL01830
}

Printed in the United States of America

$$
\begin{aligned}
& \text { Available to DOE and DOE contractors from the } \\
& \text { Office of Scientific and Technical Information, } \\
& \text { P.O. Box 62, Oak Ridge, TN 37831-0062; } \\
& \text { ph: (865) 576-8401 } \\
& \text { fax: (865) 576-5728 } \\
& \text { email: reports@adonis.osti.gov }
\end{aligned}
$$

\footnotetext{
Available to the public from the National Technical Information Service, U.S. Department of Commerce, 5285 Port Royal Rd., Springfield, VA 22161 ph: (800) 553-6847 fax: $(703) 605-6900$

email: orders@ntis.fedworld.gov

online ordering: http://www.ntis.gov/ordering.htm
} 


\title{
Results of Detailed Hydrologic Characterization Tests - Fiscal Year 2000
}

\author{
F. A. Spane, Jr. \\ P. D. Thorne \\ D. R. Newcomer
}

May 2001

Prepared for

the U.S. Department of Energy

under Contract DE-AC06-76RL01830

Pacific Northwest National Laboratory

Richland, Washington 99352 


\begin{abstract}
This report provides the results of detailed hydrologic characterization tests conducted within newly constructed Hanford Site wells during fiscal year 2000. Detailed characterization tests performed included groundwater-flow characterization; barometric response evaluation; slug tests; single-well tracer tests; constant-rate pumping tests; and in-well, vertical flow tests. Hydraulic property estimates obtained from the detailed hydrologic tests include transmissivity; hydraulic conductivity; specific yield; effective porosity; in-well, lateral flow velocity; aquifer-flow velocity; vertical distribution of hydraulic conductivity (within the well-screen section); and in-well, vertical flow velocity. In addition, local groundwaterflow characteristics (i.e., hydraulic gradient and flow direction) were determined for four sites where detailed well testing was performed.
\end{abstract}




\section{Summary}

The Pacific Northwest National Laboratory, ${ }^{(a)}$ as part of the Hanford Groundwater Monitoring Project, examines the potential for offsite migration of contamination within underlying aquifer systems. Hydraulic property estimates obtained from the analysis of hydrologic tests are important for evaluating aquifer-flow characteristics (i.e., groundwater-flow velocity) and transport travel time. This report presents test results obtained from the detailed hydrologic characterization program of the unconfined aquifer system conducted for the Hanford Groundwater Monitoring Project during fiscal year (FY) 2000. Hydrologic tests conducted as part of the detailed program include the following:

- slug testing (11 wells tested)

- tracer-dilution tests (5 wells tested)

- tracer-pumpback tests (5 wells tested)

- constant-rate pumping tests (5 wells tested)

- vertical flow, in-well tracer tests (2 wells tested).

Hydraulic property estimates obtained from the detailed hydrologic tests include hydraulic conductivity; transmissivity; specific yield; effective porosity; in-well, lateral, groundwater-flow velocity; aquifer groundwater-flow velocity; vertical distribution of hydraulic conductivity; and in-well, vertical flow velocity. In addition, local groundwater-flow characteristics (i.e., hydraulic gradient, flow direction) were determined for four sites that had detailed well testing performed. Pertinent results from the FY 2000 detailed characterization program are summarized below.

Slug-test results provided hydraulic conductivity estimates for the Ringold Formation (gravel Unit E) that range between 1.4 and $19.9 \mathrm{~m} / \mathrm{d}$ for the eight 200-West Area wells, 41.8 and $52.1 \mathrm{~m} / \mathrm{d}$ for the two 200-East Area wells (reworked gravel Unit E of Plio-Pleistocene age), and 1.7 to $2.0 \mathrm{~m} / \mathrm{d}$ for the Ringold Formation (gravel Unit A) for the one 600-Area well tested. The results fall within the previously reported slug-test values for the Ringold and Hanford formations within the 200-West and 200-East Areas.

The hydraulic conductivity estimates derived from slug tests correspond closely with values obtained from constant-rate pumping tests and fall within the error range commonly reported for slug tests in aquifer characterization studies (i.e., within a factor of $\sim 2$ or less). The close correspondence between slug-test and pumping-test hydraulic conductivity estimates also indicates that the tested formation can be represented as a homogeneous unit at the slug-test or larger scale.

Constant-rate pumping-test results for transmissivity ranged between 125 and $1130 \mathrm{~m}^{2} / \mathrm{d}$ (average $550 \mathrm{~m}^{2} / \mathrm{d}$ ). These values fall within, to slightly above, recently calculated values for the central 200-West Area. The recent estimates were based on the analysis of constant-rate pumping tests conducted during FY 1999, which ranged between 66 and $345 \mathrm{~m}^{2} / \mathrm{d}$ (average $157 \mathrm{~m}^{2} / \mathrm{d}$ ), or the analysis of induced areal

(a) Pacific Northwest National Laboratory is operated for the U.S. Department of Energy by Battelle. 
composite pumping/injection effects of the 200-ZP-1 pump-and-treat system, which produced large-scale estimates that range between 230 and $430 \mathrm{~m}^{2} / \mathrm{d}$ (average $325 \mathrm{~m}^{2} / \mathrm{d}$ ).

Results of pumping tests also correspond fairly closely for specific yield, ranging between 0.09 and 0.16 . These results are comparable with previously reported estimates of 0.11 and 0.17 for the 200-West Area (i.e., Spane et al. 2001). These earlier estimates were based on analyzing the growth and decline of the groundwater mound beneath the 200-West Area associated with wastewater-disposal practices in the area.

Results of tracer-dilution tests indicated that two of the five sites (i.e., wells 299-W22-49 and 69943-44) exhibited in-well, upward, vertical flow conditions that compromise the results of the tracer test. The indicated flow condition within the wells was corroborated using either one or two additional test methods: in-well vertical tracer tests and electromagnetic flow-meter surveys. The fact that the tracer tests and flow-meter survey were conducted nearly 3 months apart, and still provided consistent results, suggests that the upward vertical flow condition is a persistent characteristic at these well sites.

Estimates for average, in-well, lateral flow velocity from tracer-dilution tests for the three sites not exhibiting vertical flow ranged between 0.007 to $0.311 \mathrm{~m} / \mathrm{d}$. The highest value $(0.311 \mathrm{~m} / \mathrm{d})$ was calculated for well 299-W15-41, which is located near the 200-ZP-1 extraction well pump-and-treat facilities. This well is within the potential radius of influence of the pump-and-treat system, which could produce elevated in-well flow velocities.

A comparison of the observed depth versus velocity profiles from tracer-dilution tests provided information about the permeability distribution within the well-screen sections at three well sites. At well 299-W15-41, the highest flow velocities (and inferred permeabilities) were exhibited near the middle and lower section of the well screen, while at well 299-W22-48 the highest flow velocities were indicated near the top. In contrast, well 299-W22-50 exhibited relatively uniform depth well-velocity profiles, indicating homogeneous permeability conditions throughout the well-screen section.

Estimates for effective porosity from the three reportable tracer-pumpback tests ranged between 0.068 and 0.354 . This range falls within to slightly above that commonly reported for semiconsolidated to unconsolidated alluvial aquifers (0.05 to 0.30$)$ and encompasses the large-scale values for specific yield (0.09 and 0.16) derived from the constant-rate pumping-test results.

Estimates for groundwater-flow velocity within the aquifer from the three reportable tracer-pumpback tests ranged between 0.013 and $0.374 \mathrm{~m} / \mathrm{d}$ and, generally, are within a factor of 2.5 of the calculated in-well flow velocities. As noted previously for well 299-W15-41, the calculated high aquifer-flow velocity estimate $(0.374 \mathrm{~m} / \mathrm{d})$ at this well site may be elevated as a result of the effects imposed by operation of the adjacent 200-ZP-1 pump-and-treat system.

Groundwater-flow characterization results for four of the detailed hydrologic characterization sites, based on trend-surface analysis of surrounding well water-level elevations, provided hydraulic gradients that range between 0.00129 and 0.00206 . The trend-surface analysis results also indicated groundwater flows toward the east and southeast. The hydraulic gradient and calculations of flow direction are consistent with previous generalizations for these areas. 


\section{Acknowledgments}

Several Pacific Northwest National Laboratory staff contributed to the hydrologic tests presented in this report. In particular, Kirk Cantrell provided laboratory and field support for the tracer tests. Tyler Gilmore participated in the performance and data acquisition of some of the field tests. Alex Mitroshkov performed laboratory bromide analyses on discrete water samples collected during tracer-pumpback tests. Bruce Williams and Steve Reidel provided identification of hydrogeologic units tested at the well site. The field-testing personnel and test equipment support provided by Duratek Federal Services, Inc. is also acknowledged.

In addition, Pacific Northwest National Laboratory staff also provided significant contributions to this report's preparation. Technical peer review comments were provided by Tyler Gilmore and Stuart Luttrell. The detailed editorial review given by Launa Morasch is also acknowledged. Thanks are also extended to Signe Wurstner for providing hydrologic testing software support. In addition, L. C. Swanson and W. J. McMahan of CH2M-HILL Hanford, G. A. Day of Bechtel Hanford, Inc., and M. J. Furman of the U.S. Department of Energy, Richland Operations Office, also provided technical peer review comments. 


\section{Nomenclature}

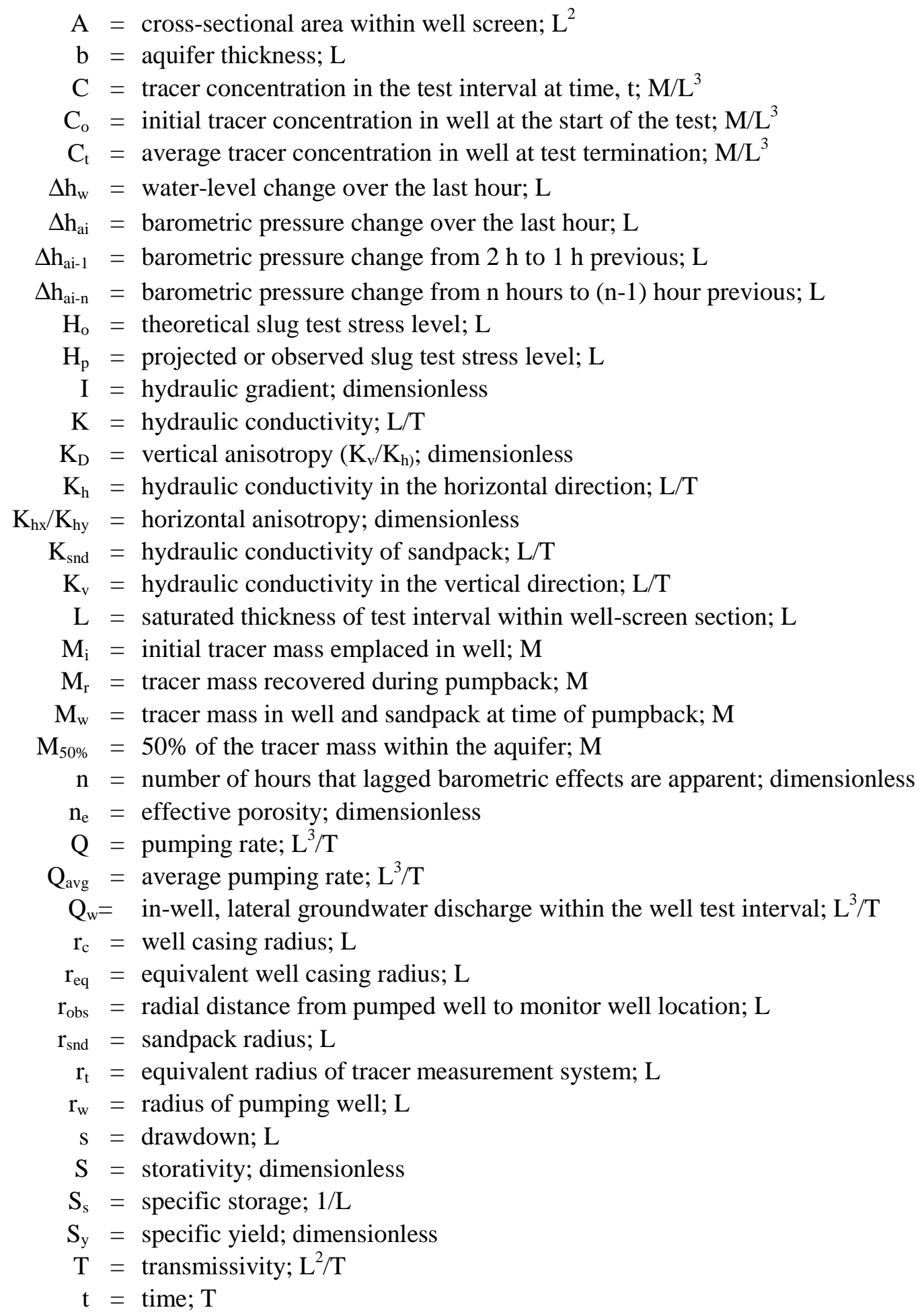




$$
\begin{aligned}
\mathrm{t}_{\mathrm{d}} & =\text { tracer dilution or drift time; } \mathrm{T} \\
\mathrm{t}_{\mathrm{p}} & =\text { pumping time required to recover } 50 \% \text { of the tracer; } \mathrm{T} \\
\mathrm{t}_{\mathrm{t}} & =\text { total elapsed tracer time, equal to } \mathrm{t}_{\mathrm{d}}+\mathrm{t}_{\mathrm{p}} ; \mathrm{T} \\
\mathrm{V} & =\text { test interval well volume; } \mathrm{L}^{3} \\
\mathrm{v}_{\mathrm{a}} & =\text { groundwater-flow velocity within aquifer; } \mathrm{L} / \mathrm{T} \\
\mathrm{v}_{\mathrm{w}} & =\text { groundwater-flow velocity within well; } \mathrm{L} / \mathrm{T} \\
\mathrm{V}_{\mathrm{wz}} & =\text { groundwater-flow velocity for individual depths within well; } \mathrm{L} / \mathrm{T} \\
\mathrm{X}_{0} \ldots \mathrm{X}_{\mathrm{n}} & =\text { regression coefficients corresponding to time lags of } 0 \text { to } \mathrm{n} \text { hours; dimensionless } \\
\mathrm{Y}_{\mathrm{o}} & =\text { slug test stress level; } \mathrm{L} \\
\sigma & =\text { dimensionless unconfined aquifer parameter, equal to } \mathrm{S} / \mathrm{S}_{\mathrm{y}} \\
\propto & =\text { groundwater-flow distortion factor; dimensionless, common range } 0.5 \text { to } 4
\end{aligned}
$$




\section{Contents}

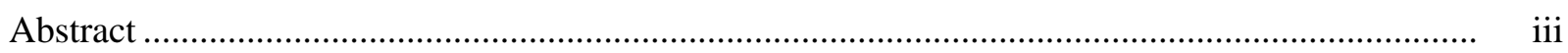

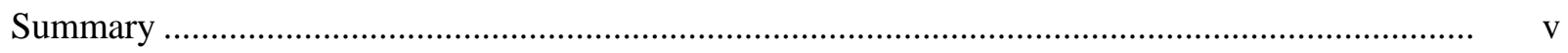

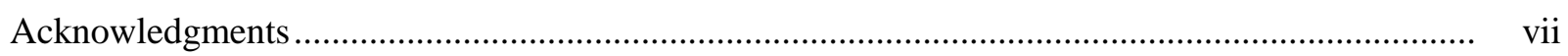

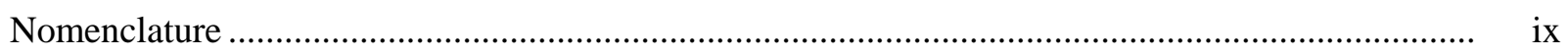

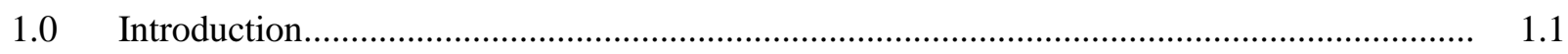

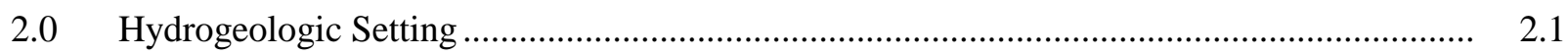

2.1 Hydrogeology of the 200-West Area .................................................................. 2.1

2.2 Hydrogeology of the 200-East Area........................................................................ 2.4

3.0 Detailed Test Characterization Methods.................................................................. 3.1

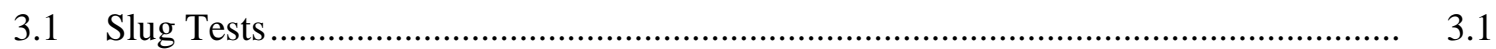

3.1.1 Bouwer and Rice Method ...................................................................... 3.2

3.1.2 Type-Curve Method............................................................................... 3.4

3.1.3 Heterogeneous Formation Analysis...................................................... 3.5

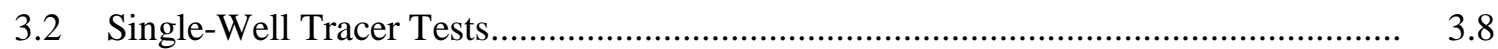

3.2.1 Tracer-Dilution Tests ..................................................................... 3.8

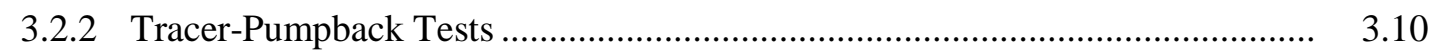

3.2.3 In-Well, Vertical Flow Tests ................................................................ 3.12

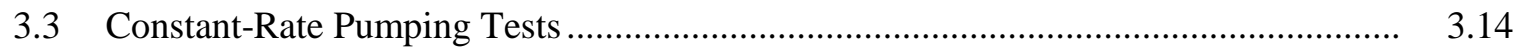

3.3.1 Test Methods and Equipment .......................................................... 3.14

3.3.2 Barometric Pressure Effects Removal ....................................................... $\quad 3.15$

3.3.3 Diagnostic Analysis and Derivative Plots ................................................... 3.16

3.3.4 Type-Curve-Matching Analysis Methods ............................................... 3.17

3.3.5 Straight-Line Analysis Methods ............................................................... 3.18

3.4 Groundwater-Flow Characterization............................................................... 3.19

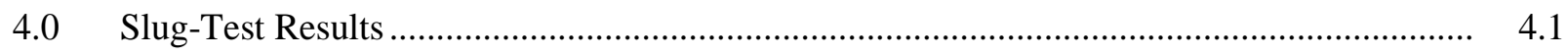

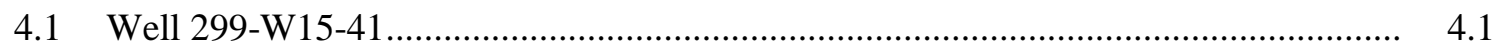

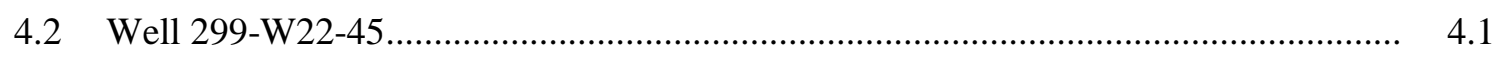

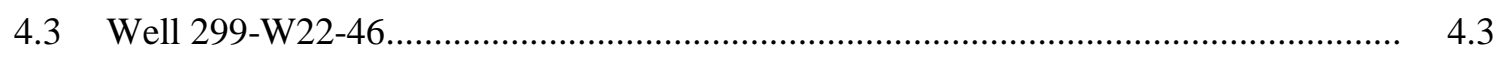




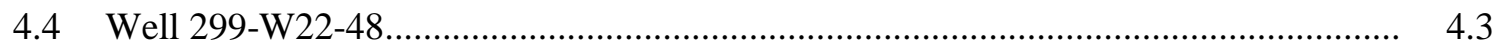

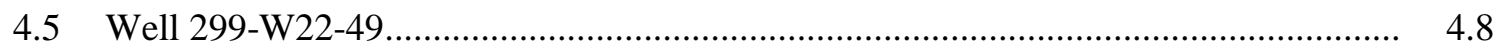

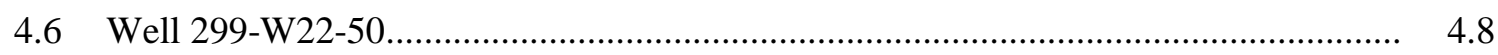

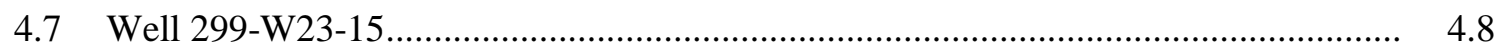

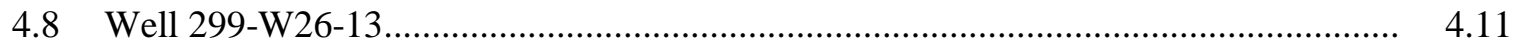

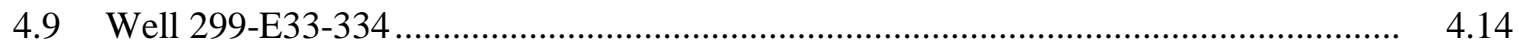

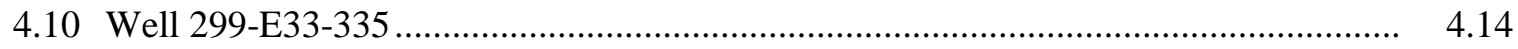

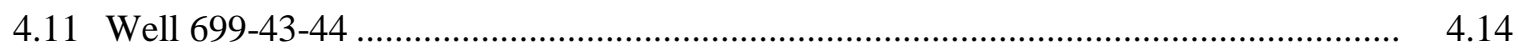

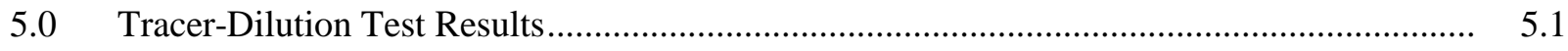

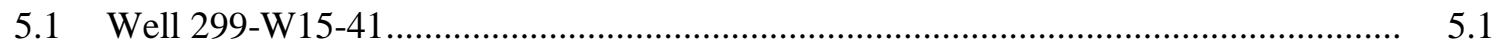

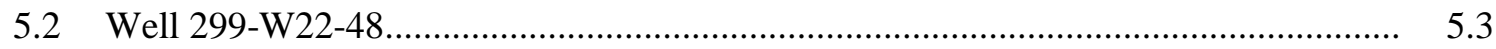

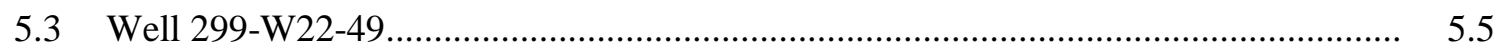

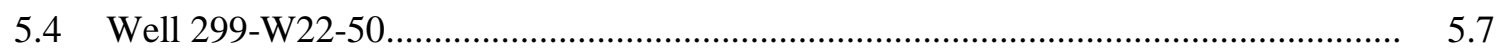

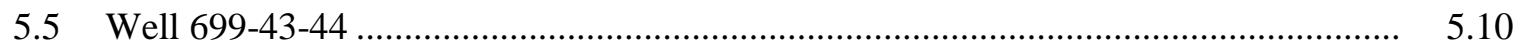

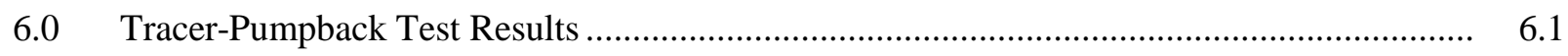

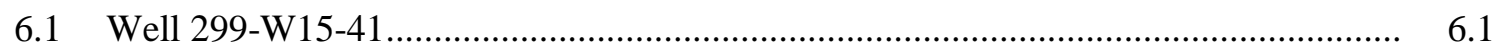

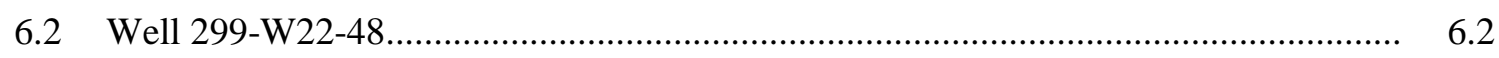

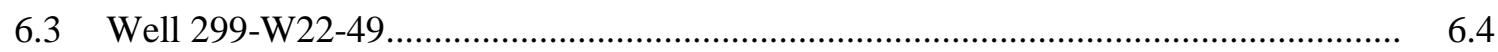

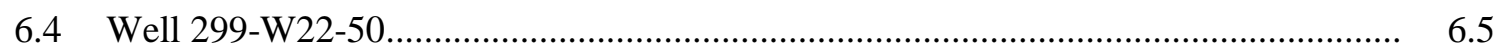

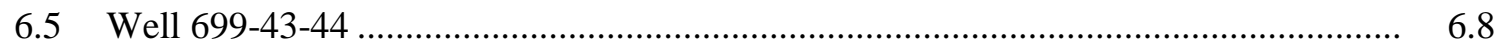

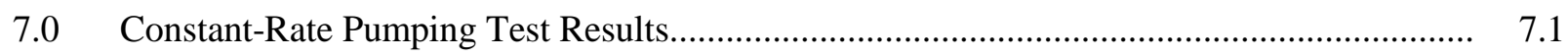

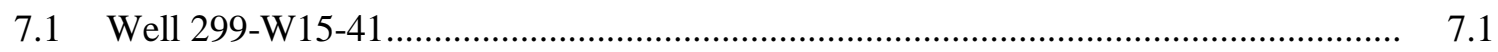

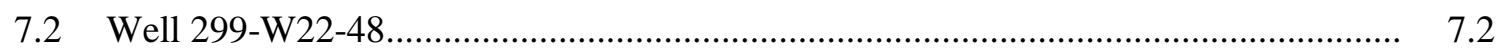

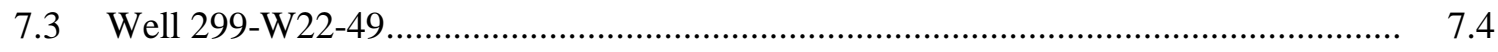




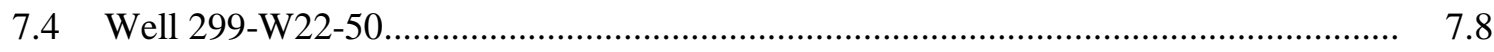

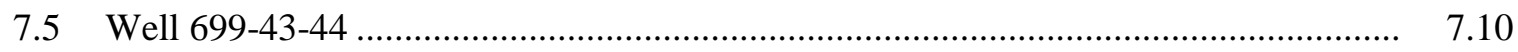

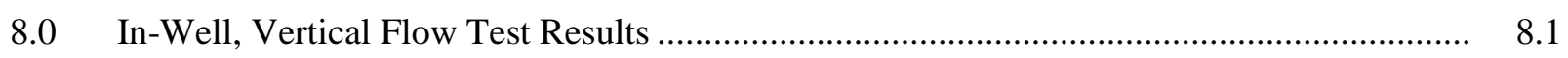

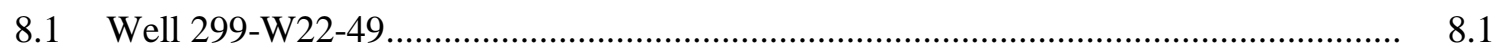

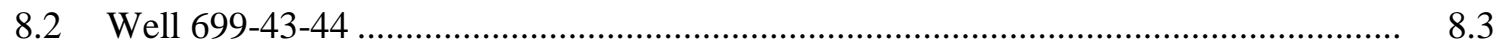

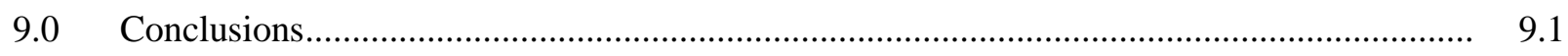

9.1 Slug-Test and Constant-Rate Pumping Test Results........................................... 9.1

9.2 Tracer-Dilution Test Results ........................................................................... 9.2

$9.3 \quad$ Tracer-Pumpback Test Results........................................................................ 9.3

9.4 In-Well, Vertical Flow-Test Results …............................................................. 9.4

9.5 Groundwater-Flow Characterization Results ....................................................... 9.5

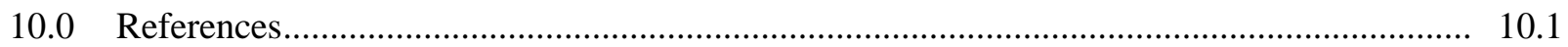




\section{Figures}

$1.1 \quad$ Location Map of Wells Tested During Fiscal Year 2000 ................................................... 1.3

2.1 Stratigraphic Relationships of Various Hydrogeologic Units ............................................. 2.2

2.2 Hydrogeologic Cross Section Through 200-West and 200-East Areas................................. 2.3

3.1 Predicted Slug-Test Response for Nonelastic Formation, Elastic Formation, and High Hydraulic Conductivity Sand-Pack Conditions............................................................... 3.3

3.2 Predicted Slug Test Response: Negative Finite-Thickness Skin Conditions ....................... 3.6

3.3 Predicted Slug Test Derivative Response: Negative Finite-Thickness Skin Conditions......... 3.7

3.4 Predicted Slug Test Response: Positive Finite-Thickness Skin Conditions ......................... 3.8

3.5 Hypothetical Tracer-Dilution Pattern Indicative of Vertical, In-Well, Downward Flow......... 3.13

3.6 Characteristic Log-Log Drawdown and Drawdown Derivative Plots for Various Hydrogeologic Formation and Boundary Conditions........................................................... 3.17

4.1 Comparison of Hydraulic Conductivity Estimates Obtained Using Bouwer and Rice and Type-Curve Analysis Methods ..................................................................................... 4.3

4.2 Selected Slug-Test Analysis Plots for Well 299-W15-41 „............................................ 4.4

4.3 Selected Slug-Test Analysis Plots for Well 299-W22-45 ................................................. 4.5

4.4 Selected Slug-Test Analysis Plots for Well 299-W22-46 ............................................. 4.6

4.5 Selected Slug-Test Analysis Plots for Well 299-W22-48 ............................................... 4.7

4.6 Selected Slug-Test Analysis Plots for Well 299-W22-49 _................................................ 4.9

4.7 Selected Slug-Test Analysis Plots for Well 299-W22-50 ................................................ 4.10

4.8 Selected Slug-Test Analysis Plots for Well 299-W23-15 ................................................ 4.12

4.9 Selected Slug-Test Analysis Plots for Well 299-W26-13 ….............................................. 4.13

4.10 Selected Slug-Test Analysis Plots for Well 299-E33-334 ................................................. 4.15

4.11 Selected Slug-Test Analysis Plots for Well 299-E33-335 ..................................................

4.12 Selected Slug-Test Analysis Plots for Well 699-43-44 _................................................... 4.17 
5.1 Average Tracer-Dilution Test Results Within Well 299-W15-41 .................................... 5.2

5.2 Average Tracer-Dilution Test Results Within Well 299-W22-48_.................................... 5.4

5.3 Average Tracer-Dilution Test Results Within Well 299-W22-49................................... 5.6

5.4 Average Tracer-Dilution Test Results for First Test Within Well 299-W22-50 .................. $\quad 5.8$

5.5 Average Tracer-Dilution Test Results for Second Test Within Well 299-W22-50 _.............. 5.9

5.6 Average Tracer-Dilution Test Results Within Well 699-43-44 ...................................... 5.11

6.1 Tracer-Pumpback Test Results for Well 299-W15-41 _................................................ 6.2

6.2 Tracer-Pumpback Test Results for Well 299-W22-48 _................................................... 6.4

6.3 Tracer-Pumpback Test Results for Well 299-W22-49 ..................................................... 6.5

6.4 Tracer-Pumpback Test Results for First Test, Well 299-W22-50 .................................... 6.6

6.5 Tracer-Pumpback Test Results for Second Test, Well 299-W22-50_................................ 6.8

6.6 Tracer-Pumpback Test Results for Second Test, Well 699-43-44 ..................................... 6.9

7.1 Type-Curve and Derivative Plot Analysis of Drawdown and Recovery Test Data for Pumping Well 299-W15-41 .........................................................................................

7.2 Type-Curve and Derivative Plot Analysis of Drawdown and Recovery Test Data for Pumping Well 299-W22-48 ........................................................................................... 7.4

7.3 Type-Curve and Derivative Plot Analysis of Drawdown and Recovery Test Data for Pumping Well 299-W22-49 ........................................................................... $\quad 7.5$

7.4 Type-Curve and Derivative Plot Analysis of Drawdown and Recovery Test Data for Observation Well 299-W22-39 ...............................................................................

7.5 Composite Type-Curve and Derivative Plot Analysis for Pumping Well 299-W22-49 and Observation Well 299-W22-39

7.6 Comparison of Drawdown and Recovery Responses for Pumping Well 299-W22-50, During Test \#1 and Test \#2

7.7 Type-Curve and Derivative Plot Analysis of Drawdown and Recovery Test Data for Pumping Well 299-W22-50, Test \#2.

7.8 Type-Curve and Derivative Plot Analysis of Drawdown and Recovery Test Data for Pumping Well 699-43-44 
8.1 Tracer Concentration Versus Depth-Response Patterns Within Well 299-W22-49 During Tracer-Dilution Testing

8.2 Tracer Concentration Versus Depth-Response Patterns Within Well 699-43-44 During Tracer-Dilution Testing

8.3 Tracer Concentration Versus Depth-Response Patterns Within Well 699-43-44 During In-Well, Vertical Flow Testing and Calculated, Upward, Vertical Flow Velocities.....

8.4 Calculated Average, In-Well, Upward, Vertical Flow Velocity Within Well 699-43-44, Using Center-of-Mass Method

\section{Tables}

1.1 Pertinent As-Built Information for Wells Tested During Fiscal Year 2000......................... 1.4

3.1 Detailed Hydrologic Characterization Elements …......................................................... 3.1

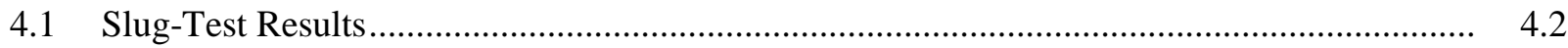

5.1 Tracer-Dilution Test Results for Well 299-W15-41 _........................................................ 5.3

5.2 Tracer-Dilution Test Results for Well 299-W22-48 _.......................................................

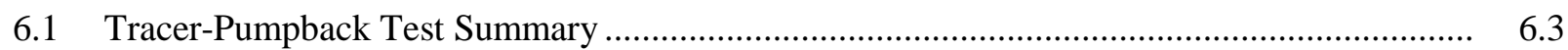

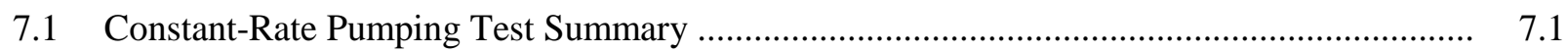

8.1 In-Well, Vertical, Flow-Velocity Calculation Summary for Wells 299-W10-26 and

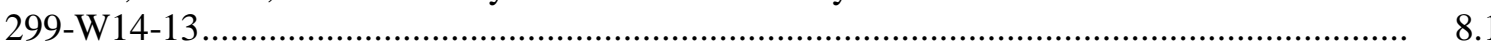

9.1 Hydraulic Property Summary for Slug- and Constant-Rate Pumping Tests ........................ 9.2

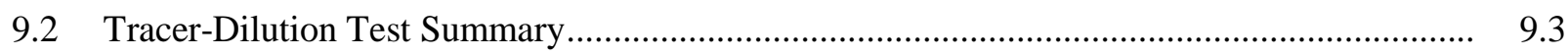

9.3 Groundwater-Flow Characterization Results Based on Trend-Surface Analysis.................. 9.5 


\subsection{Introduction}

Pacific Northwest National Laboratory's Hanford Groundwater Monitoring Project assesses the potential for onsite and offsite migration of contamination within the shallow, unconfined, aquifer system and the underlying, upper, basalt-confined aquifer system at the Hanford Site. As part of this activity, detailed hydrologic characterization tests are conducted within wells at selected Hanford Site locations to provide hydraulic property information and groundwater-flow characterization for the unconfined aquifer. Results obtained from these characterization tests provide hydrologic information that supports the needs of the Resource Conservation and Recovery Act of 1976 (RCRA) facility hydrogeologic characterization and sitewide groundwater-monitoring and -modeling programs and reduces the uncertainty of groundwater-flow conditions at selected locations on the Hanford Site.

This report is the second of a series that provides the results of detailed hydrologic characterization tests conducted within newly constructed Hanford Site wells. In the first report, Spane et al. (2001) presented the results of hydrologic characterization tests conducted during (FY) 1999. In this report, results of tests conducted during fiscal year FY 2000 are provided. The various characterization elements employed in FY 2000, as part of the detailed hydrologic characterization program, include the following:

- groundwater-flow characterization - to quantify the direction of groundwater flow and hydraulic gradient conditions

- barometric response evaluation - to compare the characteristics of well response to barometric fluctuations, estimate vadose zone transmission characteristics, and remove barometric pressure effects from hydrologic test responses

- slug testing - to evaluate well-development conditions and provide preliminary hydraulic property information (e.g., hydraulic conductivity) to design subsequent hydrologic tests

- tracer-dilution test - to determine the vertical distribution of hydraulic conductivity and/or groundwater-flow velocity within the well-screen section and to identify vertical flow conditions within the well column

- tracer-pumpback test - to characterize effective porosity and average, aquifer, groundwater-flow velocity

- constant-rate pumping test - to provide quantitative hydraulic property information (e.g., transmissivity, hydraulic conductivity, storativity, specific yield) when conducted in concert with tracerpumpback phase and analysis of drawdown and recovery data

- in-well vertical tracer test - to calculate in-well, vertical flow velocity within the well-screen section. 
Newly constructed RCRA wells selected for characterization during FY 2000 include the following:

\begin{tabular}{||l|c||}
\hline \multicolumn{1}{|c|}{ Well } & $\begin{array}{c}\text { RCRA Waste } \\
\text { Management Area }\end{array}$ \\
\hline \hline 299-W15-41 & TX-TY \\
\hline 299-W22-48 & SST S-SX \\
\hline 299-W22-49 & SST S-SX \\
\hline 299-W22-50 & SST S-SX \\
\hline 299-W26-13 & 216-S-10 \\
\hline 299-E33-334 & SST B-BX-BY \\
\hline 299-E33-335 & SST B-BX-BY \\
\hline 699-43-44 & B-POND \\
\hline
\end{tabular}

In addition, three existing wells were selected for characterization during FY 2000. They included the following:

\begin{tabular}{||c|c||}
\hline Well & $\begin{array}{c}\text { RCRA Waste } \\
\text { Management Area }\end{array}$ \\
\hline \hline 299-W22-45 & SST S-SX \\
\hline 299-W22-46 & SST S-SX \\
\hline 299-W23-15 & SST S-SX \\
\hline
\end{tabular}

The new RCRA wells are all constructed of 10.16-cm-diameter stainless-steel casing with wirewrapped stainless-steel screens and sand pack. These wells were constructed either to replace older wells that are going dry because of the declining water table (e.g., 200-West Area) or for additional areal coverage. All new wells are screened across the water table and penetrate approximately the top 3 to $10 \mathrm{~m}$ of the aquifer. Five of the test wells (299-W15-41, 299-W22-48, 299-W22-49, 299-W22-50, and 699-43-44) were selected for detailed hydrologic characterization. Figure 1.1 shows the location of the wells tested during FY 2000 in relationship to the 200-West and 200-East Areas of the Hanford Site. The boundaries of the various RCRA waste management areas are shown on site maps contained in Hartman et al. (2000). Table 1.1 provides pertinent as-built and well-completion information for the identified new wells.

This report presents the results of hydrologic characterization conducted at these well sites during FY 2000. Section 2.0 describes the hydrogeologic setting of the 200-West and 200-East Areas, where the test wells are located. Performance and methods used to analyze the various test elements are described in Section 3.0. Section 4.0 presents results obtained from slug testing. Results of tracer-dilution and pumpback tests obtained at four selected test well sites are contained in Sections 5.0 and 6.0, respectively. Section 7.0 presents the results obtained from the constant-rate pumping tests. Calculations of in-well vertical flow determinations are discussed in Section 8.0. Conclusions are given in Section 9.0, followed by references cited in the text in Section 10.0. Also, a list of the scientific nomenclature used throughout this report is provided on page ix. 


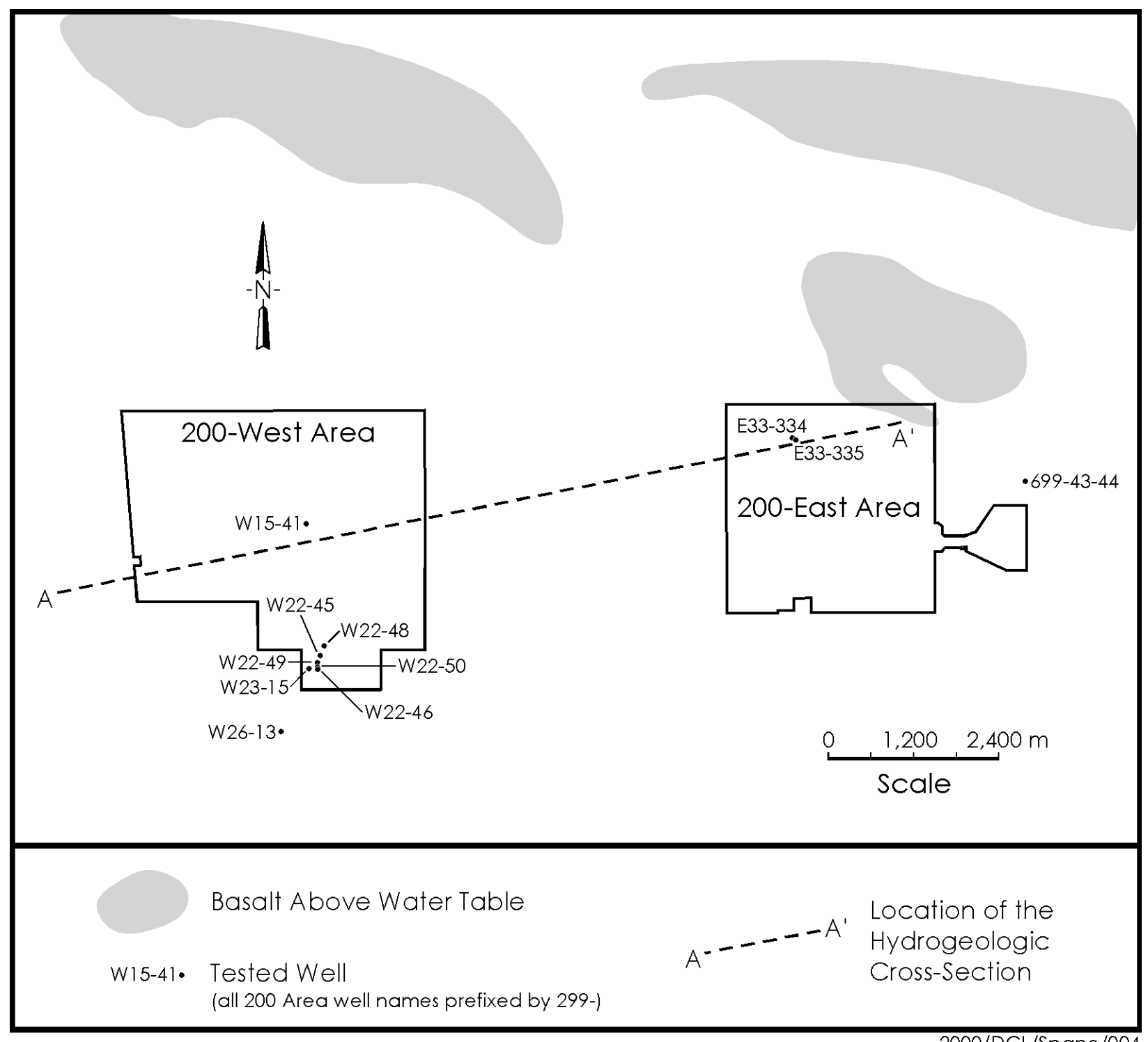

2000/DCL/Spane/004

Figure 1.1. Location Map of Wells Tested During Fiscal Year 2000 
Table 1.1. Pertinent As-Built Information for Wells Tested During Fiscal Year 2000

\begin{tabular}{|c|c|c|c|}
\hline Well & $\begin{array}{c}\text { Ground Surface/Brass-Cap } \\
\text { Elevation, m, } \\
\text { MSL (NAVD88) }\end{array}$ & $\begin{array}{c}\text { Well-Screen Depth Below } \\
\text { Ground Surface/Brass } \\
\text { Cap, m }\end{array}$ & $\begin{array}{l}\text { Saturated Well-Screen } \\
\text { Section, m } \\
\text { MSL (NAVD88) }\end{array}$ \\
\hline 299-W15-41 & 202.79 & $65.81-70.39$ & $\begin{array}{c}137.21-132.40 \\
(4.81)^{(\mathrm{a})}\end{array}$ \\
\hline 299-W22-45 & 203.14 & $60.38-71.29$ & $\begin{array}{c}137.52-131.85 \\
(5.67)\end{array}$ \\
\hline 299-W22-46 & 204.55 & $58.80-69.77$ & $\begin{array}{c}137.50-134.78 \\
(2.72)\end{array}$ \\
\hline 299-W22-48 & 207.13 & $68.96-73.53$ & $\begin{array}{c}137.42-133.60 \\
(3.82)\end{array}$ \\
\hline 299-W22-49 & 203.93 & $66.42-70.99$ & $\begin{array}{c}137.47-132.94 \\
(4.53)\end{array}$ \\
\hline 299-W22-50 & 204.14 & $66.43-71.00$ & $\begin{array}{c}137.44-133.14 \\
(4.30)\end{array}$ \\
\hline 299-W23-15 & 199.80 & $56.60-67.79$ & $\begin{array}{c}137.74-132.01 \\
(5.73)\end{array}$ \\
\hline 299-W26-13 & 199.04 & $61.63-72.33$ & $\begin{array}{c}137.41-126.71 \\
(10.70) \\
\end{array}$ \\
\hline 299-E33-334 & 203.29 & $78.55-86.17$ & $\begin{array}{c}122.76-117.12 \\
(4.81)^{\mathrm{b}}\end{array}$ \\
\hline 299-E33-335 & 203.42 & $79.25-85.35$ & $\begin{array}{c}122.72-118.07 \\
(4.65)\end{array}$ \\
\hline $699-43-44$ & 176.62 & $52.11-58.22$ & $\begin{array}{c}123.30-118.40 \\
(4.90)\end{array}$ \\
\hline \multicolumn{4}{|c|}{$\begin{array}{l}\text { (a) Number in parentheses is saturated thickness. } \\
\text { (b) Well screen extends } 0.83 \mathrm{~m} \text { into underlying basalt flow. Number in parentheses represents the } \\
\text { saturated thickness of only the alluvium. } \\
\text { MSL } \quad=\text { mean sea level. } \\
\text { NAVD88 = North American Vertical Datum of } 1988 .\end{array}$} \\
\hline
\end{tabular}




\subsection{Hydrogeologic Setting}

The hydrogeology of the 200-West and 200-East Areas is described below in terms of two classification systems used for the Hanford Site consolidated groundwater model: the first is based on hydrogeologic units (Thorne et al. 1993) and the second is based strictly on geology (Lindsey 1995). The hydrogeologic classification system subdivides units based on texture, which correlates to hydraulic properties. This geologic classification is based on the lithologic and stratigraphic relationships defined by Lindsey (1995). A comparison of the two classifications is shown in Figure 2.1. The major classification system difference in the vicinity of the 200 Areas is the grouping of the lower sand-dominated portion of Lindsey's upper Ringold with Ringold gravel units E and C to form Thorne's hydrogeologic unit 5. A general west-to-east cross section in Figure 2.2 shows the hydrogeologic units underlying the 200-West and 200-East Areas. Figure 1.1 shows the surface trace of the cross section in relationship to the test wells described in this report.

The brief hydrogeologic description for the 200-West and 200-East Areas presented below is taken primarily from Spane et al. (2001), which is based on the following reports: Graham et al. (1984), Lindsey et al. (1992), Connelly et al. (1992a, 1992b), Thorne et al. (1993), Lindsey (1995), and Williams et al. (2000).

\subsection{Hydrogeology of the 200-West Area}

The aquifer system above the basalt bedrock in the 200-West Area comprises two aquifer systems: an unconfined aquifer and an underlying, locally confined aquifer. The unconfined aquifer lies almost entirely within unit 5 of the Ringold Formation (geologic unit E) (see Figure 2.1) and is composed of fluvial, gravel-dominated sediments with a fine-sand matrix. The FY 2000 results for test wells located in the 200-West Area are reflective of this hydrogeologic unit (unit 5). Sediments within unit 5 exhibit variable degrees of cementation, ranging from partially to well developed. Cemented zones up to several meters thick and extending laterally over several hundred meters have been identified in the 200-West Area. Thin, laterally discontinuous, sand and silt beds also are intercalated in the gravelly deposits.

The lower Ringold mud (unit 8), consisting of overbank and lacustrine deposits, underlies the unconfined aquifer. This mud unit is continuous over the entire 200-West Area but is absent just north of the 200-West Area, where it pinches out. The lower mud unit generally thickens and dips to the south and southwest. The top of the mud unit, which has an irregular surface, forms the lower boundary of the unconfined aquifer in the 200-West Area.

The lower mud separates the unconfined aquifer from an underlying confined aquifer, which is composed of unit 9 (the gravel portion of geologic unit A). Unit 9 is composed of fluvial gravels with lesser amounts of intercalated sands and silts. This basal unit, which lies directly above the basalt bedrock, thickens and dips to the south and southwest. The uppermost basalt formation beneath the 200-West Area is the Saddle Mountains Basalt. 
Hydrogeologic Column

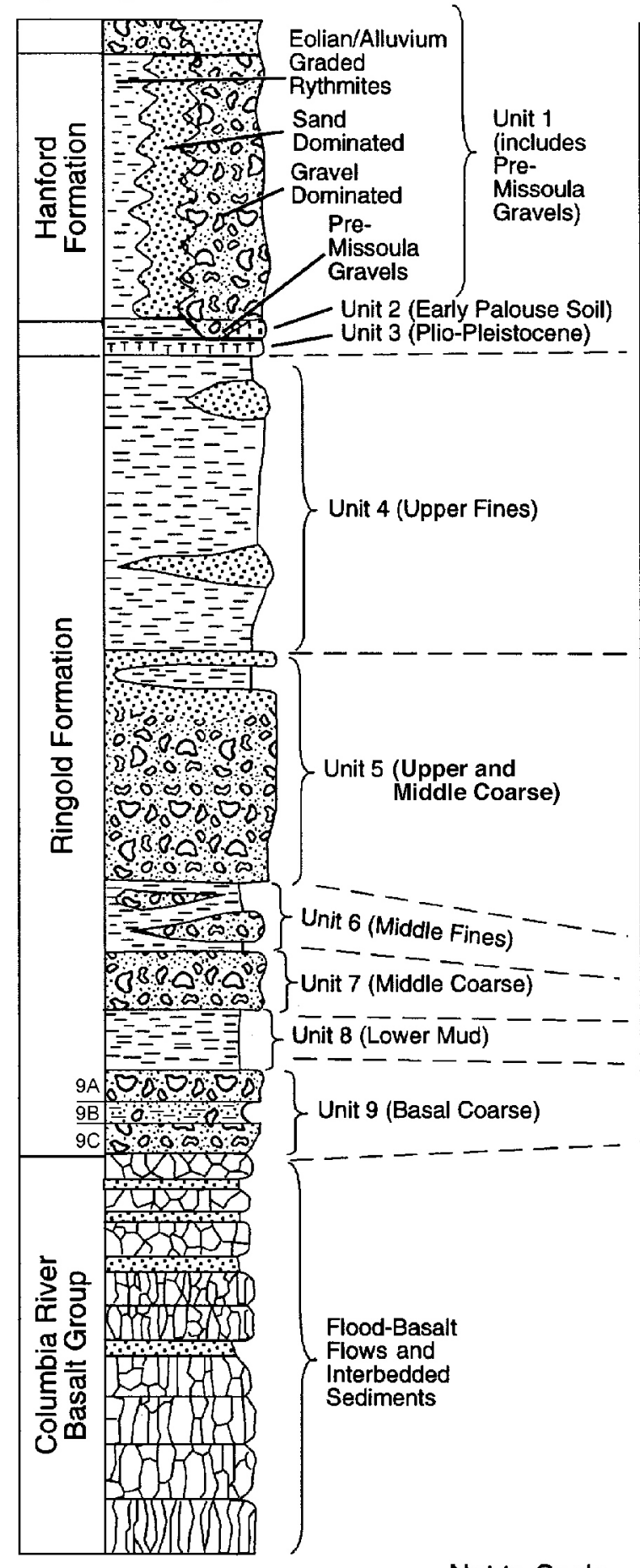

After Thorne et al. (1993)

\section{Geologic Column}

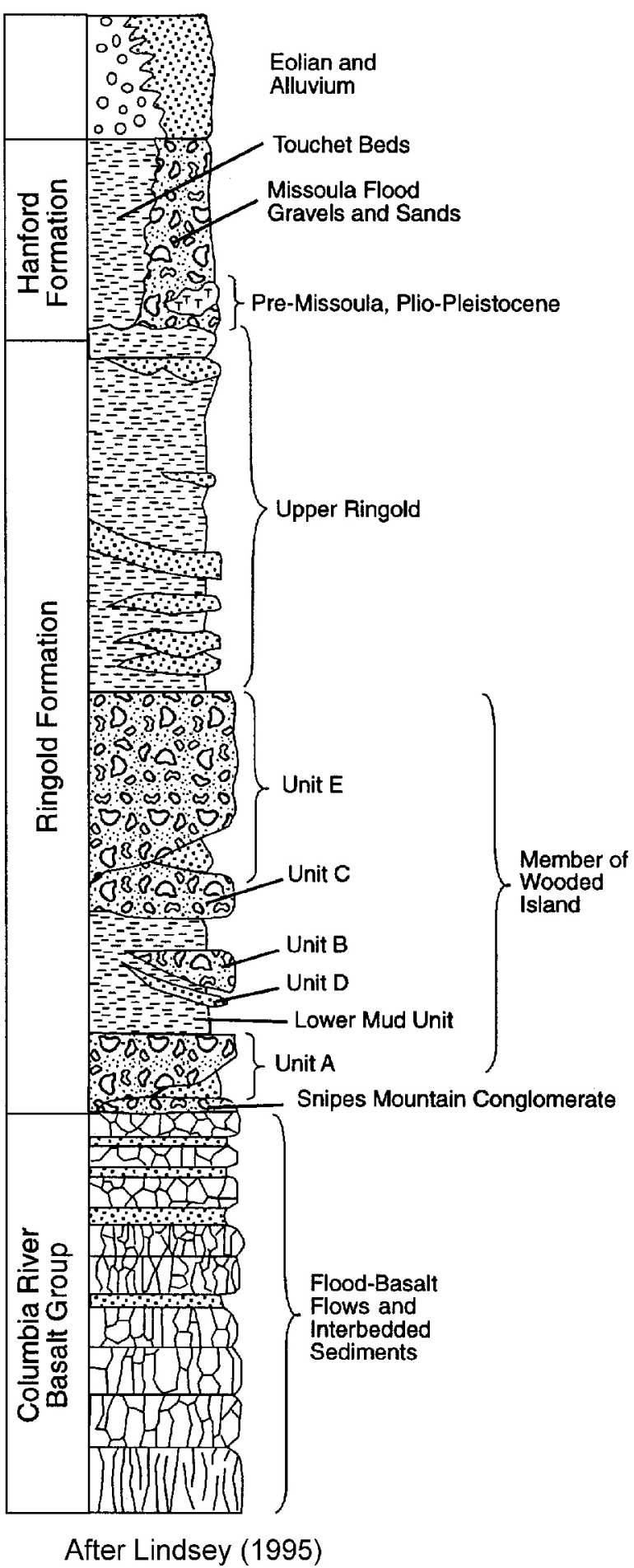

2000/DCL/Spane/001

Figure 2.1. Stratigraphic Relationships of Various Hydrogeologic Units (adapted from Spane et al. 2001) 


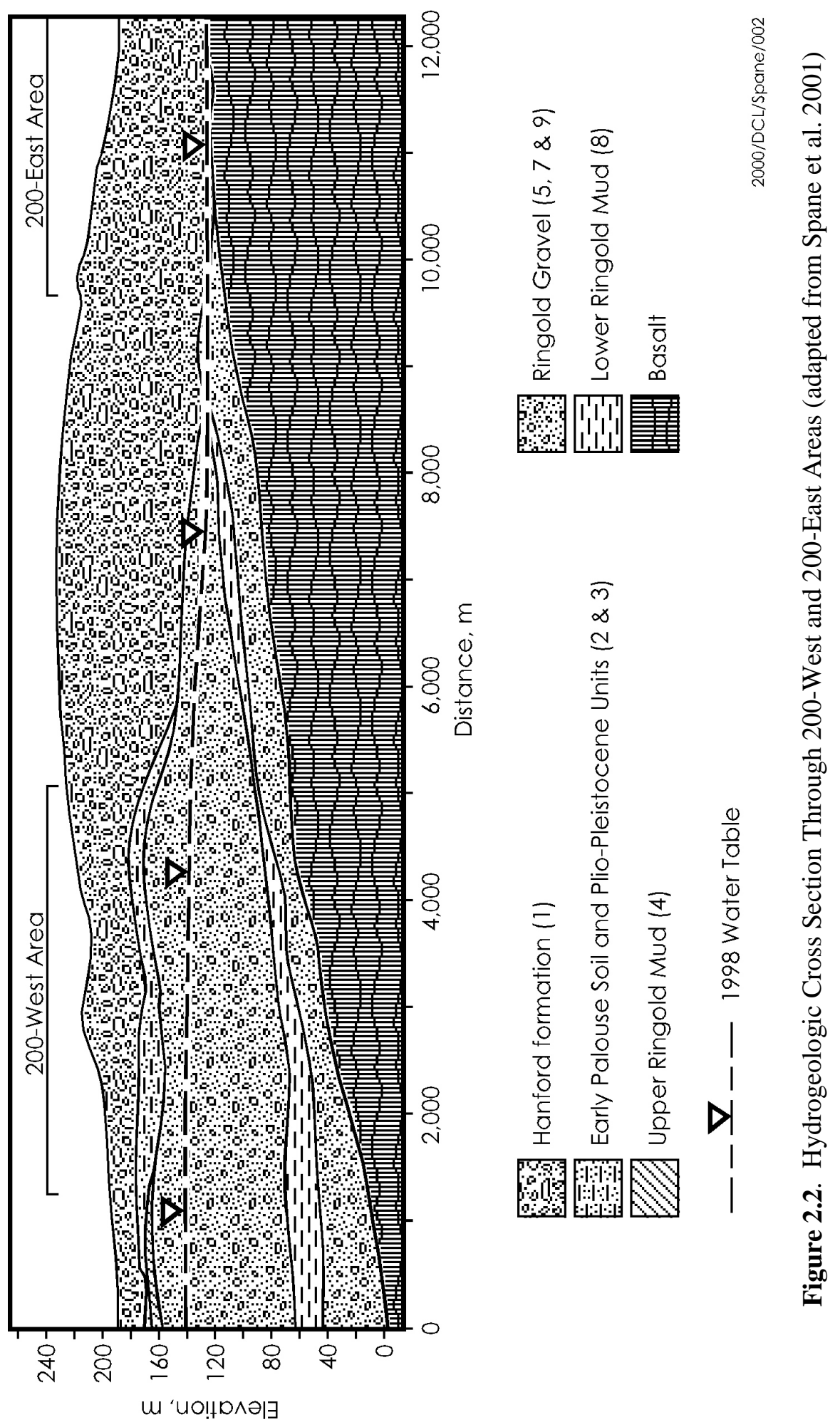




\subsection{Hydrogeology of the 200-East Area}

As in the 200-West Area, the aquifer system above the basalt in the 200-East Area consists of the unconfined aquifer and, in some places, a locally confined aquifer that underlies unit 8 (lower Ringold mud). The unconfined aquifer within the 200-East Area lies within the Hanford formation (unit 1) and/or Ringold Formation gravel (units 5, 7, and 9) (see Figure 2.1). In the northern part of the 200-East Area, the unconfined aquifer is thin in locations where the basalt surface forms subsurface highs. In these locations, the unconfined aquifer lies almost entirely within unit 1. The FY 2000 results for test wells in the 200-East Area are reflective of reworked Ringold gravel unit E of Plio-Pleistocene age. This unit consists primarily of unconsolidated gravel- and sand-dominated sediments. These undifferentiated sediments represent reworking of the Ringold Formation deposits from either the ancestral Columbia River or Missoula flood events. Because of the preponderance of unconsolidated gravel and sand deposits, this unit generally exhibits higher permeabilities than older, non-reworked hydrogeologic units within the Ringold Formation.

The lower boundary of the unconfined aquifer in the 200-East Area is defined by the top of unit 8 , the top of unit 9B (a fine-grained subunit of unit 9), or the top of basalt. To the north of the 200-East Area, the lower Ringold Formation units and underlying upper basalt flows were extensively eroded by the Missoula floods at the time the Hanford formation was deposited. Previous reports have indicated that direct hydrogeologic communication between the unconfined and underlying, upper, basalt-confined aquifer is likely in these areas (Gephart et al. 1979; Graham et al. 1984; Spane and Webber 1995).

Ringold Formation unit 8, which represents the confining mud unit separating the overlying, unconfined aquifer from the underlying, confined, basal Ringold aquifer within unit 9, is composed primarily of low-permeability, fluvial overbank, paleosol, and lacustrine silts and clay, with minor amounts of sand and gravel. As indicated in Figure 2.1, unit 9 is composed of local subunits. Unit 9B consists of poorly characterized silt- to clay-rich zones and represents a relatively thin, low-permeability, local confining unit within the basal Ringold gravel. East of the 200-East Area near the 216-B-3 Pond facility, confining units 8 and $9 \mathrm{~B}$ extend above the regional water table.

Subunits 9A and 9C are composed primarily of fluvial gravels and collectively make up the Ringold confined aquifer within the southern part of the 200-East Area and near the 216-B-3 Pond facility east of the 200-East Area. The Ringold confined aquifer is defined by the lateral boundary of confining layer unit 8 . Where unit 8 has been removed by erosion, the basal Ringold gravel forms part of the unconfined aquifer. This is believed to be the case at well 699-43-44, which was tested during FY 2000. The Ringold confined aquifer thickens to the south and is bounded below by the top of the Saddle Mountains Basalt. 


\subsection{Detailed Test Characterization Methods}

This report provides the results of detailed hydrologic characterization tests conducted within newly constructed Hanford Site wells during FY 2000. Detailed characterization tests performed included groundwater-flow characterization, barometric response evaluation, slug tests, single-well tracer tests (tracer-dilution, tracer-pumpback, and in-well vertical flow tests), and constant-rate pumping tests. Table 3.1 provides a summary of the various hydrologic characterization elements. More in-depth descriptions of the methods used to analyze slug tests, various single-well tracer tests, and constant-rate pumping tests are provided below, and is taken primarily from Spane et al. (2001).

\subsection{Slug Tests}

Because of their ease of implementation and relatively short duration, slug tests are commonly used to provide initial estimates of hydraulic properties (e.g., range and spatial/vertical distribution of hydraulic conductivity, K). Because of the small displacement volumes employed during slug tests, hydraulic properties determined, using this characterization method, are representative of conditions relatively close to the well. For this reason, slug-test results are commonly used in the design of subsequent hydrologic tests having greater areas of investigation (e.g., slug interference [Novakowski 1989; Spane 1996; Spane et al. 1996], constant-rate pumping tests [Butler 1990; Spane 1993]).

Table 3.1. Detailed Hydrologic Characterization Elements

\begin{tabular}{|c|c|c|}
\hline Element & Activities & Results $^{(a)}$ \\
\hline $\begin{array}{l}\text { Groundwater-flow } \\
\text { characterization }\end{array}$ & $\begin{array}{l}\text { Trend-surface analysis of well } \\
\text { water-level data }\end{array}$ & $\begin{array}{l}\text { Quantitative determination of groundwater-flow } \\
\text { direction and hydraulic gradient }\end{array}$ \\
\hline $\begin{array}{l}\text { Barometric response } \\
\text { evaluation }\end{array}$ & $\begin{array}{l}\text { Well water-level response } \\
\text { characteristics to barometric } \\
\text { changes }\end{array}$ & $\begin{array}{l}\text { Aquifer-/well-model identification, vadose zone } \\
\text { property characterization, correction of hydrologic } \\
\text { test responses for barometric pressure fluctuations }\end{array}$ \\
\hline Slug test & $\begin{array}{l}\text { Multistress-level tests } \\
\text { conducted at each well site }\end{array}$ & Local $\mathrm{K}_{\mathrm{h}}, \mathrm{T}$ of aquifer surrounding well site \\
\hline Tracer-dilution test & $\begin{array}{l}\text { Monitoring dilution of admin- } \\
\text { istered tracer at injection well } \\
\text { site }\end{array}$ & Determination of $\mathrm{v}_{\mathrm{w}}$ and vertical distribution of $\mathrm{K}_{\mathrm{h}}$ \\
\hline Tracer-pumpback test & $\begin{array}{l}\text { Pumping/monitoring of } \\
\text { recovered tracer and associated } \\
\text { pressure response in monitor } \\
\text { wells }\end{array}$ & Local- to intermediate-scale $n_{e}$ and $v_{a}$ \\
\hline $\begin{array}{l}\text { In-well vertical tracer } \\
\text { test }\end{array}$ & $\begin{array}{l}\text { Monitoring the vertical move- } \\
\text { ment of tracer within the well } \\
\text { screen }\end{array}$ & $\begin{array}{l}\text { Determination of } \mathrm{v}_{\mathrm{w}} \text { within the monitor well-screen } \\
\text { section }\end{array}$ \\
\hline $\begin{array}{l}\text { Constant-rate pumping } \\
\text { test }\end{array}$ & $\begin{array}{l}\text { Pumping/monitoring of } \\
\text { pressure response in monitor } \\
\text { wells }\end{array}$ & $\begin{array}{l}\text { Intermediate to large-scale, } \mathrm{K}_{\mathrm{h}}, \mathrm{K}_{\mathrm{v}} / \mathrm{K}_{\mathrm{h}}, \mathrm{K}_{\mathrm{hx}} / \mathrm{K}_{\mathrm{hy}}, \mathrm{T}, \mathrm{S} \text {, } \\
\mathrm{S}_{\mathrm{y}}\end{array}$ \\
\hline
\end{tabular}


Slug tests conducted as part of the FY 2000 detailed characterization program were performed by removing a slugging rod (withdrawal test) of known displacement volume. Slug-withdrawal tests were employed rather than slug-injection tests (i.e., by rapidly immersing the slugging rod) because of their reported superior results for unconfined aquifer tests where the water table occurs within the well-screen section (e.g., Bouwer 1989). At all test sites, two different size slugging rods were used to impart varying stress levels for individual slug tests. The slug tests were repeated at each stress level to assess reproducibility of the test results. Comparison of the normalized slug-test responses is useful to assess the effecttiveness of well development and the presence of near-well heterogeneities and dynamic skin effects, as noted in Butler et al. (1996).

Based on volumetric relationships, the two different size slugging rods theoretically impart a slug-test stress level of $0.458 \mathrm{~m}$ (low-stress tests) and $1.117 \mathrm{~m}$ (high-stress tests) within a 0.1016-m inside diameter well. However, for conditions where wells are screened across the water table, as for the Hanford Site wells tested in FY 2000 and where the well-screen sand pack has a relatively high permeability, the actual stress level imposed on the test formation may be lower than the theoretical stress level. This is due to the added volume of the sand pack at the time of test initiation. For these situations, the actual slug-test stress level is determined by projecting the observed early test response back to the time of test initiation. For situations where the theoretical slug-test stress level, $\mathrm{H}_{0}$, is greater than the observed or projected stress level, $\mathrm{H}_{\mathrm{p}}$, an equivalent well radius, $\mathrm{r}_{\mathrm{eq}}$, must be used instead of the actual well-casing radius, $\mathrm{r}_{\mathrm{c}}$, in the various analytical methods. The $\mathrm{r}_{\mathrm{eq}}$ can be calculated by using the following relationship presented in Butler (1998):

$$
\mathrm{r}_{\mathrm{eq}}=\mathrm{r}_{\mathrm{c}}\left(\mathrm{H}_{\mathrm{o}} / \mathrm{H}_{\mathrm{p}}\right)^{1 / 2}
$$

Two different methods were used for the slug-test analysis: the semiempirical, straight-line analysis method described in Bouwer and Rice (1976) and Bouwer (1989) and the type-curve-matching method for unconfined aquifers presented in Butler (1998). A description of the slug-test analysis methods is presented in the following sections. Analysis details and results for slug tests conducted at each of the test wells during FY 2000 are provided in Section 4.0.

\subsubsection{Bouwer and Rice Method}

The Bouwer and Rice method is a well-known technique and is widely applied in the analysis of slug tests. A number of analytical weaknesses, however, limit the successful application of the Bouwer and Rice method for analyzing slug-test response. These weaknesses constrain its application to slug-test responses that exhibit steady-state flow, isotropic conditions, no well-skin effects, and no elastic (storage) formation response. Unfortunately, these limitations are commonly ignored, and the Bouwer and Rice method is applied to slug-test responses that do not meet the test analysis criteria. A more detailed discussion on the analytical limitations of the Bouwer and Rice method is provided in Hyder and Butler (1995), Brown et al. (1995), and Bouwer (1996).

For slug tests exhibiting elastic storage response, it should be noted that improved estimates can be obtained if analysis criteria specified in Butler $(1996,1998)$ are observed. Figure 3.1 shows the predicted, normalized, slug-test response for three well/aquifer-test conditions: 1) nonelastic formation, 2) elastic 


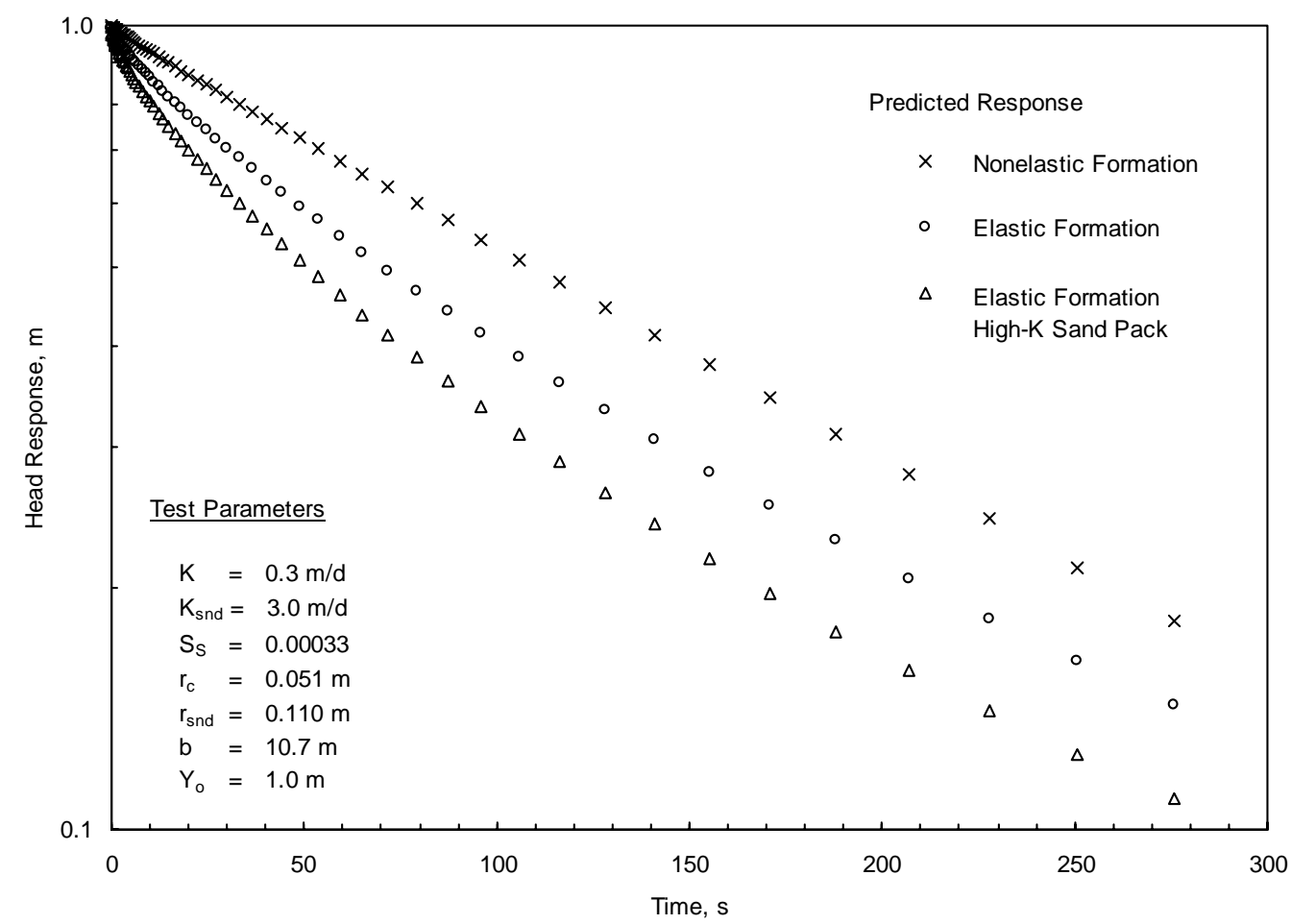

Figure 3.1. Predicted Slug-Test Response for Nonelastic Formation, Elastic Formation, and High Hydraulic Conductivity Sand-Pack Conditions

formation, and 3) elastic formation with high-K sandpack effects. The test responses were calculated using the KGS model described in Liu and Butler (1995) for the given test conditions listed in Figure 3.1. As shown, the presence of elastic aquifer storage (i.e., specific storage, $S_{\mathrm{s}}$ ) and effects of a highpermeability sand pack cause curvilinear test responses (concave upward) that deviate from the predicted linear, nonelastic formation response. When this diagnostic curvilinear response is exhibited in the slugtest response, Butler $(1996,1998)$ recommends that the late-time test analysis be employed (i.e., the normalized head segment between 0.3 and 0.2) when using the Bouwer and Rice (1976) method. As shown in Figure 3.1, the two elastic curvilinear test responses over the specified late-time segment closely parallel the nonelastic test-formation response. This indicates that quantitative estimates for $\mathrm{K}$ can be obtained using the Bouwer and Rice method over a wide range of test-response conditions (nonelastic or elastic formation, high-K sandpack effects), if the proper analysis criteria are applied.

Because of its semiempirical nature, analytical results obtained using the Bouwer and Rice method (i.e., in contrast to results obtained using the type-curve-matching method) may be subject to error. Bouwer and Rice (1976) indicated that the K estimate, using their analysis method, should be accurate to within $10 \%$ to $25 \%$. Hyder and Butler (1995) state an accuracy level for the Bouwer and Rice method within $30 \%$ of actual for homogeneous, isotropic formations, with decreasing levels of accuracy for more complex well/aquifer conditions (e.g., well-skin effects). For these reasons, greater credence is generally afforded the analytical results obtained using the type-curve-matching approach, which has a more rigorous analytical basis. 


\subsubsection{Type-Curve Method}

Because the type-curve method can use all or any part of the slug-test response in the analysis procedure, it is particularly useful for the analysis of unconfined aquifer tests. The method also does not have any of the aforementioned analytical weaknesses of the Bouwer and Rice method. To facilitate the standardization of the slug-test type-curve analyses, a set of initial analysis parameters was assumed:

- a vertical anisotropy, $\mathrm{K}_{\mathrm{D}}$, value of 1.0

- a specific storage, $\mathrm{S}_{\mathrm{s}}$, value of $0.00001 \mathrm{~m}^{-1}$

- the well-screen interval below the water table was assumed to be equivalent to the test-interval section.

To standardize the slug-test type-curve-matching analysis for all slug-test responses, a $1.0 \mathrm{~K}_{\mathrm{D}}$ was assumed. As noted in Butler (1998), this is the recommended value to use for slug-test analysis when setting the aquifer thickness to the well-screen length. Previous investigations by the main author have indicated that single-well slug-test responses are relatively insensitive to $\mathrm{K}_{\mathrm{D}}$; therefore, the use of an assumed (constant) value of 1.0 over a small well-screen section (i.e., $<10 \mathrm{~m}$ long) is not expected to have a significant impact on the determination of hydraulic conductivity, $K_{h}$, from the type-curve-matching analysis.

To facilitate the unconfined aquifer slug-test type-curve analysis, an $S_{\mathrm{s}}$ value of $0.00001 \mathrm{~m}^{-1}$ was used for all initial analysis runs. After initial matches were made through adjustments of transmissivity, $\mathrm{T}$, additional adjustments of $S_{\mathrm{s}}$ were then attempted to improve the overall match of the test-response pattern. In most test cases, slight modifications (i.e., increasing $S_{\mathrm{s}}$ ) were made to the input $S_{\mathrm{s}}$ values to improve the final analysis type-curve matches. However, other factors influence the shape of the slug-test curve (e.g., skin effects, $K_{D}$ ). For this reason, the $S_{s}$ estimate obtained from the final slug-test analyses is considered to be of only qualitative value and should not be used (as in the case for $\mathrm{K}_{\mathrm{h}}$ ) for quantitative applications.

For the slug-test analysis, the well-screen interval below the water table (rather than the sandpack interval) was used to represent the test interval. This was based on the assumption that the formation materials within the screened interval have a higher permeability than the sandpack; therefore, testresponse transmission is expected to propagate faster laterally from the well screen to the surrounding test formation than vertically within the sandpack zone. In reality, only small differences exist between individual well-screen and sandpack-interval lengths (i.e., compared to the aquifer-thickness relationship) and, subsequently, no significant differences in analysis results would be expected. This assumption is consistent with recommendations listed in Butler (1996).

The type-curves analyses presented in this report were generated using the KGS program described in Liu and Butler (1995). The KGS program is not strictly valid for the boundary condition, where the water table occurs within the well screen. However, a comparison of slug-test type curves generated from converted pumping test type curves (as described in Spane 1996), which accounts for this boundary 
effect, indicates very little difference in predicted responses when compared to the KGS model results. Because of this close comparison and the fact that the KGS program calculates slug-test responses directly and can be applied more readily for analysis of the slug-test results, it was used as the primary type-curve-analysis method in this report.

\subsubsection{Heterogeneous Formation Analysis}

Inherent in the analytical methods discussed above is the assumption that the test interval is homogeneous. A number of formation heterogeneities, however, can exert significant influence on slug test response. Recognized heterogeneous formation conditions affecting slug test response include multilayers of varying hydraulic properties within the well-screen section, presence of linear boundaries, and radial variation of hydraulic properties with distance from the well (i.e., radial boundaries).

The effects of multi-layer conditions within the test interval have been examined previously by Butler et al. (1994) and Butler (1998). These studies indicate that the presence of multi-layers of varying hydraulic properties cannot be distinguished from the pattern of the slug test response. For well screens that fully penetrate a heterogeneous, multi-layer aquifer, the hydraulic conductivity estimated from the slug test will be an arithmetic average of the thickness-weighted $\mathrm{K}_{\mathrm{h}}$ values of the individual layers. For well screens that partially penetrate the upper-part of a multi-layer aquifer, the hydraulic conductivity estimated from the test also will represent a thickness-weighted arithmetic average, as long as significant vertical leakage does not occur from layers underlying the test interval.

The effects of linear boundaries on slug test response have been examined previously by Karasaki et al. (1988), and Guyonnet et al. (1993). These effects are largely dependent on the nature of the boundary (i.e., no-flow or constant-head), proximity to the test well, and the storage characteristics of the aquifer and well. As a generalization, Guyonnet et al. (1993) state that no-flow boundaries cause the slug test response to deviate from and delay recovery, while constant-head boundaries cause the slug test to recover faster than that predicted for a corresponding unbounded system response. Karasaki et al. (1988) accounts for the presence of linear boundaries within slug test response by employing image-well theory. The effect of linear boundaries is very similar to that imposed by radial boundaries, which is discussed in the following paragraphs.

The effects of radial variations of hydraulic properties surrounding the test well have been investigated previously in studies examining slug tests in the presence of finite-thickness skin (e.g., Moench and Hsieh 1985). A finite-thickness skin is essentially a radial boundary condition surrounding a fullypenetrating well, where the inner zone has significantly different hydraulic properties than the outside zone. A negative skin refers to the case where $\mathrm{K}_{\mathrm{h}}$ of the inner zone is much greater than that of the outer zone (i.e., $\mathrm{K}_{1}>>\mathrm{K}_{2}$ ); while a positive skin denotes the opposite condition (i.e., $\mathrm{K}_{1}<<\mathrm{K}_{2}$ ). The effects of a radial boundary on slug test response are largely a function of the contrast in $\mathrm{K}_{\mathrm{h}}$ for the inner and outer zone, the storage characteristics, and radial distance from the well to the boundary.

Figure 3.2 shows the slug test responses for a negative finite-thickness skin condition, where the inner zone has a $\mathrm{K}_{\mathrm{h}} 100$ times greater than the outer zone, for various selected radial boundary distances $(0.5$, 1.0, $2.0 \mathrm{~m}$ ). The test responses were generated using the KGS program referenced in Section 3.1.2, which 


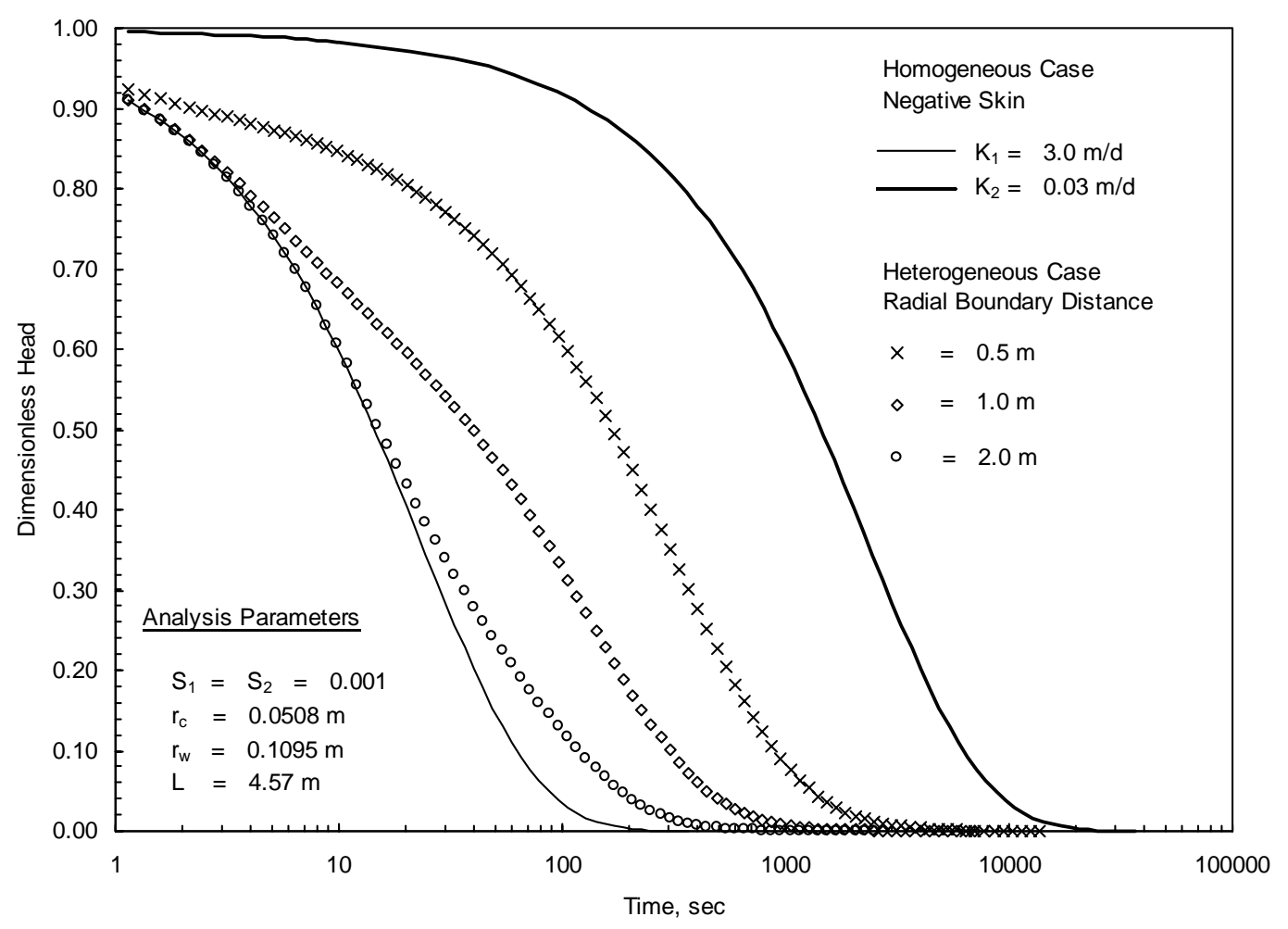

Figure 3.2. Predicted Slug Test Response: Negative Finite-Thickness Skin Conditions

can account for finite-thickness well-skin conditions. For comparison purposes, homogeneous slug test responses (i.e., no radial boundary) for the $\mathrm{K}_{\mathrm{h}}$ representative solely of the inner and outer zones are also provided. For this example, the storativities, $\mathrm{S}$, for both zones are set equal and representative of elastic formation conditions $\left(S_{1}=S_{2}=0.001\right)$. An examination of Figure 3.2 indicates several important features. During early-test times, all the radial boundary examples follow the inner zone response (i.e., homogeneous formation response), with the duration of coincidence being directly associated with distance to the radial boundary. The presence of the radial boundary is exhibited by the departure from inner zone response, where the test response becomes flatter (recovery rate decreases) and transitions to a combined composite test response, reflective of the hydraulic properties inside and outside the radial boundary. Recognizing whether radial flow boundaries are present within the slug test response may be difficult unless the transition period segments of the test are distinct. Recognizing the presence of radial boundaries, however, is more apparent when slug test derivative plots are employed.

Figure 3.3 shows the derivative slug test responses for the same test conditions presented in Figure 3.2. As shown, radial boundaries for the distances greater than $0.5 \mathrm{~m}$ are denoted by a derivative pattern exhibiting multiple peaks or a stair-step pattern, which is in contrast to the smooth, single peak derivative pattern exhibited by homogeneous formations. For radial distances extremely close (e.g., $<0.5 \mathrm{~m}$ ) or far (e.g., $>5.0 \mathrm{~m}$ ) from the test well, the presence of boundaries may not be detected within the test response. 


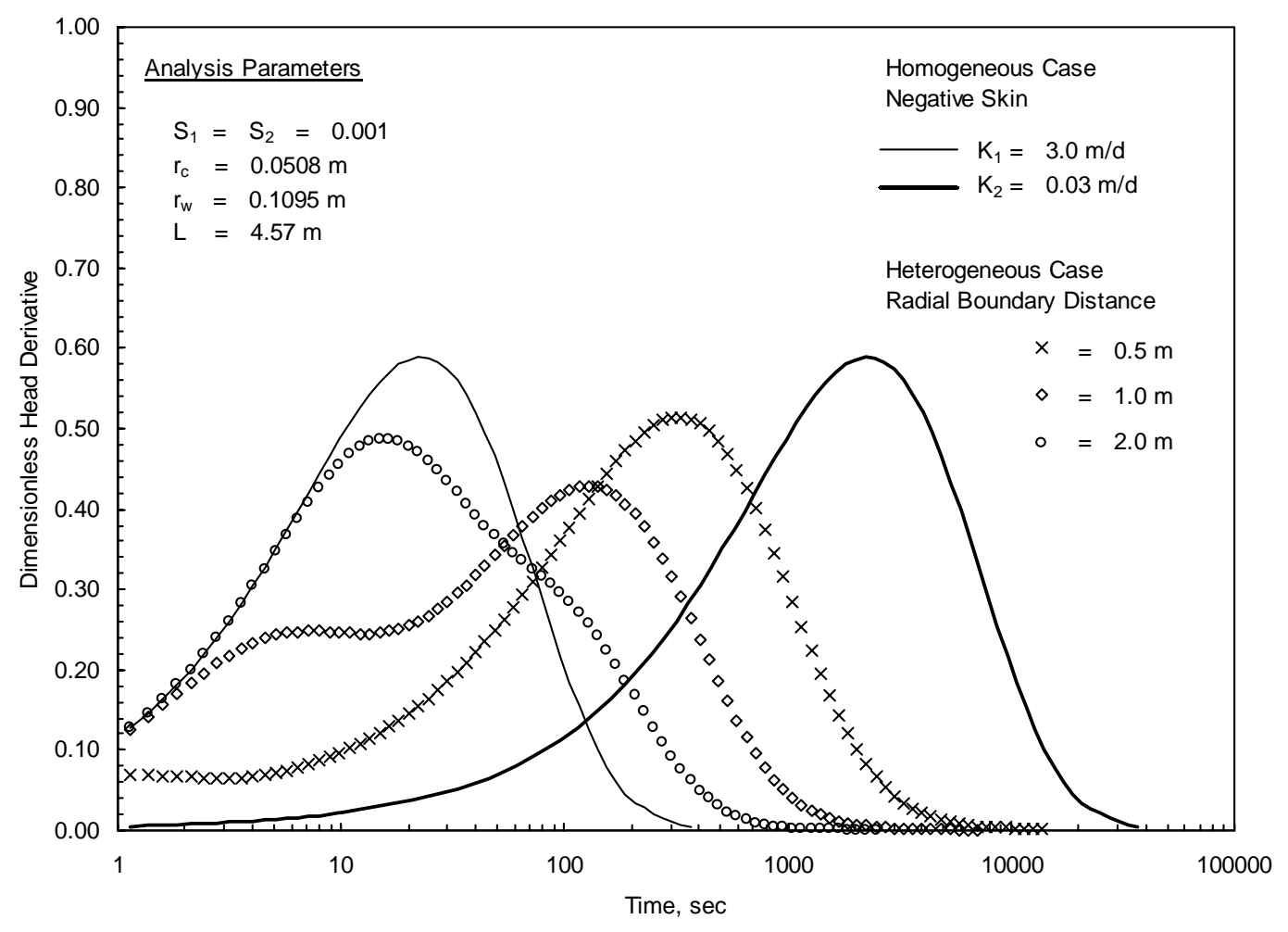

Figure 3.3. Predicted Slug Test Derivative Response: Negative Finite-Thickness Skin Conditions

Figure 3.4 shows the slug test responses for a positive finite-thickness skin condition, where the inner zone has a $\mathrm{K}_{\mathrm{h}} 0.01$ times that of the outer zone, for the same selected radial boundary distances $(0.5,1.0$, $2.0 \mathrm{~m}$ ) and test conditions examined for the negative skin case (only the $\mathrm{K}_{\mathrm{h}}$ values for the inner and outer zones are reversed). As for the previous negative-skin example, during early-test times, the various heterogeneous responses follow the inner zone response (i.e., homogeneous formation response), with the duration of coincidence being directly associated with distance to the radial boundary. The presence of the radial boundary is exhibited by the departure from inner zone response, where the test response becomes steeper (recovery rate increases), with test recovery becoming reflective of a combined composite test response reflective of the hydraulic properties inside and outside the radial boundary. The increased steepness in test response due to the presence of a radial boundary (positive-skin), becomes more apparent when type-curve analysis methods are used (i.e., in comparison to the Bouwer and Rice method). As discussed in Butler (1998), the analysis of slug tests affected by positive-skin conditions often requires use of homogeneous formation type curves with unrealistically low storativity values. For this reason, Butler (1998) recommends the use of type-curve analysis for slug tests to detect whether positive skin-radial boundaries are present within the test response.

Three of the wells tested during FY 2000 exhibited effects of heterogeneous formation - radial boundary conditions and were analyzed using the KGS program for complete test response analysis (i.e., $\mathrm{K}_{\mathrm{h}}$ of the inner and outer zones). These analysis results are discussed in Section 4.0. 


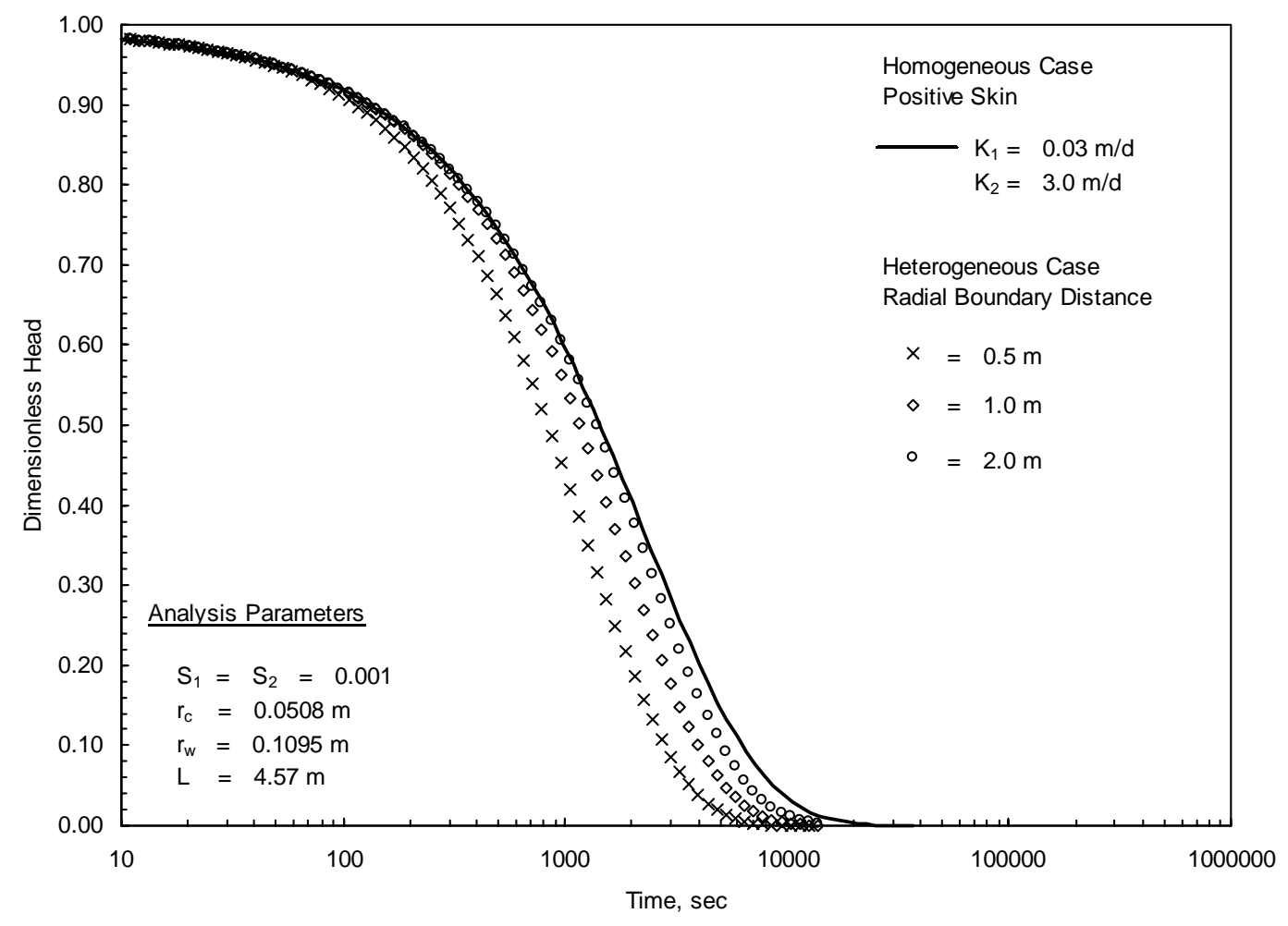

Figure 3.4. Predicted Slug Test Response: Positive Finite-Thickness Skin Conditions

\subsection{Single-Well Tracer Tests}

Single-well tracer tests can provide information on groundwater-flow characteristics (e.g., flow velocity) and aquifer properties (i.e., vertical distribution of $\mathrm{K}$, effective porosity, $\mathrm{n}_{\mathrm{e}}$ ). During FY 2000, single-well tracer tests included tracer-dilution, tracer-pumpback, and in-well vertical flow tracer. Performance and analysis methods for the various single-well tracer tests are described below.

\subsubsection{Tracer-Dilution Tests}

For the tracer-dilution test, a bromide solution of known concentration was mixed within the wellscreen section. The decline of tracer concentration (i.e., "dilution") with time within the well screen was monitored directly using a vertical array of bromide-specific ion-electrode sensors located at known depth intervals. The sensors were calibrated in the laboratory with standards of known bromide concentration prior to and following performance of the tracer-dilution test. Based on the dilution characteristics observed, the vertical distribution (i.e., heterogeneity) of hydraulic properties and/or in-well flow velocity can be estimated for the formation section penetrated by the well screen. The presence of vertical flow within the well screen can also be identified from the sensor/depth-dilution-response pattern. A description of the performance and analysis of tracer-dilution test characterization investigations is provided in Halevy et al. (1966), Hall et al. (1991), and Hall (1993). 
Essential design elements of a tracer-dilution test include establishing a known, constant tracer concentration within the test section by mixing or circulating the tracer solution in the wellbore/test interval and monitoring the decline of tracer concentration with time within the test interval.

The decline in tracer concentration within the wellbore can be analyzed to ascertain the hydraulic gradient, I (if the formation's K is known) or the test-interval K (if the hydraulic gradient is known) using the following analytical expression:

$$
\ln \left(\mathrm{C} / \mathrm{C}_{\mathrm{o}}\right)=-\left(\mathrm{Q}_{\mathrm{w}} \mathrm{t}\right) / \mathrm{V}
$$

where $\quad \mathrm{C}=$ concentration of the tracer in the test interval at time, $\mathrm{t}$

$\mathrm{C}_{\mathrm{o}}=$ initial concentration of the tracer at the start of the test

$\mathrm{Q}_{\mathrm{w}}=$ in-well, lateral groundwater discharge within the well-test interval

$\mathrm{V}=$ isolated test interval well volume.

For test-analysis purposes, Equation (3.2) is commonly rewritten to calculate the groundwater-flow velocity within the well, $\mathrm{v}_{\mathrm{w}}$, as follows:

$$
\mathrm{v}_{\mathrm{w}}=\mathrm{d}(\ln \mathrm{C}) / \mathrm{dt} /(-\mathrm{A} / \mathrm{V})
$$

where $\quad \mathrm{A}=$ cross-sectional area within well screen; $\mathrm{L}^{2}$

$\mathrm{V}=$ well volume over measurement section; $\mathrm{L}^{3}$.

As shown by Halevy et al. (1966) to take into account the cross-sectional/well-measurement volume effects of the emplaced in-well tracer-measurement system (downhole probe, cables), Equation (3.3) can be rewritten as

$$
\mathrm{v}_{\mathrm{w}}=\mathrm{d}(\ln \mathrm{C}) / \mathrm{dt} /-\left[2 \mathrm{r}_{\mathrm{w}} / \pi\left(\mathrm{r}_{\mathrm{w}}^{2}-\mathrm{r}_{\mathrm{t}}^{2}\right)\right]
$$

where $\quad r_{w}=$ radius of well screen; $L$

$r_{t}=$ equivalent radius of tracer-measurement system; $L$.

It should be noted that the calculated $\mathrm{v}_{\mathrm{w}}$ is not the groundwater-flow velocity within the aquifer, $\mathrm{v}_{\mathrm{a}}$. The $\mathrm{v}_{\mathrm{w}}$ is related to actual groundwater velocity within the aquifer by the following relationship:

$$
\mathrm{v}_{\mathrm{w}}=\mathrm{v}_{\mathrm{a}} \mathrm{n}_{\mathrm{e}} \propto
$$

where $\quad \mathrm{n}_{\mathrm{e}}=$ effective porosity; dimensionless

$\propto=$ groundwater-flow-distortion factor; dimensionless, common range 0.5 to 4 . 
Various aspects of conducting tracer-dilution tests (i.e., test design, influencing factors) have been previously discussed by a number of investigators (e.g., Halevy et al. 1966; Freeze and Cherry 1979). Following completion of the tracer-dilution test, the tracer can be recovered from the formation by pumping, and the results analyzed to assess the effective porosity within the test interval. Tracer-pumpback tests are discussed in the following section.

Some investigators have noted differences in hydraulic property estimates obtained with tracerdilution techniques and other test methods (e.g., Drost et al. 1968; Kearl et al. 1988). These differences were attributed, in some cases, to distortions in the flow field caused by increased (or decreased) permeability near the well.

Analysis details and results for tracer-dilution tests conducted at each of the selected test wells during FY 2000 are provided in Section 5.0.

\subsubsection{Tracer-Pumpback Tests}

Detailed procedures for conducting standard, single-well, conservative tracer tests are provided in Pickens and Grisak (1981) and Molz et al. (1985). The tracer pumpback includes the following basic test procedure:

- emplace a conservative tracer (bromide) within the well/aquifer system

- define a prescribed residence (drift) time for the tracer to be dispersed within the aquifer

- withdraw the tracer from the well/aquifer system by pumping at a constant rate

- monitor tracer concentrations at the test well (bromide sensor/flow cell) and collect discrete groundwater samples for quantitative laboratory analysis.

The tracer-testing program relied on natural groundwater flow to emplace the tracer and did not include actual "injection" of the bromide tracer into the surrounding aquifer. Because of the relatively small area represented by the well (i.e., in comparison to the aquifer) and volumes of tracer involved, the results obtained from these tracer tests may be more susceptible to wellbore effects (e.g., $\propto$ and possible downgradient dead zone).

For the tracer-pumpback tests, a constant-rate pumping test is initiated after the average tracer concentration had decreased (i.e., diluted) to a sufficient level within the well screen (usually a one- to two-order of magnitude reduction from the original tracer concentration). The objective of the pumpback test is to "capture" the tracer that has moved from the well into the surrounding aquifer. Tracer recovery is monitored qualitatively by measuring the tracer concentration at the surface using a bromide sensor/ flow cell installed in the discharge line. Discrete samples are collected at the surface at preselected times for quantitative laboratory tracer analysis. 
The time required to recover the center of tracer mass from the aquifer provides information concerning $\mathrm{n}_{\mathrm{e}}$ and $\mathrm{v}_{\mathrm{a}}$. $\mathrm{n}_{\mathrm{e}}$ is a primary hydrologic parameter that controls contaminant transport. Analytical methods available for the analysis of single-well, tracer injection/withdrawal tests include (in addition to the previously cited references) Güven et al. (1985), Leap and Kaplan (1988), and Hall et al. (1991). The procedure to analyze the tracer-pumpback results is based on a rearrangement of the equations presented in Hall et al. (1991), which combines the basic pore velocity groundwater-flow equation (Equation [3.6]) with the regional advective flow-velocity equation (Equation [3.7]) describing tracer-drift and -pumpback tests as reported in Leap and Kaplan (1988).

$$
\begin{gathered}
\mathrm{v}_{\mathrm{a}}=(\mathrm{K} \mathrm{I}) / \mathrm{n}_{\mathrm{e}} \\
\left.\mathrm{v}_{\mathrm{a}}=\left[\left(\mathrm{Qt}_{\mathrm{p}}\right) / \pi \mathrm{n}_{\mathrm{e}} \mathrm{b}\right)\right]^{1 / 2} / \mathrm{t}_{\mathrm{t}}
\end{gathered}
$$

Combining and rearranging results in

$$
\mathrm{v}_{\mathrm{a}}=\left(\mathrm{Q} \mathrm{t}_{\mathrm{p}}\right) /\left(\pi \mathrm{b} \mathrm{t}_{\mathrm{t}}^{2} \mathrm{~K} \mathrm{I}\right)
$$

and

$$
\mathrm{n}_{\mathrm{e}}=\left(\pi b \mathrm{t}_{\mathrm{t}}^{2} \mathrm{~K}^{2} \mathrm{I}^{2}\right) /\left(\mathrm{Q} \mathrm{t}_{\mathrm{p}}\right)
$$

where $\quad \mathrm{v}_{\mathrm{a}}=$ advective groundwater-flow velocity within the aquifer; $\mathrm{L} / \mathrm{T}$

$\mathrm{n}_{\mathrm{e}}=$ effective porosity; dimensionless

$\mathrm{K}=$ hydraulic conductivity; $\mathrm{L} / \mathrm{T}$

$\mathrm{I}=$ local hydraulic gradient; dimensionless

$\mathrm{b}=$ aquifer thickness; $\mathrm{L}$

$\mathrm{Q}=$ tracer-pumpback rate; $\mathrm{L}^{3} / \mathrm{T}$

$t_{p}=$ pumping time required to recover the center of mass of tracer emplaced into the aquifer

$t_{t}=$ total elapsed time equal to sum of the tracer drift time, $t_{d}$, (time from tracer emplacement to start of recovery pumping) and $t_{p}$.

The K values used in Equations (3.8) and (3.9) were determined from analysis of constant-rate pumping tests for the test well (i.e., during the tracer pumpback). The I value was determined using trendsurface analysis of water-level elevation measurements from nearby wells as described in Section 3.4. The $b$ value was calculated directly from geologic information obtained for the well or projection from known geologic relationships at nearby wells.

To calculate the time required to recover the tracer center of mass emplaced into the aquifer, several steps were required. The bromide concentration versus time profile during the pumpback test was determined by laboratory analysis of discrete samples collected closely over time. The mass of tracer recovered with time was calculated, based on integrating the product of the exhibited tracer concentration profile and observed pumping rate during the test. The $t_{p}$ value, to the center of mass, was calculated by dividing the tracer mass recovered by the actual tracer mass transported into the aquifer. To calculate the 
actual tracer mass within the aquifer, the mass within the well-screen column and surrounding well sandpack at the start of the pumpback test was subtracted from the initial mass emplaced in the well. The mass within the well screen was determined by multiplying the known well-screen volume by the average concentration, which was calculated by the final readings of the bromide sensors used during the tracerdilution test. The sensors were removed generally within 2 hours of initiation of the tracer pumpback; therefore, their final readings are representative of initial pumpback conditions. For calculating the tracer mass within the sandpack, the study assumed that the tracer concentration was the same as observed within the well screen. Sandpack volumetric calculations were based on available as-built information, a porosity of $25 \%$, and the assumption that $50 \%$ of the sandpack (i.e., the downgradient side) would be occupied by tracer.

The mathematical relationship to calculate half the tracer mass recovered during the pumpback, $\mathrm{M}_{50 \% \text {, }}$ which is the mass used to calculate the center of mass recovery time, $t_{\mathrm{p}}$, then can be expressed as:

$$
\mathrm{M}_{50 \%}=0.50\left(\mathrm{M}_{\mathrm{r}}-\mathrm{M}_{\mathrm{w}}\right) /\left(\mathrm{M}_{\mathrm{i}}-\mathrm{M}_{\mathrm{w}}\right)
$$

where $\mathrm{M}_{\mathrm{r}}=$ mass of tracer recovered during the tracer pumpback; $\mathrm{M}$

$\mathrm{M}_{\mathrm{w}}=$ mass of tracer within well screen and well sandpack at the beginning of the tracer pumpback; $\mathrm{M}$

$\mathrm{M}_{\mathrm{i}}=$ mass of tracer initially emplaced in the well; $\mathrm{M}$.

The $t_{p}$ also was corrected (reduced) to account for the transit time of the pumped water from the pump intake to land surface (i.e., location where laboratory samples were collected).

Analysis details and results for tracer-pumpback tests conducted at each of the selected test wells are provided in Section 6.0.

\subsubsection{In-Well, Vertical Flow Tests}

As discussed in Section 3.2.1, the successful performance of tracer-dilution tests requires that lateral groundwater-flow conditions exist within the well fluid column. The presence of vertical flow is indicated during the initial phases of tracer dilution if a systematic, "stair-step," tracer-dilution pattern is exhibited for the respective depth settings of the bromide sensor. Figure 3.5 illustrates a hypothetical tracer-dilution pattern for various depths for a downward vertical flow condition within the well screen. As shown, the pattern evolves with time (after the tracer has been uniformly mixed within the well-screen section) as a result of the downward flow/mixing of nontracer groundwater. As shown in Figure 3.5, the pattern is characterized by a progressive extension of a constant tracer concentration for the sensors at greater depths, followed by a rapid decline of tracer on arrival of the downward flow mixture of tracer and nontracer groundwater. During late-test times, the various tracer versus depth profiles exhibit a parallel-linear pattern. $\mathrm{v}_{\mathrm{w}}$ can be calculated by using the arrival time of the tracer/nontracer groundwater mixture front at the various known depth/sensor spacings. 


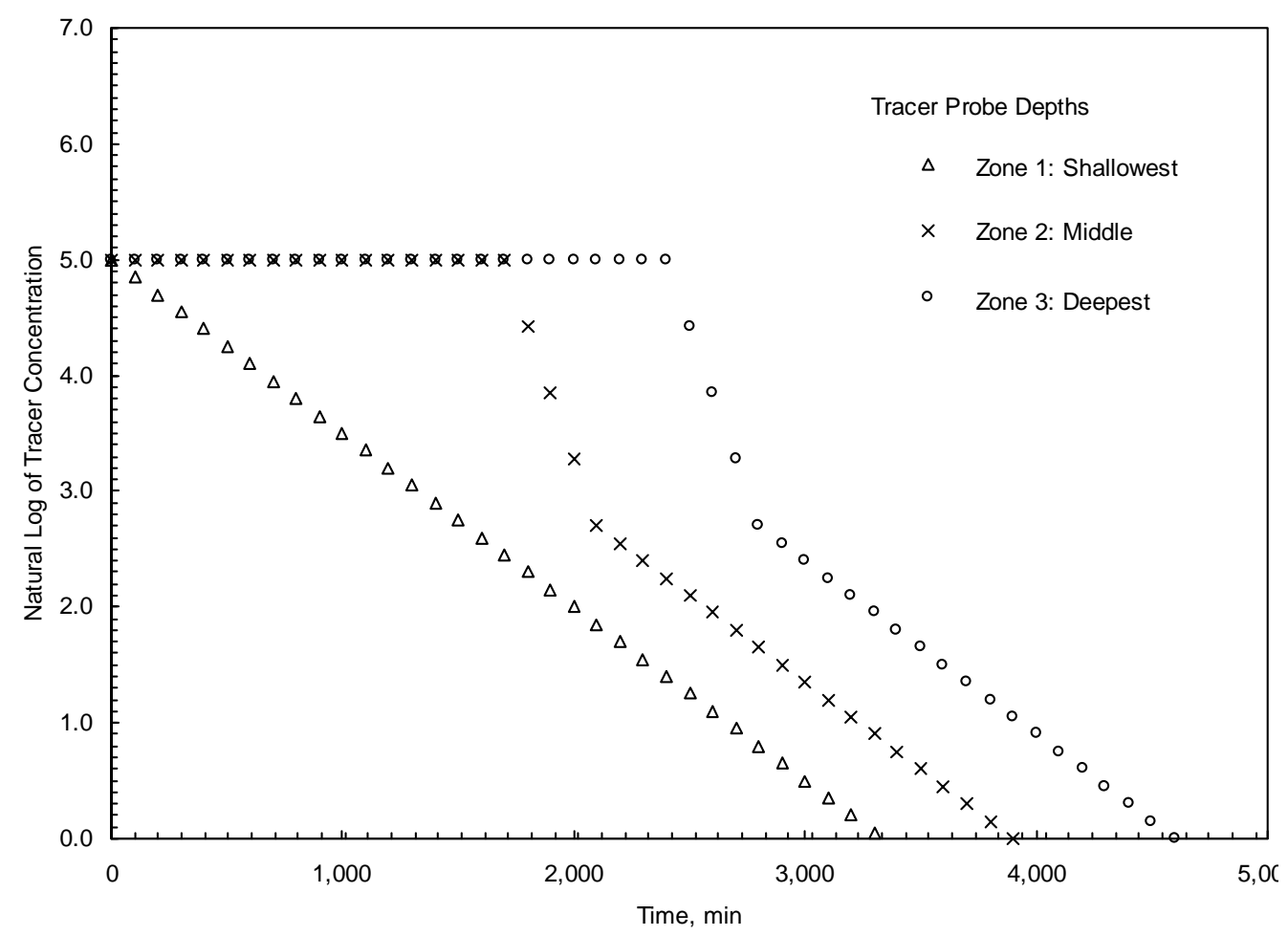

Figure 3.5. Hypothetical Tracer-Dilution Pattern Indicative of Vertical, In-Well, Downward Flow

For well sites exhibiting in-well vertical flow conditions during tracer-dilution testing, follow-up in-well vertical flow tracer tests were conducted. For indicated downward vertical flow conditions, a bromide tracer solution slug was introduced within the upper or lower $1.0 \mathrm{~m}$ of the well fluid column (i.e., for suspected downward or upward vertical flow conditions). The solution contained sufficient mass to create a concentration of $\leq 50 \mathrm{mg} / \mathrm{L}$ within the well column. A low concentration was employed in most tests to minimize possible tracer-density effects within the well column. The tracer was introduced to the well by a 0.003 -m-inner-diameter tubing that was attached directly to the sensor assembly installed in the well. The sensor array was designed with fixed-distance spacings (i.e., $0.91 \mathrm{~m}$ ). Measurement of the arrival peaks of the tracer solution at the various known depth/distance sensor spacings provided the means of calculating the vertical downward flow velocity for individual tracer depths within the well. The tracer peak arrival method was used to provide a range of in-well vertical flow velocities. The average vertical flow velocity was calculated by determining the depth to the center of tracer mass within the well for selected test times. The slope of the linear regression of time versus the center of tracer mass provides the estimate of average in-well vertical flow. Similar in-well vertical flow tracer tests that have used the tracer peak arrival and center of mass analysis methods are presented in Michalski (1989) and Michalski and Klepp (1990).

As a third method, in-well vertical flow velocity was measured directly for the indicated well sites using an electromagnetic borehole (EM) flow meter. The EM flow-meter system is highly sensitive for measurement of low, in-well, vertical flow under either static or dynamic (pumping test) conditions. Its low-flow-detection capability is superior to commercially available mechanical and heat-pulse flow-meter 
systems. As described in Waldrop and Pearson (2000), the EM flow meter consists of an electromagnet and two electrodes located at 180 degrees apart and 90 degrees to the magnetic field within a hollow, flow-through cylinder. Flow measurement is based on Faraday's law of induction, which states that the voltage induced by a conductor moving at right angles through a magnetic field is directly proportional to the velocity of the conductor through the field. The flowing water within the well is the conductor, the electromagnet generates the magnetic field, and the electrodes measure the induced voltage. Subsurface electronics attached to the electrodes transmit the measured voltage to the recording system, which converts the observed voltage to a calculated vertical flow velocity. A more detailed description of the EM system and results from the in-well vertical flow surveys are presented in Waldrop and Pearson (2000). Analysis details and results for in-well vertical flow tests conducted at each of the selected test wells are provided in Section 8.0.

\subsection{Constant-Rate Pumping Tests}

Drawdown and recovery water levels were measured during tracer-pumpback tests at each of the five RCRA wells selected for detailed hydrologic characterization (299-W15-41, 299-W22-48, 299-W22-49, 299-W22-50, and 699-43-44). Water levels also were recorded at a nearby observation well (299-W2239) during testing at well 299-W22-49. Diagnostic analysis of the test responses was first conducted to determine test system characteristics and to identify test data that display infinite-acting radial flow behavior. Analysis of the drawdown and recovery phases of constant-rate discharge were then performed by type-curve fitting of log-log plots and, if appropriate, by straight-line analysis of semilogarithmic data plots of water-level change versus time. Test performance and methods used to analyze the results obtained from constant-rate testing are described in this section. Analysis details and results for each of the selected test wells are provided in Section 7.0.

\subsubsection{Test Methods and Equipment}

A 3-hp Grundfos ${ }^{\circledR}$ submersible pump was used to remove water during each pumping test. Flow rates were monitored with a surface turbine flow meter (inside diameter $0.025 \mathrm{~m}, \mathrm{Arad}^{\circledR}$, model \#555061). Flow was adjusted manually using a gate valve to maintain constant-rate conditions. During the initial minutes of pumping (e.g., first 5 minutes), "instantaneous" flow rates were determined by measuring the time required for $19 \mathrm{~L}$ of flow to register on the flow-meter dials. Flow-meter totalizer readings were recorded every 5 to 20 minutes during pumping. Druck, Inc., 0- to 10-psig, differential pressure transducers (model \# PDCR ${ }^{\circledR} 1830-8388$ ) were used to monitor water levels in the pumping well and the nearby monitor wells during the test. The transducers were vented at the surface to compensate automatically for atmospheric pressure fluctuations. Pressure transducer measurements were recorded using a Campbell Scientific, Inc. model CR-10X ${ }^{\mathrm{TM}}$ data logger.

Because tracer recovery also was being monitored during the tracer-pumpback test, part of the discharged groundwater was routed through a flow-through cell containing a bromide-selective ion probe, and a sampling port was used to collect water for laboratory analysis of the bromide tracer. These devices were downstream from the flow meter. The discharged water during the pumping test was collected in a tank truck for subsequent disposal at an effluent disposal facility. 


\subsubsection{Barometric Pressure Effects Removal}

The analysis of well water-level responses during hydrologic tests provides the basis to estimate hydraulic properties that are important to evaluate groundwater-flow velocity and transport characteristics. Barometric pressure fluctuations, however, can have a discernible impact on well water-level measurements. Although the pressure transducers were vented to compensate for changes in barometric pressure, barometric pressure fluctuations also can cause changes in the water level in a well. This response effect is commonly ascribed to confined aquifers; however, wells completed within unconfined aquifers may also exhibit associated responses to barometric changes (Weeks 1979; Rasmussen and Crawford 1997). Water levels in unconfined aquifers typically exhibit variable time-lagged responses to barometric fluctuations. This time-lag response is caused by the time required for the barometric pressure change to be transmitted to the water table through the vadose zone compared to the instantaneous transmission of barometric pressure through the open well.

To determine the significance of barometric effects, water-level changes were monitored during a baseline period before or after each constant-rate discharge test and compared to the corresponding barometric pressure changes. Barometric pressures were obtained from the Hanford Meteorology Station (located immediately east of the 200-West Area), where they are recorded hourly. The barometric responses were then analyzed and removed from the recorded water levels using the multiple-regression deconvolution techniques described in Rasmussen and Crawford (1997) and Spane (1999). This technique relies on a least-squares fit of the water-level change to the corresponding barometric pressure change and time-lagged earlier barometric pressure changes. As noted in Spane (1999), under prevalent conditions in the 200-West and East Areas, no significant difference in removal efficiency was derived in using data collected at higher recording frequencies (e.g., 10 minutes). Therefore data collected at a 1-hour frequency were utilized in the process for barometric pressure removal.

Because barometric changes were recorded at a constant 1-hour frequency, the relationship between water-level and barometric change can be represented as follows:

$$
\Delta \mathrm{h}_{\mathrm{w}}=\mathrm{X}_{0} \Delta \mathrm{h}_{\mathrm{ai}}+\mathrm{X}_{1} \Delta \mathrm{h}_{\mathrm{ai}-1}+\mathrm{X}_{2} \Delta \mathrm{h}_{\mathrm{ai}-2}+\ldots+\mathrm{X}_{\mathrm{n}} \Delta \mathrm{h}_{\mathrm{ai}-\mathrm{n}}
$$

where $\quad \Delta \mathrm{h}_{\mathrm{w}}=$ water-level change over the last hour

$\Delta \mathrm{h}_{\mathrm{ai}}=$ barometric pressure change over the last hour

$\Delta \mathrm{h}_{\mathrm{a}-1}=$ barometric pressure change from 2 hours to 1 hour previous

$\Delta \mathrm{h}_{\mathrm{ai}-\mathrm{n}}=$ barometric pressure change from $\mathrm{n}$ hours to ( $\left.\mathrm{n}-1\right)$ hour previous

$\mathrm{X}_{0} \ldots \mathrm{X}_{\mathrm{n}}=$ regression coefficients corresponding to time lags of 0 to $\mathrm{n}$ hours

$\mathrm{n}=$ number of hours that lagged barometric effects are apparent.

After calculating $\mathrm{X}_{0} \ldots \mathrm{X}_{\mathrm{n}}$, simulated well water levels associated with the hourly barometric responses were calculated from the above equation for the baseline period. The results were then compared to the actual observed well water-level response for a "goodness of fit" evaluation. To remove barometric effects from water levels recorded during the constant-rate discharge test, a simulated well water-level response was calculated based on the hourly barometric changes that were observed over the 
test period. The predicted barometric induced response was then subtracted from the recorded pumping test water-level measurements. Analysis techniques described in the following section were then applied to the data after removal of barometric effects.

\subsubsection{Diagnostic Analysis and Derivative Plots}

Log-log plots of water level versus time have traditionally been used for diagnostic purposes to examine pumping test drawdown data. More recently, the derivative of the water level or pressure has also been used (Bourdet et al. 1989; Spane 1993) as a diagnostic tool. Use of derivatives has been shown to improve significantly the diagnostic and quantitative analysis of various hydrologic test methods (Bourdet et al. 1989; Spane 1993). The improvement in test analysis is attributed to the sensitivity of pressure derivatives to various test/formation conditions. Specific applications for which derivatives are particularly useful include the following:

- determining formation-response characteristics (confined or unconfined aquifer) and boundary conditions (impermeable or constant head) that are evident within the test data

- assisting in the selection of the appropriate type-curve solution through combined type-curve/ derivative plot matching

- determining when infinite-acting, radial flow conditions are established and, therefore, when straightline analysis methods are applicable.

Figure 3.6 shows log-log drawdown and derivative responses that are characteristic of some commonly encountered formation conditions. The early data, occurring before the straight-line approximation is valid or where wellbore storage is dominant, produce a steep, upward-trending derivative. The derivative normally decreases during transition from wellbore storage to radial flow and stabilizes at a constant value when infinite-acting, radial flow conditions are established. The stable derivative reflects the straight line on the semilog plot for infinite-acting radial flow. Unconfined aquifers and formations exhibiting double-porosity characteristics (e.g., fractured media) may show two stable derivative sections at the same vertical position separated by a "valley" that represents the transition from one storage value to the other. Diagnostic derivative plots are also useful to identify boundary effects.

A linear, no-flow boundary will result in a doubling of the magnitude of the derivative. If radial flow is established before the influence of the boundary is seen, a stable derivative will occur for a time followed by an upward shift to twice the original value. Constant-head boundaries display a downward trend in the derivative, which may be preceded by a stable derivative if radial flow conditions occur before the boundary effect becomes dominant. For the diagnostic and test analysis aspects of this report, derivative responses were calculated using the DERIV program described in Spane and Wurstner (1993). 


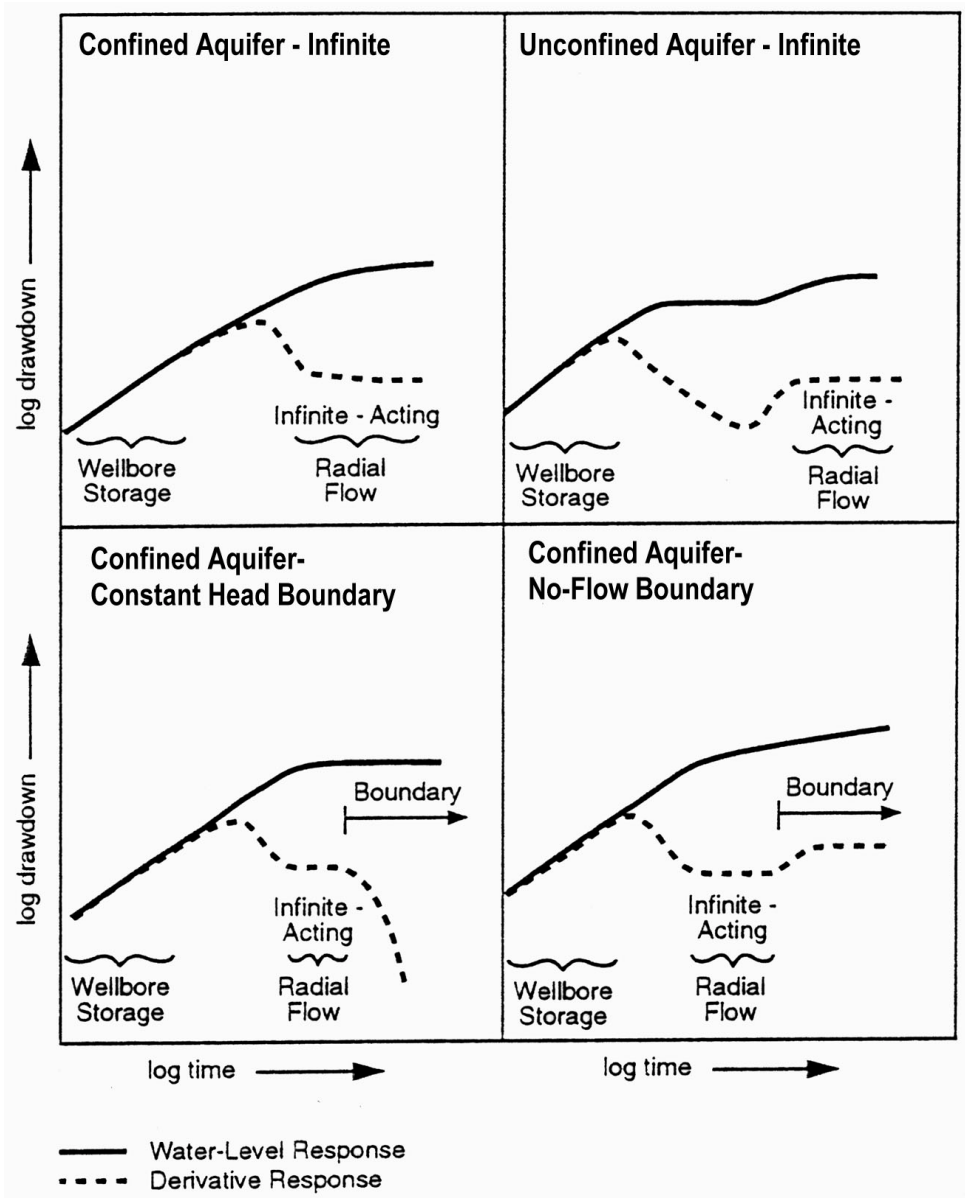

Figure 3.6. Characteristic Log-Log Drawdown and Drawdown Derivative Plots for Various Hydrogeologic Formation and Boundary Conditions

For pumping tests conducted as part of the FY 2000 detailed hydrologic characterization tests, the derivative of the water level with respect to the natural logarithm of time (i.e., essentially the slope of the semilog plot) was calculated and plotted on the log-log plots of drawdown versus time. For recovery data, the "Agarwal equivalent time function" (Agarwal 1980) was used in calculating the derivative and plotting recovery data. This time function accounts for the effects of the pumping period through a superposition technique. Diagnostic and analysis results of the log-log plots of water-level and associated derivative response for each well site constant-rate pumping test is provided in Section 7.0.

\subsubsection{Type-Curve-Matching Analysis Methods}

Type-curve-matching methods (Theis 1935; Hantush 1964; Neuman 1972, 1974, 1975) are commonly used in the analysis of pumping test responses. For this study, unconfined aquifer pumping test type curves were generated using the WTAQ3 computer program described by Moench (1997). WTAQ3 can be used to generate type curves that represent a wide range of test and aquifer conditions, including partially penetrating wells, confined or unconfined aquifer models, well-skin effects, and wellbore storage 
at both the stress (pump) and observation (monitor) well locations. The type-curve-generation program also allows for noninstantaneous release (drainage-delay factor) of water from the unsaturated zone during the pumping test. However, this was found to not be a significant factor in the analysis; therefore, the type curves used in the analyses for this report all reflect an instantaneous release of water, which was the approach used by Neuman $(1972,1974,1975)$.

In the type-curve-matching procedure, the log-log drawdown or recovery data and its associated derivative response for an individual well were matched simultaneously with dimensionless type-curve responses generated using WTAQ3 (Moench 1997) and the associated derivative plots obtained with the DERIV program (Spane and Wurstner 1993). The dimensionless responses depend on the assumed values of sigma, $\sigma=\mathrm{S} / \mathrm{S}_{\mathrm{y}}$, and vertical anisotropy, $\mathrm{K}_{\mathrm{D}}=\mathrm{K}_{\mathrm{v}} / \mathrm{K}_{\mathrm{h}}$. For initial type-curve-matching runs, the values for $\sigma$ and $K_{D}$ were set at 0.001 and 0.10 , respectively. The predicted response also is influenced by the assumed storativity, $\mathrm{S}$, value because of its effect on wellbore storage. After an appropriate dimensionless match to the observed test data was obtained, dimensional curves were generated by using the given well/test conditions (e.g., well radius, radial distance to observation well, average pumping rate) and making adjustments to aquifer properties $\left(T, S_{y}\right)$ until the best match with the observed data was obtained. (Note that adjusting $S_{y}$ also changes the value of $S$ because $\sigma$ was held constant.)

Type-curve-matching methods are normally applied to observation well data and not to pumping wells because of the additional head losses that commonly occur at the pumped well. However, in analyzing the test responses for the new RCRA wells in the 200-West Area, the fitting of type curves to stress well responses resulted in approximately the same $\mathrm{T}$ as fitting type curves to the observation well data. This is probably an indication of the high efficiency of the stress well, which incorporates a screen and sand pack in a relatively low-permeability aquifer. Therefore, little head loss is associated with the movement of water into the well during pumping. Because of the lack of significant head loss, the simultaneous analysis of the observed drawdown or recovery response at the pumping well and observation well (i.e., composite plot analysis) could be demonstrated at most of the test sites for a uniform set of hydraulic properties.

\subsubsection{Straight-Line Analysis Methods}

For straight-line analysis methods, the rate of change of water levels within the well during drawdown and/or recovery is analyzed to estimate hydraulic properties. Because well effects are constant with time during constant-rate tests, straight-line methods can be used to analyze quantitatively the water-level response at both pumping and observation wells. The semilog, straight-line analysis techniques commonly used are based on either the Cooper and Jacob (1946) method (for drawdown analysis) or the Theis (1935) recovery method (for recovery analysis). These methods are theoretically restricted to the analysis of test responses from wells that fully penetrate nonleaky, homogeneous, isotropic, confined aquifers. Straight-line methods, however, may be applied under nonideal well and aquifer conditions if infiniteacting, radial flow conditions exist. Infinite-acting, radial flow conditions are indicated during testing when the change in pressure, at the point of observation, increases in proportion to the logarithm of time. As discussed above, the use of diagnostic derivative methods (Bourdet et al. 1989) makes it easier to identify the portions within the test data where straight-line analysis is appropriate. As will be discussed in Section 7.0, derivative analysis of the observed test responses indicated that radial flow conditions 
were not established at any of the selected observation well locations. Use of straight-line analysis methods, therefore, were not appropriate. The use of straight-line analysis methods is mentioned in this report, however, because they are common in the analysis of pumping test results.

\subsection{Groundwater-Flow Characterization}

To support the detailed hydrologic characterization program, groundwater-flow direction and hydraulic gradient conditions were calculated at the various test sites during the period of tracer testing. Groundwater-flow direction and hydraulic gradient were determined using the commercially available WATER-VEL (In-Situ, Inc. 1991) software program. Water-level elevations from neighboring, representative wells were used as input with the WATER-VEL program to calculate groundwater-flow direction and hydraulic gradient conditions. The program uses a linear, two-dimensional trend surface (least squares) to randomly located hydrologic head or water-level elevation input data. This method is similar also to the linear approximation technique described by Abriola and Pinder (1982) and Kelly and Bogardi (1989). Reports that demonstrate the use of the WATER-VEL program for calculation of groundwater-flow velocity and direction on the Hanford Site include Gilmore et al. (1992) and Spane (1999). Details and results for groundwater-flow characterization at four of the selected test wells are provided in Section 6.0. A summary of the results of groundwater-flow characterization is presented in Section 9.0. 


\subsection{Slug-Test Results}

Multiple slug tests were conducted at the 11 identified test wells during FY 2000. The slug tests were initiated by rapidly removing a slugging rod of known volume from the well-screen section. Two different size slugging rods were used during the testing program at each well to impose different stress levels on the test section. The stress levels for the two slugging rods are calculated to impose a slug-withdrawal test response of $0.458 \mathrm{~m}$ (low-stress tests) and $1.117 \mathrm{~m}$ (high-stress tests) within a $0.1016-\mathrm{m}$ inside diameter well. As noted in Butler (1996), differences exhibited between slug tests conducted at different stress levels can be used to evaluate stress-dependence effects of the well (e.g., dynamic skin, well development), which are unrelated to aquifer characteristics. Methods used to analyze the slug test results are described in Section 3.1. A summary list of the hydraulic properties determined from slug testing is provided in Table 4.1. A comparison of the average hydraulic conductivity, K, estimates obtained using the Bouwer and Rice and type-curve analysis methods is shown in Figure 4.1. As indicated, the method provided consistently lower values (generally within 35\%) than the corresponding type-curve-derived estimates. This general pattern for analytical method comparison is consistent with findings reported in Hyder and Butler (1995). A description of the performance and analysis of slug tests conducted at each well site is provided below.

\subsection{Well 299-W15-41}

A total of three slug withdrawal tests (two low and one high stress) were conducted on March 29, 2000. Both stress-level slug-test responses indicate an inelastic, high test formation permeability (i.e., test recovery within 30 seconds). A comparison of the normalized, low- and high-stress slug-test responses indicates a slightly delayed response for the high stress test. This slightly delayed response is attributed to early-time turbulent flow effects occurring during the high stress test. A comparison of K estimates indicates that slightly lower results ( $\sim 30 \%$ lower) were obtained for the Bouwer and Rice method. For the Bouwer and Rice method, estimates for K ranged between 12.1 and $16.3 \mathrm{~m} / \mathrm{d}$ (average $14.2 \mathrm{~m} / \mathrm{d}$ ), while the type-curve method provided estimates between 18.1 and $21.6 \mathrm{~m} / \mathrm{d}$ (average $19.9 \mathrm{~m} / \mathrm{d}$ ) for both stress-level tests. Selected examples of the slug-test analysis plots for this well are shown in Figure 4.2.

\subsection{Well 299-W22-45}

A total of four slug tests (two high and two low stress) were conducted on January 27 and 28, 2000. A comparison of the normalized, high- and low-stress, slug-test responses indicates a slight delay in test response behavior for the high-stress tests, which is attributable to early-time, turbulent flow effects. Identical behavior was evident for tests conducted at a particular stress level, suggesting that the well had been fully developed. All slug-test responses indicated a heterogeneous formation behavior, with a higher permeability zone located in proximity to the well screen (as indicated by the rapid recovery rate at early test times, which transitions to a slower recovery rate for the surrounding lower permeability material on the type-curve analysis plot in Figure 4.3). Heterogeneous formation test response can only be analyzed 
Table 4.1. Slug-Test Results

\begin{tabular}{|c|c|c|c|c|c|}
\hline \multirow[b]{2}{*}{ Test Well } & \multicolumn{2}{|c|}{ Test Parameters } & \multirow{2}{*}{$\begin{array}{c}\text { Bouwer and Rice } \\
\text { Analysis Method }\end{array}$} & \multicolumn{2}{|c|}{ Type-Curve Analysis Method } \\
\hline & $\begin{array}{c}\text { Aquifer } \\
\text { Thickness, } \\
\mathrm{b},{ }^{(\mathrm{a})} \mathrm{m} \\
\end{array}$ & $\begin{array}{c}\text { Test Interval } \\
\text { Saturated } \\
\text { Thickness, L, m } \\
\end{array}$ & & $\begin{array}{c}\text { Horizontal Hydraulic } \\
\text { Conductivity, } \mathrm{K}_{\mathrm{h},}{ }^{(\mathrm{b})} \mathrm{m} / \mathrm{d} \\
\end{array}$ & $\begin{array}{c}\text { Specific Storage, } \\
\mathrm{S}_{\mathrm{s}} \mathrm{m}^{-1} \\
\end{array}$ \\
\hline 299-W15-41 & 57.6 & 4.58 & $\begin{array}{c}12.1-16.3 \\
(14.2)\end{array}$ & $\begin{array}{c}18.1-21.6 \\
(19.9)\end{array}$ & $5.0 \mathrm{E}-06-1.0 \mathrm{E}-05$ \\
\hline 299-W22-45 & 77.0 & 5.67 & $\begin{array}{c}\text { Inner Zone: } 1.55 \text { - } 2.72 \\
(2.14) \\
\text { Outer Zone: }<0.4\end{array}$ & $\begin{array}{c}\text { Inner Zone: } 1.81-2.94 \\
(2.38) \\
\text { Outer Zone: } 0.09-0.18 \\
(0.14)\end{array}$ & $\begin{array}{l}2.1 \mathrm{E}-05-3.4 \mathrm{E}-05 \\
1.0 \mathrm{E}-06-2.1 \mathrm{E}-06\end{array}$ \\
\hline 299-W22-46 & 73.5 & 2.72 & $\begin{array}{c}2.16-2.69 \\
(2.43) \\
\end{array}$ & $\begin{array}{l}3.07-3.72 \\
(3.37)\end{array}$ & $5.5 \mathrm{E}-05-1.1 \mathrm{E}-04$ \\
\hline 299-W22-48 & 70.1 & 3.82 & $\begin{array}{c}1.21-1.62 \\
(1.42)\end{array}$ & $\begin{array}{c}1.56-2.16 \\
(1.86) \\
\end{array}$ & $1.5 \mathrm{E}-06-1.5 \mathrm{E}-05$ \\
\hline 299-W22-49 & 72.5 & 4.53 & $\begin{array}{c}5.79-6.29 \\
(6.04)\end{array}$ & $\begin{array}{c}7.73-8.21 \\
(7.97)\end{array}$ & $5.5 \mathrm{E}-06-1.5 \mathrm{E}-05$ \\
\hline 299-W22-50 & 73.5 & 4.30 & $\begin{array}{c}3.93-4.55 \\
(4.24) \\
\end{array}$ & $\begin{array}{c}5.44-5.96 \\
(5.70) \\
\end{array}$ & $6.3 \mathrm{E}-05-2.3 \mathrm{E}-05$ \\
\hline 299-W23-15 & 75.6 & 5.73 & $\begin{array}{c}\text { Inner Zone: } 1.24-1.87 \\
(1.55) \\
\text { Outer Zone: }<0.3\end{array}$ & $\begin{array}{c}\text { Inner Zone: } 1.24-1.90 \\
(1.58) \\
\text { Outer Zone: } 0.04-0.06 \\
(0.05)\end{array}$ & $\begin{array}{l}1.7 \mathrm{E}-04 \\
1.7 \mathrm{E}-05\end{array}$ \\
\hline 299-W26-13 & 76.2 & 10.7 & $\begin{array}{c}\text { Inner Zone: } 2.80 \\
\text { Outer Zone: }<0.42\end{array}$ & $\begin{array}{l}\text { Inner Zone: } 2.76 \\
\text { Outer Zone: } 0.09\end{array}$ & $\begin{array}{l}3.5 \mathrm{E}-05 \\
3.5 \mathrm{E}-05\end{array}$ \\
\hline 299-E33-334 & 4.81 & 5.64 & $\begin{array}{c}35.4-48.2 \\
\quad(41.8)\end{array}$ & $\begin{array}{c}38.9-50.1 \\
\quad(44.5)\end{array}$ & $2.0 \mathrm{E}-05$ \\
\hline 299-E33-335 & 4.80 & 4.65 & $\begin{array}{c}42.5-56.0 \\
(49.3) \\
\end{array}$ & $\begin{array}{c}45.4-58.8 \\
(52.1) \\
\end{array}$ & $2.0 \mathrm{E}-05$ \\
\hline $699-43-44$ & 5.21 & 4.90 & $\begin{array}{c}1.29-2.18 \\
(1.74)\end{array}$ & $\begin{array}{c}1.51-2.38 \\
(1.95)\end{array}$ & $3.0 \mathrm{E}-06$ \\
\hline $\begin{array}{l}\text { Note: For all } \\
\text { Number in pa } \\
\text { (a) Determi } \\
\text { (b) Assume }\end{array}$ & $\begin{array}{l}\text { wells, } r_{c}= \\
\text { heses is av } \\
\text { in most ca } \\
\text { be uniforn }\end{array}$ & $\begin{array}{l}051 \mathrm{~m} ; \mathrm{r}_{\mathrm{w}}=0.11 \\
\mathrm{e} \text {. } \\
\text { from projection } \\
\text { hin the well-scre }\end{array}$ & $\begin{array}{l}\text { (see Nomenclature for } \\
\text { m neighboring wells. } \\
\text { test section. }\end{array}$ & & \\
\hline
\end{tabular}

quantitatively using the type-curve analysis method. For the type-curve method, estimates for $\mathrm{K}$ for the higher permeability inner zone ranged between 1.81 and $2.94 \mathrm{~m} / \mathrm{d}$ (average $2.38 \mathrm{~m} / \mathrm{d}$ ), while estimates for the outer lower permeability zone ranged between 0.09 and $0.18 \mathrm{~m} / \mathrm{d}$ (average $0.14 \mathrm{~m} / \mathrm{d}$ ) for both stresslevel tests. Analysis estimates of the radial distance of the higher permeability formation ranged between 1.7 and 1.9 m surrounding the well. Results obtained from the Bouwer and Rice method are less definitive for tests exhibiting heterogeneous formation response behavior. Bouwer and Rice method estimates for inner high permeability formation ranged between 1.55 and $2.72 \mathrm{~m} / \mathrm{d}$ (average $2.14 \mathrm{~m} / \mathrm{d}$ ), while estimates for the outer lower permeability zone were $<0.4 \mathrm{~m} / \mathrm{d}$ for both stress-level tests. No estimate of radial distance of the inner high permeability zone is possible with the Bouwer and Rice method. Selected examples of the analysis plots for this well are shown in Figure 4.3. 


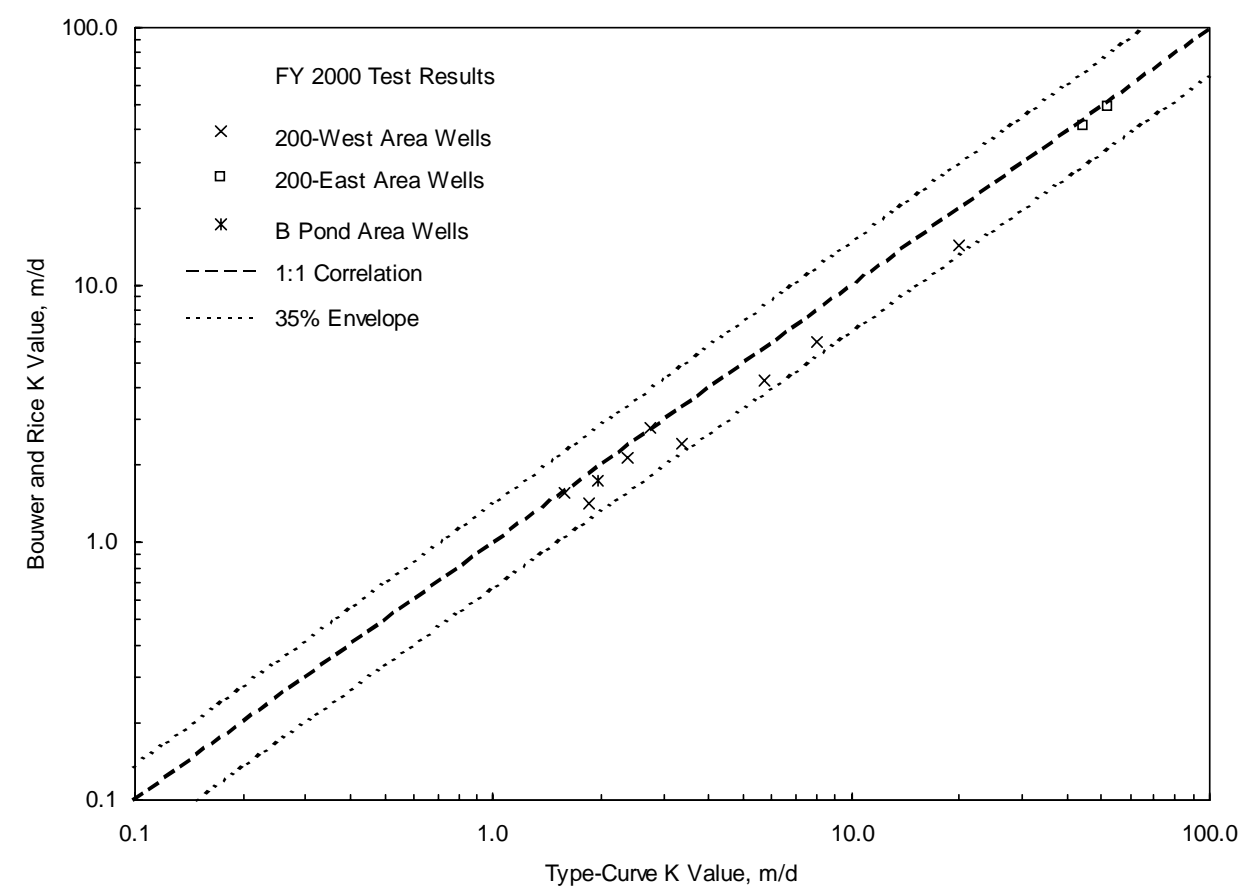

Figure 4.1. Comparison of Hydraulic Conductivity Estimates Obtained Using Bouwer and Rice and Type-Curve Analysis Methods

\subsection{Well 299-W22-46}

A total of four slug tests (two high and two low stress) were conducted on April 13, 2000. Selected examples of the analysis plots for this well are shown in Figure 4.4. A comparison of the normalized, high- and low-stress, slug-test responses indicates only a slight delay in test response behavior for the high-stress tests, which is attributable to early-time, turbulent flow effects. Identical behavior was evident for tests conducted at a particular stress level, suggesting that the well had been fully developed. An examination of individual responses also indicates a relatively homogeneous, inelastic (linear) response displayed on the Bouwer and Rice analysis plot in Figure 4.4. A comparison of $\mathrm{K}$ estimates indicates that slightly lower results ( $\sim 30 \%$ lower) were obtained for the Bouwer and Rice method. For the Bouwer and Rice method, estimates for K ranged between 2.16 and $2.69 \mathrm{~m} / \mathrm{d}$ (average $2.43 \mathrm{~m} / \mathrm{d}$ ), while the type-curve method provided estimates between 3.07 and $3.72 \mathrm{~m} / \mathrm{d}$ (average $3.37 \mathrm{~m} / \mathrm{d}$ ) for both stress-level tests.

\subsection{Well 299-W22-48}

A total of four slug tests (two high and two low stress) were conducted on January 26, 2000. Selected examples of the analysis plots for this well are shown in Figure 4.5. A comparison of the normalized, high- and low-stress, slug-test responses indicates a slight delay in test response behavior for the highstress tests, which is attributed to excessive well screen dewatering (i.e., Ho $>25 \%$ of the saturated well screen length). For this reason, the low-stress test results are believed to provide more representative 

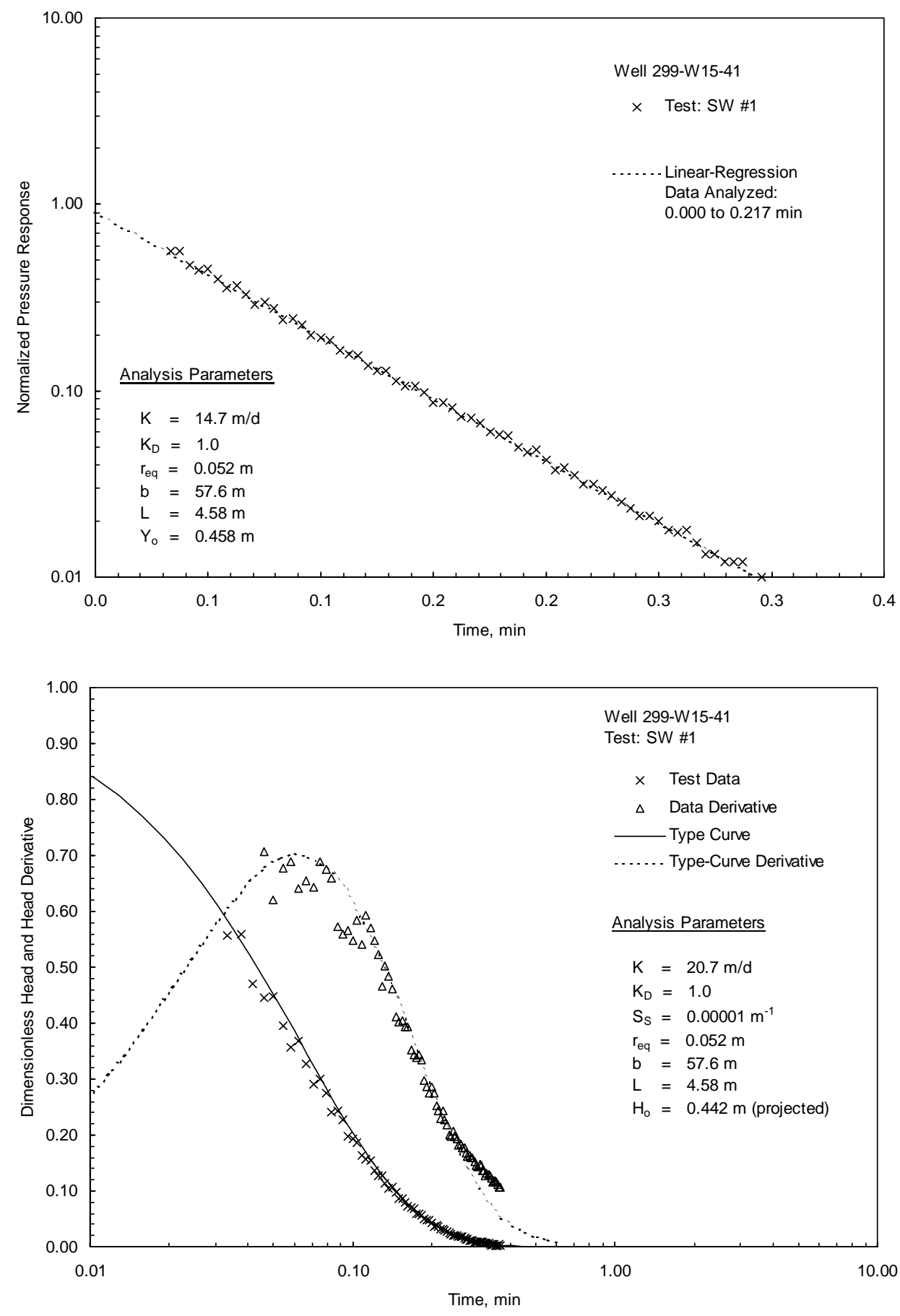

Figure 4.2. Selected Slug-Test Analysis Plots for Well 299-W15-41 (Bouwer and Rice method [top] and type-curve method [bottom]) 

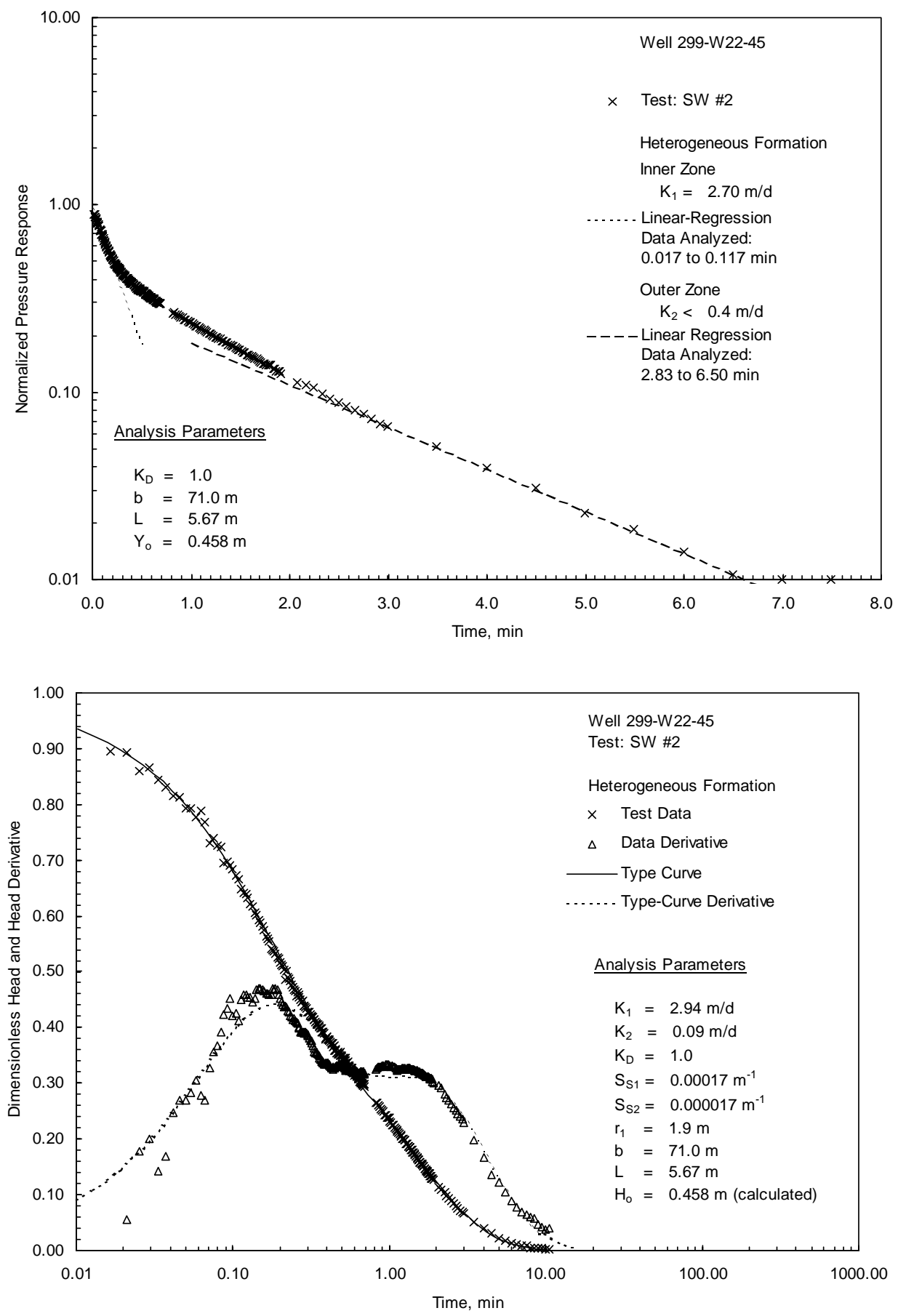

Figure 4.3. Selected Slug-Test Analysis Plots for Well 299-W22-45 (Bouwer and Rice method [top] and type-curve method [bottom]) 

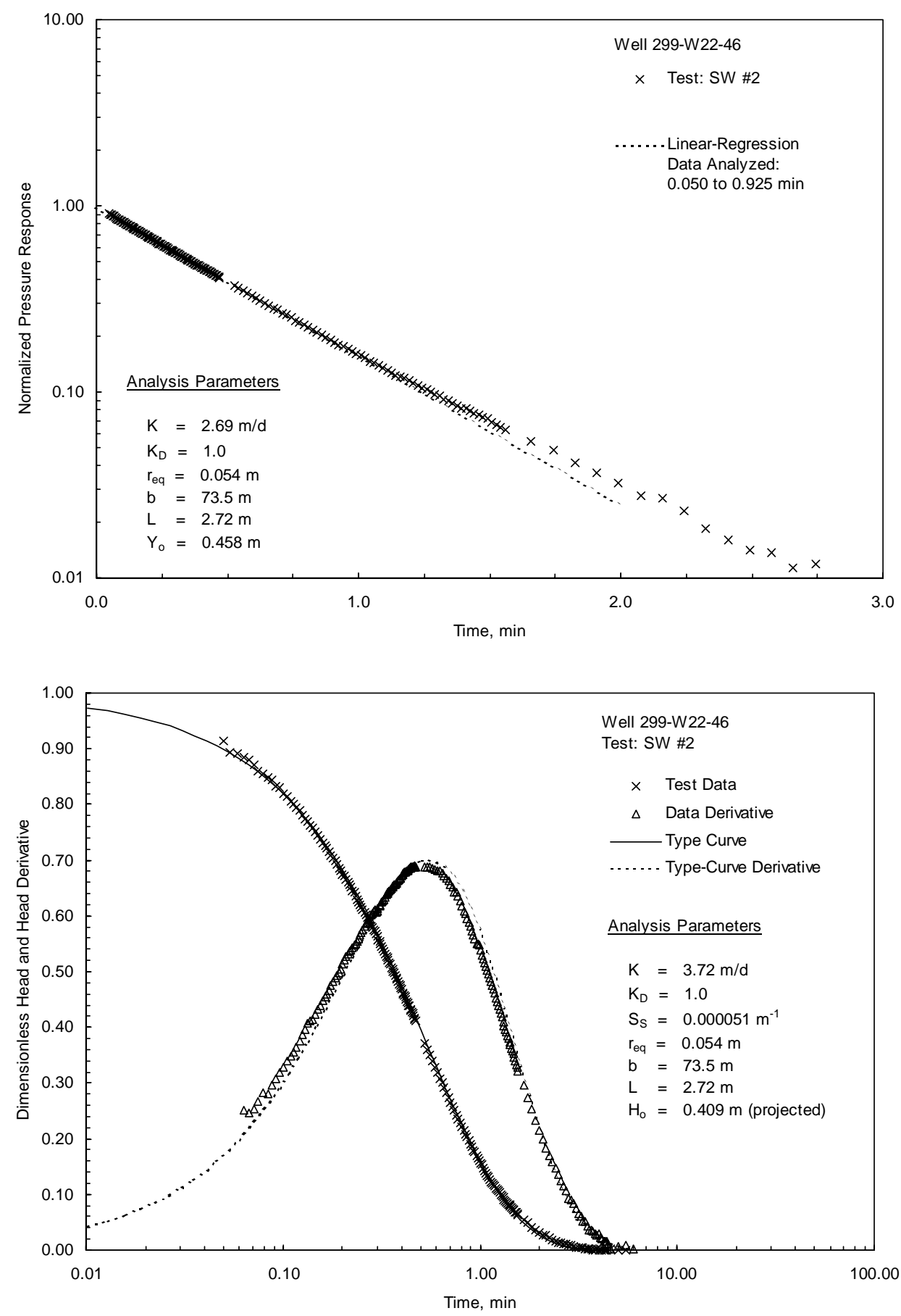

Figure 4.4. Selected Slug-Test Analysis Plots for Well 299-W22-46 (Bouwer and Rice method [top] and Type-Curve Method [Bottom]) 

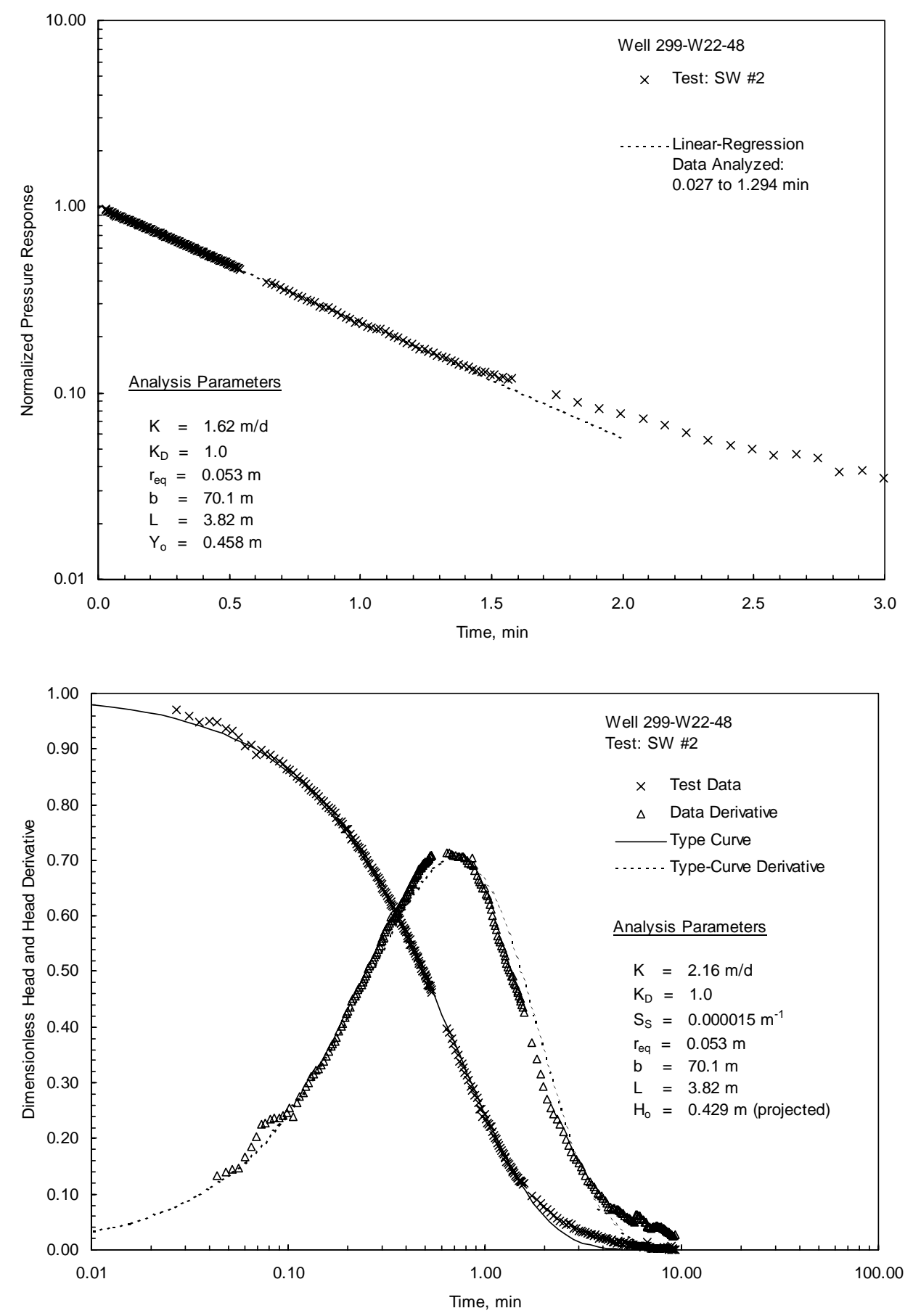

Figure 4.5. Selected Slug-Test Analysis Plots for Well 299-W22-48 (Bouwer and Rice method [top] and type-curve method [bottom]) 
estimates. Identical behavior was evident for tests conducted at a particular stress level, suggesting that the well had been fully developed. An examination of individual responses also indicates a relatively homogeneous, inelastic (linear) response displayed on the Bouwer and Rice analysis plot in Figure 4.5. A comparison of $\mathrm{K}$ estimates indicates that slightly lower results $(\sim 30 \%$ lower) were obtained for the Bouwer and Rice method. For the Bouwer and Rice method, estimates for K ranged between 1.21 and $1.62 \mathrm{~m} / \mathrm{d}$ (average $1.42 \mathrm{~m} / \mathrm{d}$ ), while the type-curve method provided estimates between 1.56 and $2.16 \mathrm{~m} / \mathrm{d}$ (average $1.86 \mathrm{~m} / \mathrm{d}$ ) for both stress-level tests.

\subsection{Well 299-W22-49}

A total of four slug tests (two high and two low stress) were conducted on January 27, 2000. Selected examples of the analysis plots for this well are shown in Figure 4.6. A comparison of the normalized, high- and low-stress, slug-test responses indicates a slight delay in test response behavior for the highstress tests, which is attributable to excessive well screen dewatering (i.e., Ho $\sim 25 \%$ of the saturated well screen length). For this reason, the low-stress test results are believed to provide more representative estimates. Identical behavior was evident for tests conducted at a particular stress level, suggesting that the well had been fully developed. An examination of individual responses also indicates a relatively homogeneous, inelastic (linear) response displayed on the Bouwer and Rice analysis plot in Figure 4.6. A comparison of $\mathrm{K}$ estimates indicates that slightly lower results ( $25 \%$ lower) were obtained for the Bouwer and Rice method. For the Bouwer and Rice method, estimates for K ranged between 5.79 and $6.29 \mathrm{~m} / \mathrm{d}$ (average $6.04 \mathrm{~m} / \mathrm{d}$ ), while the type-curve method provided estimates between 7.73 and $8.21 \mathrm{~m} / \mathrm{d}$ (average $7.97 \mathrm{~m} / \mathrm{d}$ ) for both stress-level tests.

\subsection{Well 299-W22-50}

A total of four slug tests (two high and two low stress) were conducted on April 10, 2000. Selected examples of the analysis plots for this well are shown in Figure 4.7. A comparison of the normalized, high- and low-stress, slug-test responses indicates a slight delay in test response behavior for the highstress tests, which is attributable to excessive well screen dewatering (i.e., Ho $\sim 25 \%$ of the saturated well screen length). For this reason, the low-stress test results are believed to provide more representative estimates. Identical behavior was evident for tests conducted at a particular stress level, suggesting that the well had been fully developed. An examination of individual responses also indicates a relatively homogeneous, inelastic (linear) response displayed on the Bouwer and Rice analysis plot in Figure 4.7. A comparison of $\mathrm{K}$ estimates indicates that slightly lower results ( $\sim 25 \%$ lower $)$ were obtained for the Bouwer and Rice method. For the Bouwer and Rice method, estimates for K ranged between 3.93 and $4.55 \mathrm{~m} / \mathrm{d}$ (average $4.24 \mathrm{~m} / \mathrm{d}$ ), while the type-curve method provided estimates between 5.44 and $5.96 \mathrm{~m} / \mathrm{d}$ (average $5.70 \mathrm{~m} / \mathrm{d}$ ) for both stress-level tests.

\subsection{Well 299-W23-15}

A total of four slug tests (two high and two low stress) were conducted on January 24, 2000. A comparison of the normalized, high- and low-stress, slug-test responses indicates a slight delay in test response behavior for the high-stress tests, which is attributable to excessive well screen dewatering (i.e., 

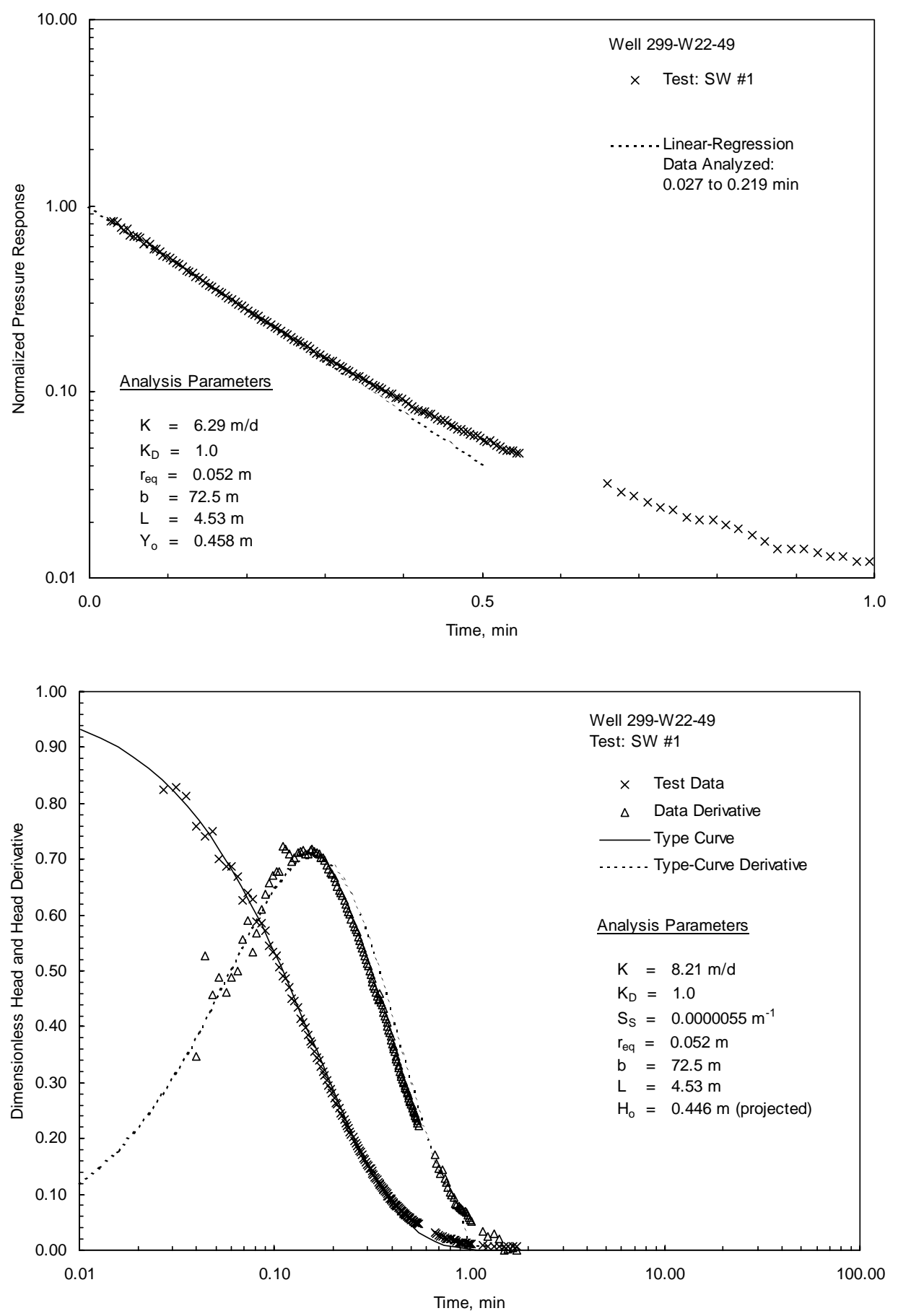

Figure 4.6. Selected Slug-Test Analysis Plots for Well 299-W22-49 (Bouwer and Rice method [top] and type-curve method [bottom]) 

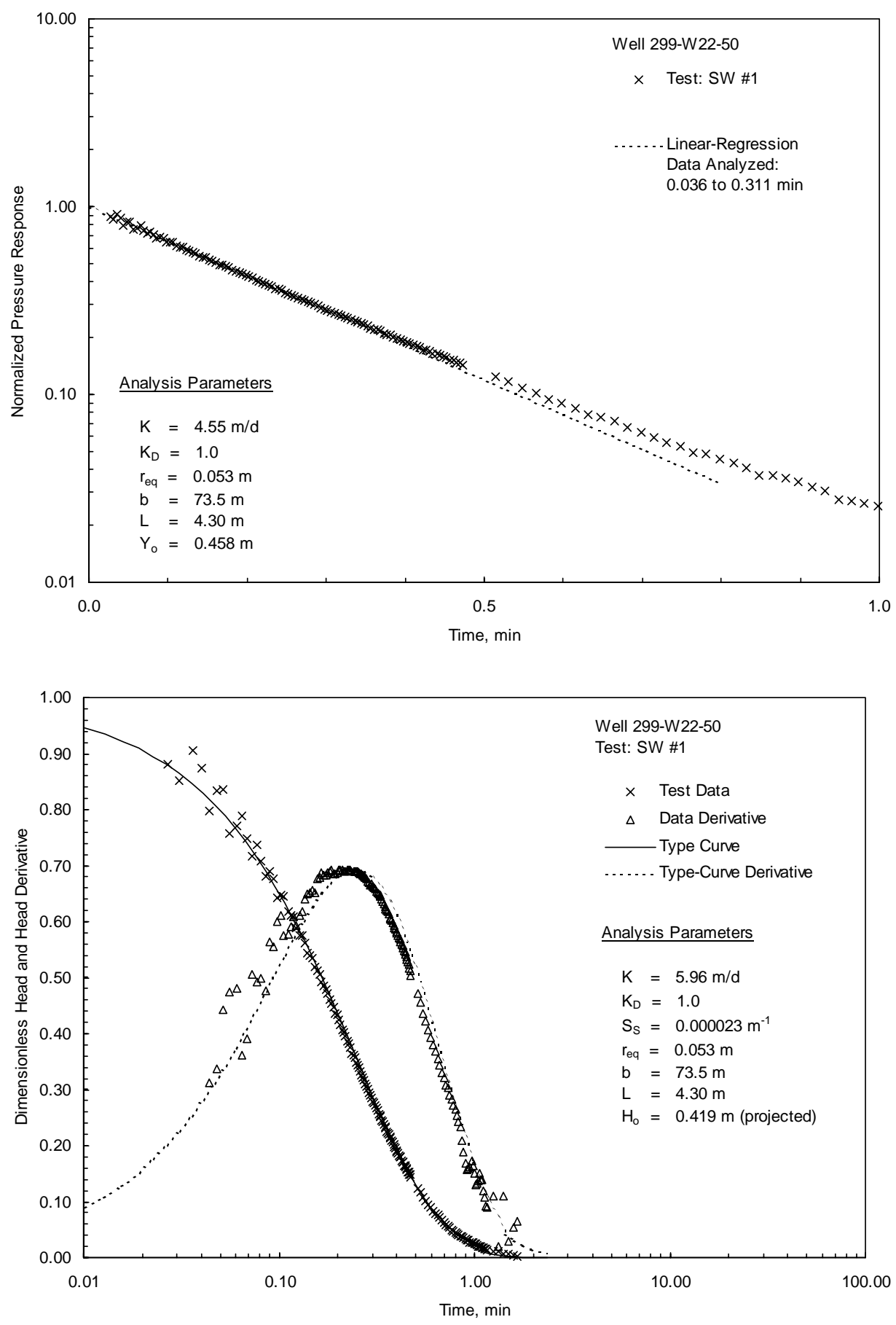

Figure 4.7. Selected Slug-Test Analysis Plots for Well 299-W22-50 (Bouwer and Rice method [top] and type-curve method [bottom]) 
Ho $\sim 20 \%$ of the saturated well screen length). For this reason, the low-stress test results are believed to provide more representative estimates. Identical behavior was evident for tests conducted at a particular stress level, suggesting that the well had been fully developed. All slug-test responses indicated a heterogeneous formation behavior, with a higher permeability zone located in proximity to the well screen (as indicated by the rapid recovery rate at early test times, which transitions to a slower recovery rate for the surrounding lower permeability material on the type-curve analysis plot in Figure 4.8). Heterogeneous formation test response can only be analyzed quantitatively using the type-curve analysis method. For the type-curve method, estimates for $\mathrm{K}$ for the higher permeability inner zone ranged between 1.24 and $1.90 \mathrm{~m} / \mathrm{d}$ (average $1.58 \mathrm{~m} / \mathrm{d}$ ), while estimates for the outer lower permeability zone ranged between 0.04 and $0.06 \mathrm{~m} / \mathrm{d}$ (average $0.05 \mathrm{~m} / \mathrm{d}$ ) for both stress-level tests. An estimate of the radial distance of the higher permeability formation of $1.8 \mathrm{~m}$ surrounding the well was obtained for both stresslevel tests. Results obtained from the Bouwer and Rice method are less definitive for tests exhibiting heterogeneous formation response behavior. Bouwer and Rice method estimates for inner high permeability formation ranged between 1.24 and $1.87 \mathrm{~m} / \mathrm{d}$ (average $1.55 \mathrm{~m} / \mathrm{d}$ ), while estimates for the outer lower permeability zone were $<0.3 \mathrm{~m} / \mathrm{d}$ for both stress-level tests. No estimate of radial distance of the inner high permeability zone is possible with the Bouwer and Rice method. Selected examples of the analysis plots for this well are shown in Figure 4.8.

\subsection{Well 299-W26-13}

A total of four slug tests (two high and two low stress) were conducted on January 25, 2000. A comparison of the normalized, high- and low-stress, slug-test responses indicates nearly identical test response behavior suggesting that the well had been fully developed. All slug-test responses indicated a heterogeneous formation behavior, with a higher permeability zone located in proximity to the well screen (as indicated by the rapid recovery rate at early test times, which transitions to a slower recovery rate for the surrounding lower permeability material on the type-curve analysis plot in Figure 4.9). Heterogeneous formation test response can only be analyzed quantitatively using the type-curve analysis method. For the type-curve method, an estimate of $2.76 \mathrm{~m} / \mathrm{d}$ for $\mathrm{K}$ was obtained for the higher permeability inner zone, while an estimate for the outer lower permeability zone of $0.09 \mathrm{~m} / \mathrm{d}$ was calculated for both stress-level tests. Analysis estimates of the radial distance of the higher permeability formation ranged between 4.0 and $4.1 \mathrm{~m}$ surrounding the well. Results obtained from the Bouwer and Rice method are less definitive for tests exhibiting heterogeneous formation response behavior. Bouwer and Rice method estimate for inner high permeability formation equaled $2.80 \mathrm{~m} / \mathrm{d}$, while the estimate for the outer lower permeability zone was $<0.42 \mathrm{~m} / \mathrm{d}$ for both stress-level tests. No estimate of radial distance of the inner high permeability zone is possible with the Bouwer and Rice method. Selected examples of the analysis plots for this well are shown in Figure 4.9. 

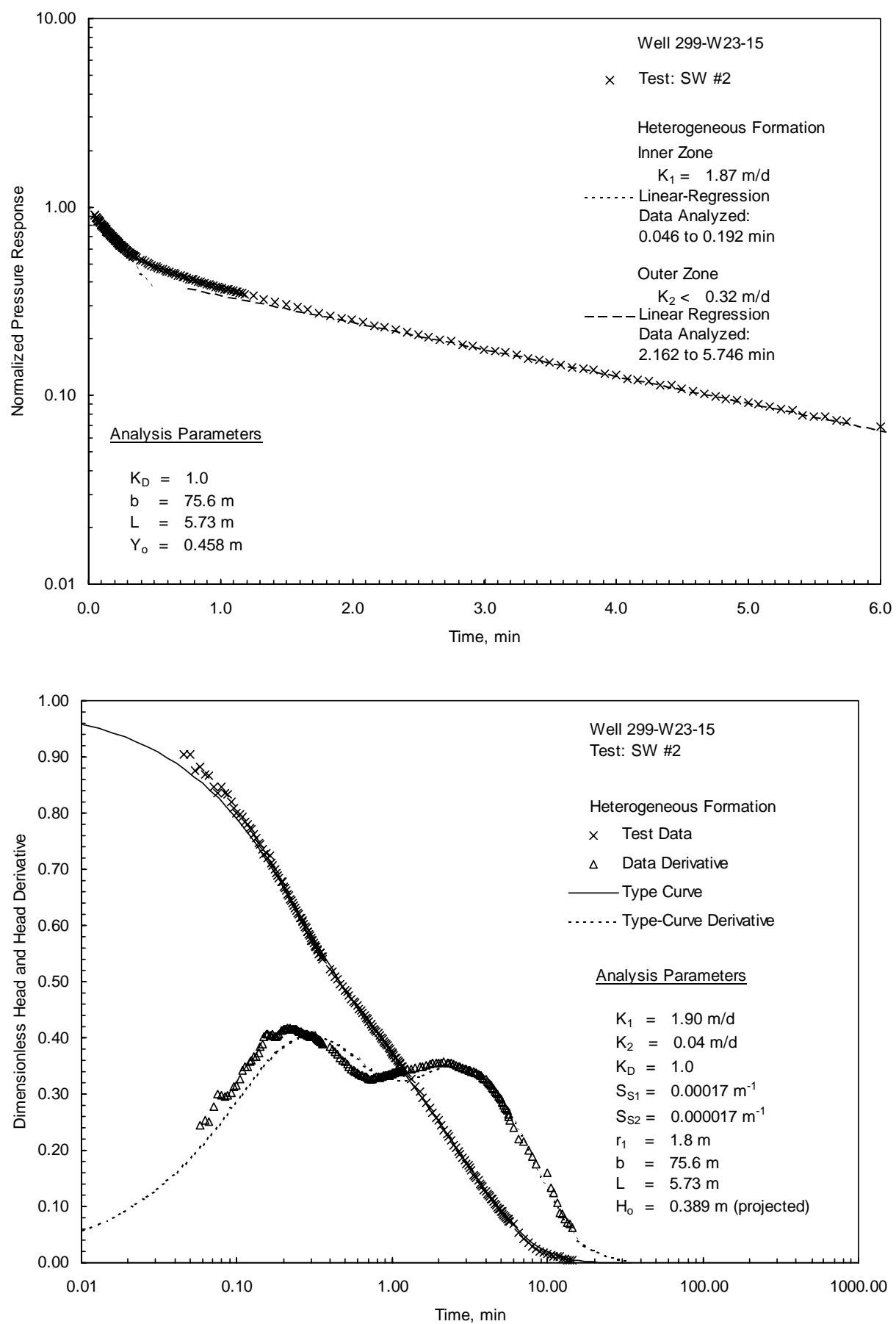

Figure 4.8. Selected Slug-Test Analysis Plots for Well 299-W23-15 (Bouwer and Rice method [top] and type-curve method [bottom]) 

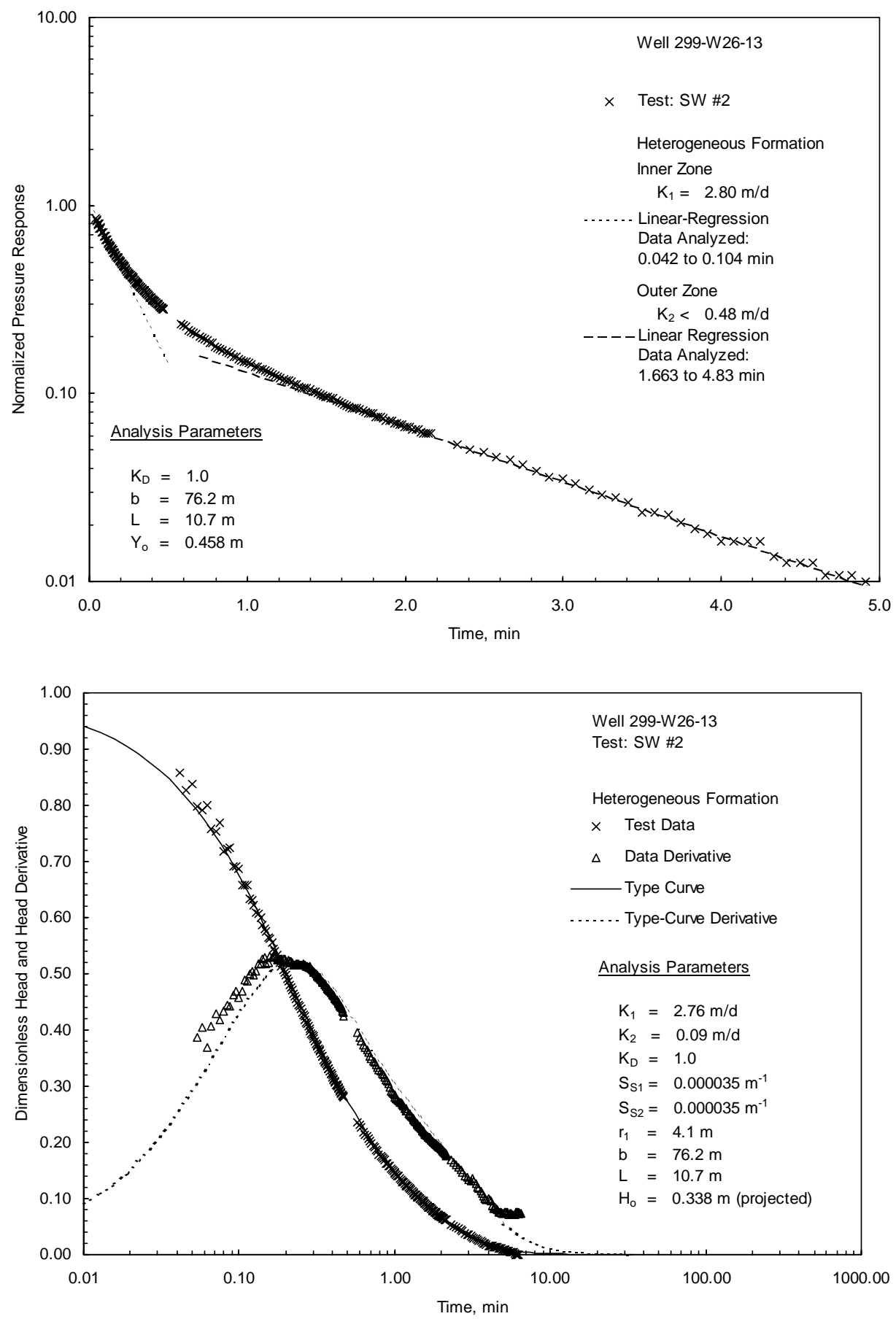

Figure 4.9. Selected Slug-Test Analysis Plots for Well 299-W26-13 (Bouwer and Rice method [top] and type-curve method [bottom]) 


\subsection{Well 299-E33-334}

A total of six slug tests (three high and three low stress) were conducted on February 1, 2000. Both stress-level slug-test responses indicate a high permeability for the test formation (i.e., test recovery within 10 seconds). Because of the high formation permeability, the slug tests were largely ineffectual in producing significant test response for analysis. A comparison of $\mathrm{K}$ estimates indicates that slightly lower results ( $\sim 5 \%$ lower) were obtained for the Bouwer and Rice method. For the Bouwer and Rice method, estimates for K ranged between 35.4 and $48.2 \mathrm{~m} / \mathrm{d}$ (average $41.8 \mathrm{~m} / \mathrm{d}$ ), while the type-curve method provided estimates between 38.9 and $50.1 \mathrm{~m} / \mathrm{d}$ (average $44.5 \mathrm{~m} / \mathrm{d}$ ) for both stress-level tests. Selected examples of the slug-test analysis plots for this well are shown in Figure 4.10. (Note: as for most slug tests, data for the first 2 to 3 seconds of the test are not reliable due to the effects of slugging rod removal and, therefore, are not shown in the analysis figure).

\subsection{Well 299-E33-335}

A total of six slug tests (three high and three low stress) were conducted on March 28, 2000. Both stress-level slug-test responses indicate a high permeability for the test formation (i.e., test recovery within 10 seconds). Because of the high formation permeability, the slug tests (particularly the low-stress tests) were largely ineffectual in producing a significant test response for analysis. A comparison of $\mathrm{K}$ estimates indicates that slightly lower results $(\sim 5 \%$ lower) were obtained for the Bouwer and Rice method. For the Bouwer and Rice method, estimates for K ranged between 42.5 and $56.0 \mathrm{~m} / \mathrm{d}$ (average $49.3 \mathrm{~m} / \mathrm{d}$ ), while the type-curve method provided estimates between 45.4 and $58.8 \mathrm{~m} / \mathrm{d}$ (average $52.1 \mathrm{~m} / \mathrm{d}$ ) for both stress-level tests. Selected examples of the slug-test analysis plots for this well are shown in Figure 4.11. (Note: as for most slug tests, data for the first 2 to 3 seconds of the test are not reliable due to the effects of slugging rod removal and, therefore, are not shown in the analysis figure).

\subsection{Well 699-43-44}

A total of four slug tests (two high and two low stress) were conducted on January 28, 2000. Selected examples of the analysis plots for this well are shown in Figure 4.12. A comparison of the normalized, high- and low-stress, slug-test responses indicates a slight delay in test response behavior for the highstress tests, which is attributable to excessive well screen dewatering (i.e., Ho $25 \%$ of the saturated well screen length). For this reason, the low-stress test results are believed to provide more representative estimates. Identical behavior was evident for tests conducted at a particular stress level, suggesting that the well had been fully developed. An examination of individual responses also indicates a relatively homogeneous, inelastic (linear) response displayed on the Bouwer and Rice analysis plot in Figure 4.12. A comparison of $\mathrm{K}$ estimates indicates that slightly lower results ( $10 \%$ lower) were obtained for the Bouwer and Rice method. For the Bouwer and Rice method, estimates for K ranged between 1.29 and $2.18 \mathrm{~m} / \mathrm{d}$ (average $1.74 \mathrm{~m} / \mathrm{d}$ ), while the type-curve method provided estimates between 1.51 and $2.38 \mathrm{~m} / \mathrm{d}$ (average $1.95 \mathrm{~m} / \mathrm{d}$ ) for both stress-level tests. 

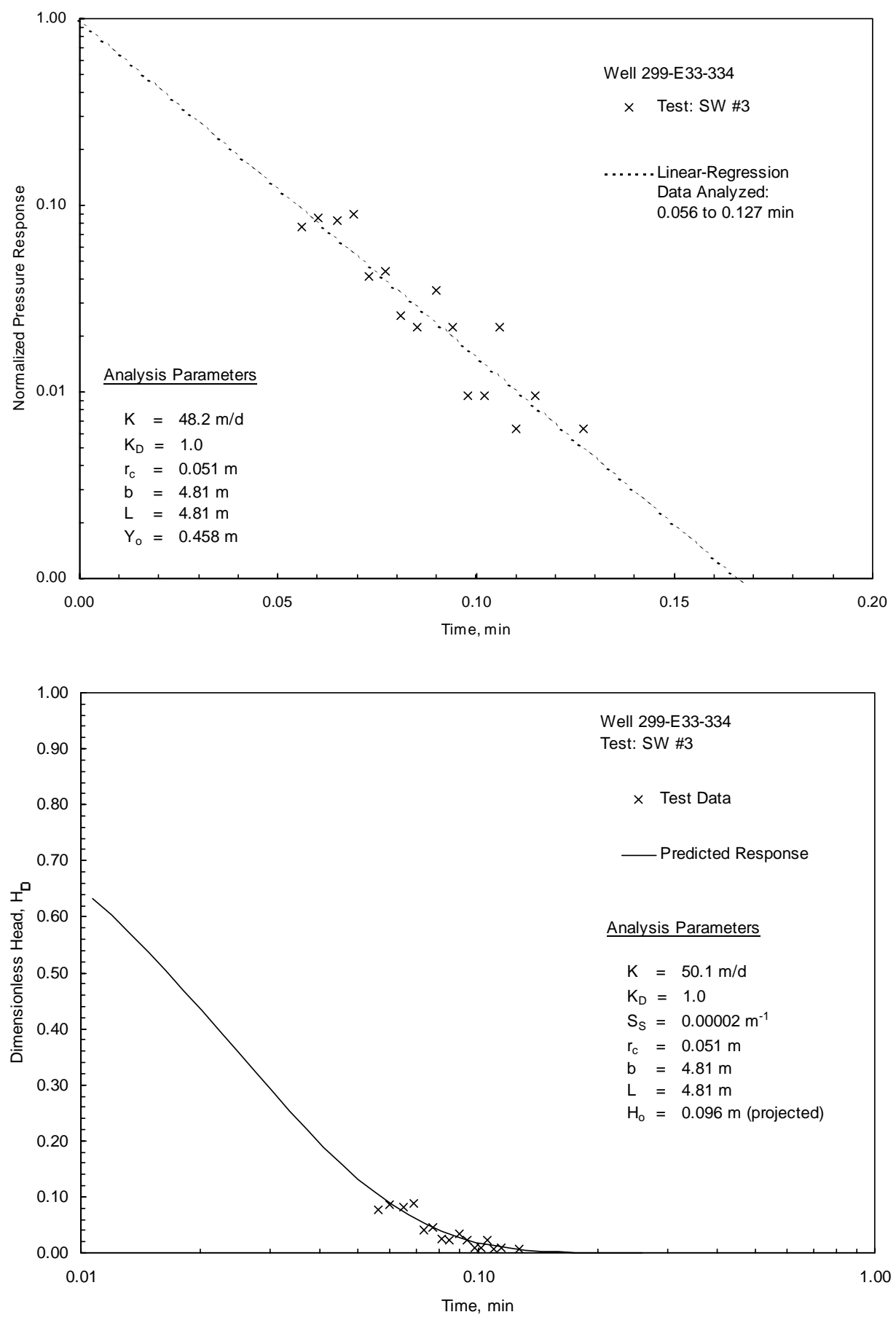

Figure 4.10. Selected Slug-Test Analysis Plots for Well 299-E33-334 (Bouwer and Rice method [top] and type-curve method [bottom]) 

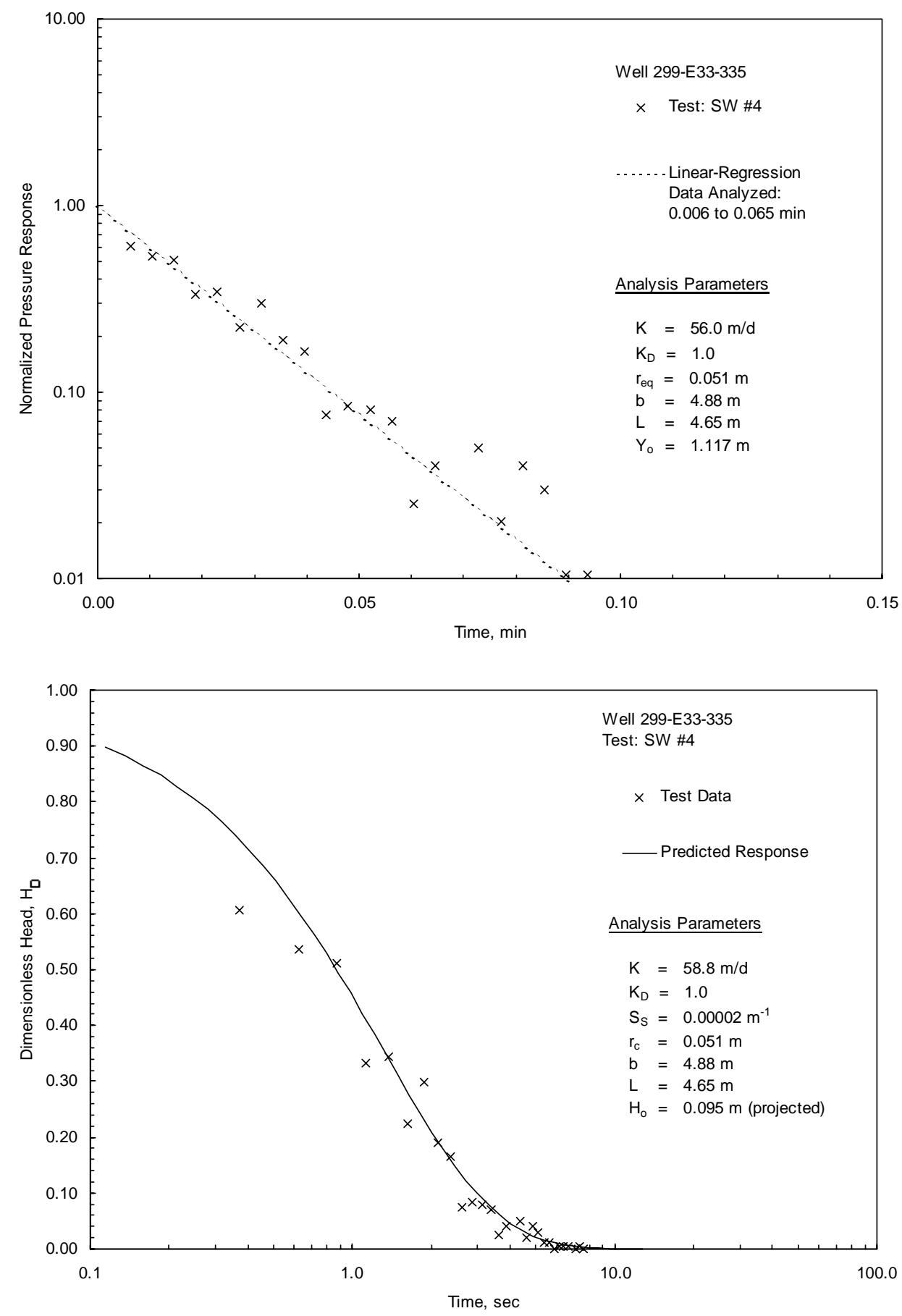

Figure 4.11. Selected Slug-Test Analysis Plots for Well 299-E33-335 (Bouwer and Rice method [top] and type-curve method [bottom]) 

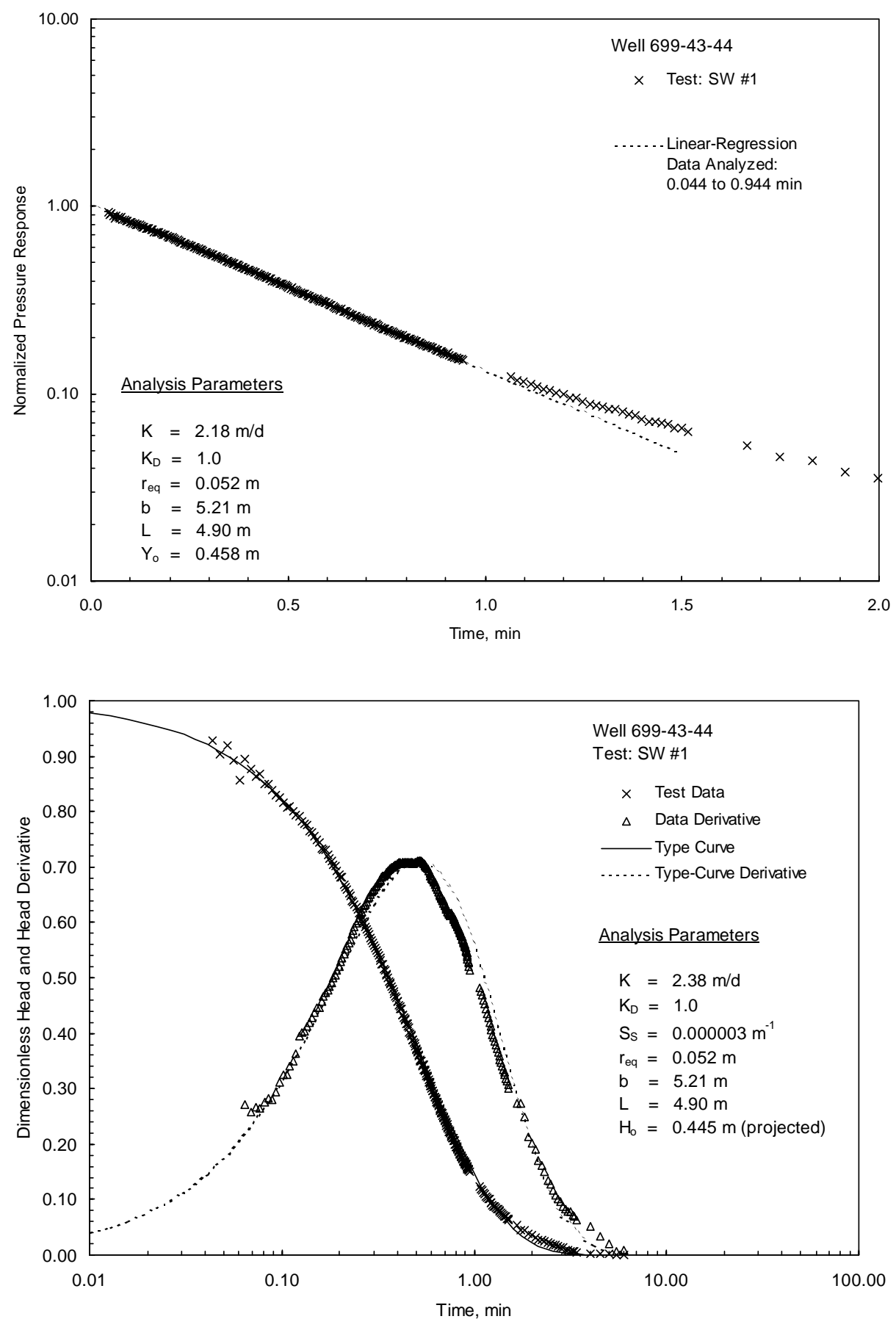

Figure 4.12. Selected Slug-Test Analysis Plots for Well 699-43-44 (Bouwer and Rice method [top] and type-curve method [bottom]) 


\subsection{Tracer-Dilution Test Results}

Results from the tracer-dilution phase of the single-well tracer testing were analyzed using the methods described in Section 3.2.1. As noted previously, to be strictly valid, the analytical assumptions require that the dilution occurs only as the result of lateral groundwater inflow (i.e., no vertical groundwater flow). As will be discussed, tracer-dilution tests conducted at wells 299-W22-49 and 699-43-44 exhibited evidence of upward vertical flow conditions within the well-screen section. The vertical in-well flow conditions subsequently were corroborated by vertical flow tracer tests and/or EM flow meter surveys conducted in the wells. For both wells a calculation of the average $v_{w}$ was attempted. However, the results for these wells are highly suspect and should only be used for qualitative comparison purposes. A description of the performance and analysis of the tracer-dilution tests conducted in five of the test wells is provided in the following sections.

\subsection{Well 299-W15-41}

A single-well tracer-dilution test began May 8, 2000 (1306 Pacific daylight time) by introducing $2.44 \mathrm{~L}$ of tracer solution (containing $7.80 \mathrm{~g}$ of bromide) within the $5.05-\mathrm{m}$ well-screen section (66.04 to $71.09 \mathrm{~m}$ below top of casing). The tracer was introduced into the well using a $25-\mathrm{mm}$ diameter polypropylene tube that was open at a depth setting of $70.6 \mathrm{~m}$ below top of casing. Following tracer introduction, an equilibration time of $\sim 20$ minutes was observed to allow for dissipation of the displaced water from the tube into the surrounding well-screen column. After the equilibration period, the tube was slowly raised out of the well-water column, causing emplacement of the $2.44 \mathrm{~L}$ of prepared tracer. The tube was then slowly lowered and raised two times within the water column over a 5-minute period to mix the tracer within the well-screen section. The designed concentration within the well screen following mixing of the added tracer was $\sim 200 \mathrm{mg} / \mathrm{L}$. In FY 1999, the tracer was mixed using a bottom, in-line static mixer. Results from the FY 1999 field investigations, however, suggested that use of the bottom-line mixer may have caused too much stress during the mixing process, causing influx of nontracered water into the well during the mixing process. For this reason, the bottom-line mixer was not used during the FY 2000 field investigation program.

Following mixing of the tracer solution, an assembly of five bromide probe sensors, spaced uniformly at a separation distance of $0.9 \mathrm{~m}$, was slowly lowered into the well. Final depth settings for the five sensors were $67.0,67.9,68.8,69.7$, and $70.6 \mathrm{~m}$ below top of casing. Installation of the assembly was completed in $\sim 25$ minutes, following the mixing of the tracer within the well-screen section. The concentration within the borehole following emplacement and equilibration of the sensors (i.e., after 39 minutes following initial mixing) was $\sim 130 \mathrm{mg} / \mathrm{L}$, ranging between 111 and $136 \mathrm{mg} / \mathrm{L}$ for the various sensor-depth settings. The average initial concentration within the well screen, $\mathrm{C}_{\mathrm{o}}$, based on backprojection of the fitted linear-regression concentration response to time $=0$ minute, was $152 \mathrm{mg} / \mathrm{L}$ (shown in Figure 5.1). The dilution and dissipation within the well screen were observed for a period of 2,714 minutes (1.88 days). At the end of the test, the average concentration was $1.3 \mathrm{mg} / \mathrm{L}$. 


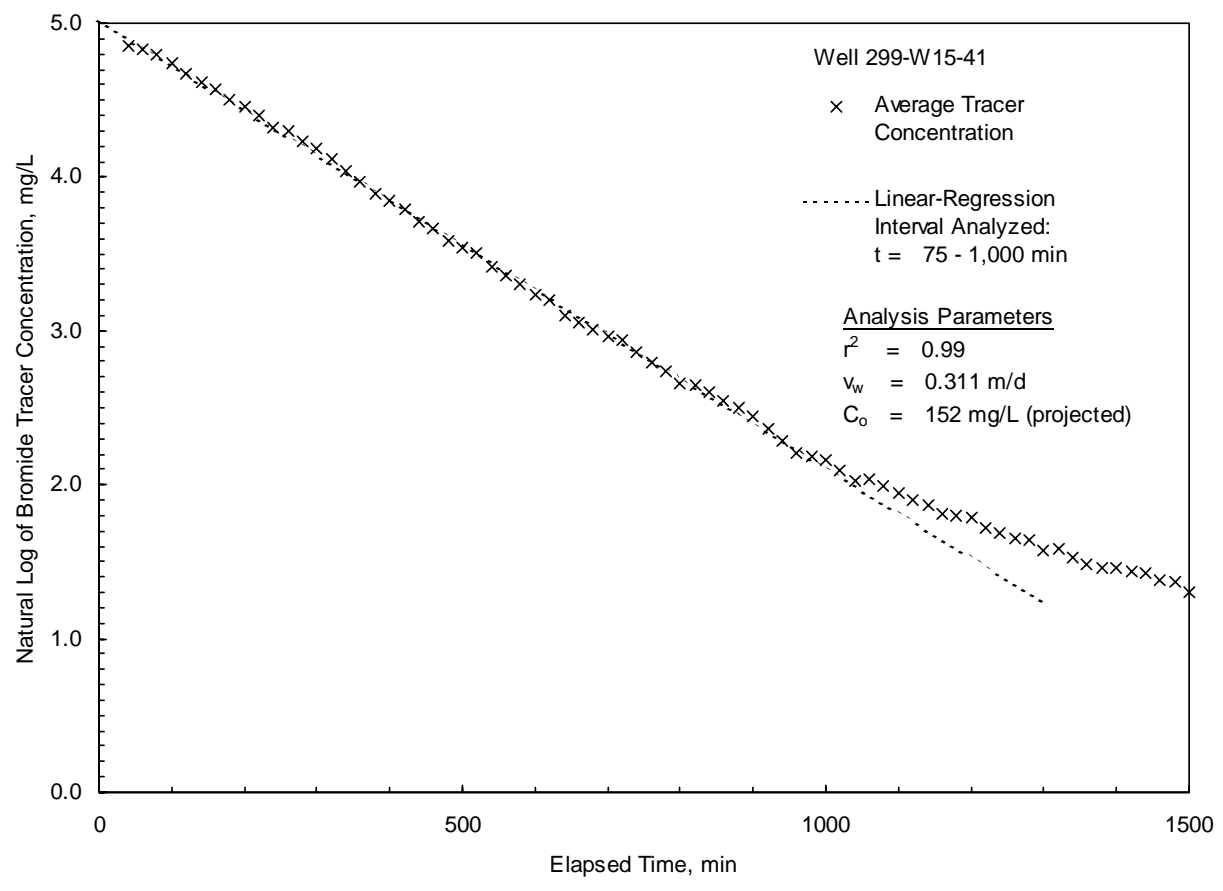

Figure 5.1. Average Tracer-Dilution Test Results Within Well 299-W15-41

Visual examination of the dilution patterns for the various sensor-depth settings indicates no significant vertical flow conditions within the well-screen section. The natural log of concentration versus time depth-setting plots exhibits linear relationships over most of the period of observation for the individual sensor locations. At low bromide concentrations (i.e., $<8 \mathrm{mg} / \mathrm{L}$ ), however, non-linear responses were exhibited for the lowest three probe depth-settings $(68.8,69.7$, and $70.6 \mathrm{~m})$. The reason for the nonlinear dilution response at these probes sites at lower tracer concentrations is not known.

The observed dilution pattern versus time can be analyzed to calculate $\mathrm{v}_{\mathrm{w}}$, using Equation (3.3). Linear-regression analysis of the average dilution response (shown in Figure 5.1) for the five sensor-depth settings within the well screen $\left(r^{2}=0.99\right)$ indicates a slope on the natural log of concentration versus time of $-0.002916 \mathrm{~min}^{-1}$. The calculated average $\mathrm{A} / \mathrm{V}$ relationship for the test interval, taking into account the presence of sensor instrumentation/cable test system cross-sectional area, is $13.505 \mathrm{~m}^{-1}$. Based on these observed and measured parameters, an average calculated $\mathrm{v}_{\mathrm{w}}$ is $0.311 \mathrm{~m} / \mathrm{d}$.

If lateral groundwater-flow conditions occur throughout the entire well, then a comparison of the calculated well velocities at the various sensor-depth settings can provide an assessment of the vertical permeability profile within the well-screen section. A comparison of the average well-flow velocities at the five individual sensor-depth settings indicates the highest in-well flow velocities for the middle and lower sensor-depth settings. If it can be assumed that a direct correlation between well-flow velocity and aquifer permeability exists for the well/aquifer site, then higher permeabilities occur within the lower half of the well-screen section, with the highest permeability occurring for the third depth setting $(68.8 \mathrm{~m}$ below top of casing). Table 5.1 summarizes results from the tracer-dilution test at well 299-W15-41. 
Table 5.1. Tracer-Dilution Test Results for Well 299-W15-41

\begin{tabular}{||c|c|c|c|c|c||}
\hline $\begin{array}{c}\text { Well Sensor/ } \\
\text { Depth Setting, } \\
\text { m, below top of } \\
\text { casing }\end{array}$ & $\begin{array}{c}\text { Tracer } \\
\text { Concentration/ } \\
\text { Dilution Slope, } \\
\mathrm{d}(\ln \text { C) dt min }\end{array}$ & $\begin{array}{c}\text { Linear- } \\
\text { Regression } \\
\text { Correlation } \\
\text { Coefficient, } \\
\mathrm{r}^{2}\end{array}$ & $\begin{array}{c}\text { Projected Initial } \\
\text { Tracer } \\
\text { Concentration, } \\
\mathrm{C}_{\mathrm{o}}, \mathrm{mg} / \mathrm{L}\end{array}$ & $\begin{array}{c}\text { Well } \\
\text { Measurement } \\
\text { Area/Volume } \\
\text { Ratio, } \\
\mathrm{A} / \mathrm{V}, \mathrm{m}^{-1}\end{array}$ & $\begin{array}{c}\text { Calculated } \\
\text { Well-Screen } \\
\text { Flow Velocity, } \\
\mathrm{v}_{\mathrm{w}}, \mathrm{m} / \mathrm{d}\end{array}$ \\
\hline \hline 67.0 & -0.002195 & 0.99 & 160 & 13.650 & 0.232 \\
\hline 67.9 & -0.002423 & 0.99 & 151 & 13.577 & 0.257 \\
\hline 68.8 & -0.003759 & 0.99 & 178 & 13.505 & 0.401 \\
\hline 69.7 & -0.003568 & 0.99 & 168 & 13.435 & 0.382 \\
\hline 70.6 & -0.003275 & 0.90 & 117 & 13.364 & 0.353 \\
\hline Average & -0.002916 & 0.99 & 152 & 13.505 & 0.311 \\
\hline
\end{tabular}

\subsection{Well 299-W22-48}

A single-well tracer-dilution test began May 11, 2000 (1143 Pacific daylight time) by introducing $1.99 \mathrm{~L}$ of tracer solution (containing $6.36 \mathrm{~g}$ of bromide) within the 3.70-m well-screen section (70.60 to $74.30 \mathrm{~m}$ below top of casing). The tracer was introduced into the well using a 25 -mm diameter polypropylene tube that was open at a depth setting of $74.2 \mathrm{~m}$ below top of casing. The temperature of the administered tracer solution was $16.3^{\circ} \mathrm{C}$. Following tracer introduction, an equilibration time of $\sim 25$ minutes was observed to allow for dissipation of the displaced water from the tube into the surrounding well-screen column. After the equilibration period, the tube was slowly raised out of the well-water column, causing emplacement of the $1.99 \mathrm{~L}$ of prepared tracer. The tube was then slowly lowered and raised two times within the water column over a 5-minute period to mix the tracer within the well-screen section. The designed concentration within the well screen following mixing of the added tracer was $\sim 200 \mathrm{mg} / \mathrm{L}$.

Following mixing of the tracer solution, an assembly of five bromide probe sensors, using a fixed separation distance of $0.75 \mathrm{~m}$, was lowered into the well. Final depth settings for the five sensors were $71.0,71.75,72.5,73.25$, and $74.0 \mathrm{~m}$ below top of casing. Each sensor had an attached plastic centralizer to keep the sensor approximately centered within the well-screen section. Installation of the assembly was completed in $\sim 25$ minutes, following the mixing of the tracer within the well screen. The concentration within the borehole following emplacement and equilibration of the sensors (i.e., after 60 minutes following initial mixing) ranged between 121 and $165 \mathrm{mg} / \mathrm{L}$ for the various sensor-depth settings. The average initial $\mathrm{C}_{\mathrm{o}}$ within the well screen, based on back-projection of the fitted linear-regression concentration response to time $=0$ minute for the five sensors, was $131 \mathrm{mg} / \mathrm{L}$ (shown in Figure 5.2). The dilution and dissipation within the well screen were observed for a period of 15,730 minutes (10.92 days). At the end of the test, the average concentration was $39.5 \mathrm{mg} / \mathrm{L}$, and ranged between 6 (top) and 93 (bottom) $\mathrm{mg} / \mathrm{L}$ within the well-screen section. The wide-range in bromide concentration is believed reflective of the heterogeneity of the surrounding test interval materials and their varying hydraulic properties. 


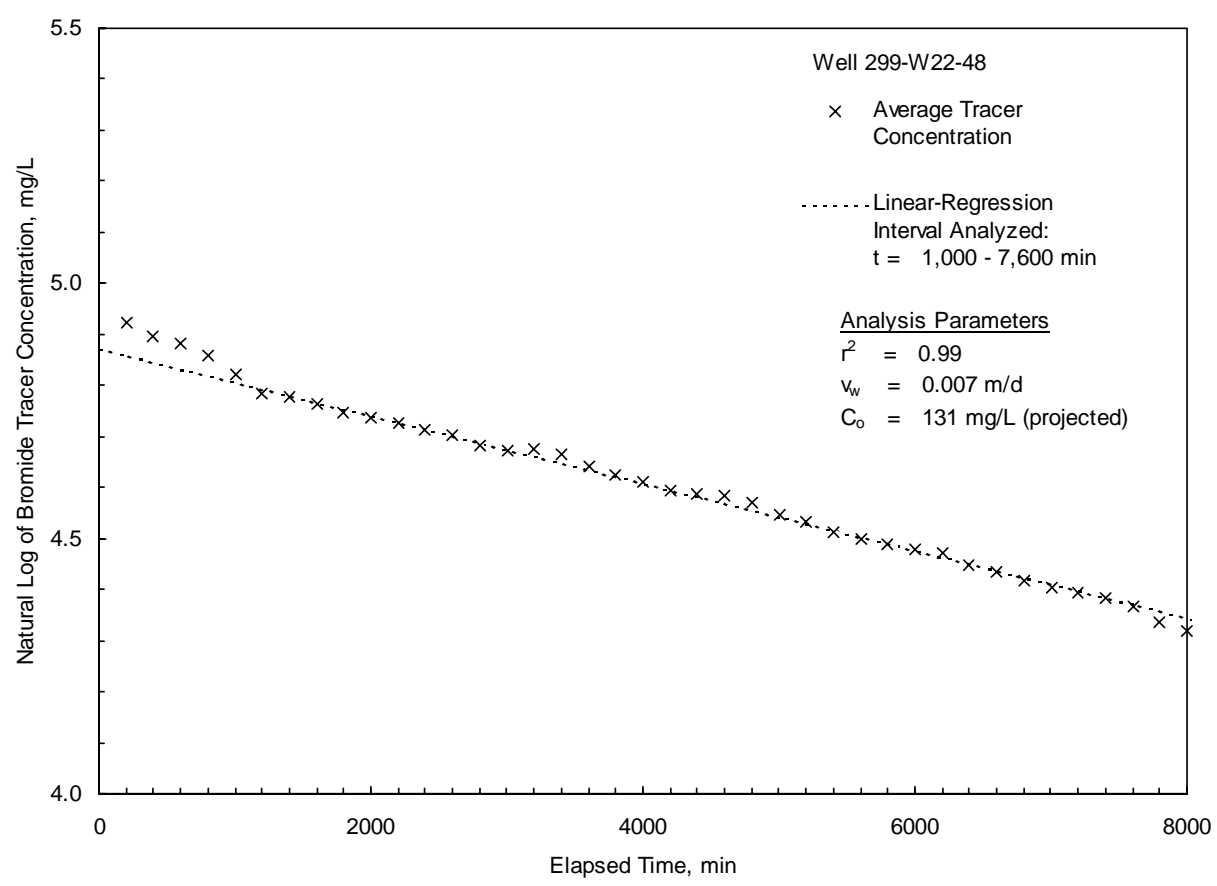

Figure 5.2. Average Tracer-Dilution Test Results Within Well 299-W22-48

Visual examination of the dilution patterns for the various sensor-depth settings indicates no significant vertical flow conditions within the well-screen section. The natural log of bromide concentration versus time depth-setting plots exhibit linear relationships over most of the period of observation. After approximately 7,000 minutes, however, non-linear responses were exhibited for the top two probe depthsettings (71.0 and $71.75 \mathrm{~m})$. The reason for the nonlinear dilution response at these probes sites is not known.

The observed, average dilution pattern versus time can be analyzed to calculate $\mathrm{v}_{\mathrm{w}}$, using Equation (3.3). Linear-regression analysis of the average dilution response (shown in Figure 5.2) within the well screen $\left(r^{2}=0.99\right)$ indicates a slope on the natural log of concentration versus time of $-0.000066 \mathrm{~min}^{-1}$. The calculated average $\mathrm{A} / \mathrm{V}$ relationship for the test interval, taking into account the presence of sensor instrumentation/cable test system cross-sectional area, is $13.505 \mathrm{~m}^{-1}$. Based on these observed and measured parameters, an average calculated $\mathrm{v}_{\mathrm{w}}$ is $0.007 \mathrm{~m} / \mathrm{d}$.

If lateral groundwater-flow conditions occur throughout the entire well, then a comparison of the calculated well velocities at the various sensor-depth settings can provide an assessment of the vertical permeability profile within the well-screen section. A comparison of the average well-flow velocities at the five individual sensor-depth settings indicates the highest in-well flow velocities for the top sensordepth setting ( $71.0 \mathrm{~m}$ btoc). If it can be assumed that a direct correlation between well-flow velocity and aquifer permeability exists for the well/aquifer site, then the highest permeability occurs within the upper part of the well-screen section, and becomes progressively lower with depth within the well screen/test interval section. Table 5.2 summarizes results from the tracer-dilution test at well 299-W22-48. 
Table 5.2. Tracer-Dilution Test Results for Well 299-W22-48

\begin{tabular}{||c|c|c|c|c|c||}
\hline $\begin{array}{c}\text { Well Sensor/ } \\
\text { Depth Setting, } \\
\text { m, below top of } \\
\text { casing }\end{array}$ & $\begin{array}{c}\text { Tracer } \\
\text { Concentration/ } \\
\text { Dilution Slope, } \\
\mathrm{d}(\ln \text { C) dt min }\end{array}$ & $\begin{array}{c}\text { Linear- } \\
\text { Regression } \\
\text { Correlation } \\
\text { Coeficient, }^{2}\end{array}$ & $\begin{array}{c}\text { Projected Initial } \\
\text { Tracer } \\
\text { Concentration, } \\
\mathrm{C}_{\mathrm{o}}, \mathrm{mg} / \mathrm{L}\end{array}$ & $\begin{array}{c}\text { Well } \\
\text { Measurement } \\
\text { Area/Volume } \\
\text { Ratio, } \\
\mathrm{A} / \mathrm{V}, \mathrm{m}^{-1}\end{array}$ & $\begin{array}{c}\text { Calculated } \\
\text { Well-Screen } \\
\text { Flow Velocity, } \\
\mathrm{v}_{\mathrm{w}}, \mathrm{m} / \mathrm{d}\end{array}$ \\
\hline \hline 71.0 & -0.000221 & 0.99 & 113 & 13.650 & 0.023 \\
\hline 71.75 & -0.000092 & 0.99 & 137 & 13.577 & 0.010 \\
\hline 72.5 & -0.000057 & 0.99 & 137 & 13.505 & 0.006 \\
\hline 73.25 & -0.000045 & 0.99 & 142 & 13.435 & 0.005 \\
\hline 74.0 & -0.000015 & 0.90 & 140 & 13.364 & 0.002 \\
\hline Average & -0.000066 & 0.99 & 131 & 13.505 & 0.007 \\
\hline
\end{tabular}

\section{$5.3 \quad$ Well 299-W22-49}

A single-well tracer-dilution test began April 17, 2000 (1240 Pacific daylight time) by introducing 2.35 $\mathrm{L}$ of tracer solution (containing $7.53 \mathrm{~g}$ of bromide) within the 4.51-m well-screen section (67.27 to $71.78 \mathrm{~m}$ below top of casing). The tracer was introduced into the well using a 25 -mm diameter polypropylene tube that was open at a depth setting of $71.8 \mathrm{~m}$ below top of casing. Following tracer introduction, an equilibration time of $\sim 12$ minutes was observed to allow for dissipation of the displaced water from the tube into the surrounding well-screen column. After the equilibration period, the tube was slowly raised out of the well-water column, causing emplacement of the $2.35 \mathrm{~L}$ of prepared tracer. The tube was then slowly lowered and raised two times within the water column over a 5-minute period to mix the tracer within the well-screen section. The designed concentration within the well screen following mixing of the added tracer was $\sim 200 \mathrm{mg} / \mathrm{L}$.

Following mixing of the tracer solution, an assembly of five bromide probe sensors, using a fixed separation distance of $0.9 \mathrm{~m}$, was lowered into the well. Final depth settings for the five sensors were $67.65,68.55,69.45,70.35$, and $71.25 \mathrm{~m}$ below top of casing. Each sensor had an attached plastic centralizer to keep the sensor approximately centered within the well-screen section. Installation of the assembly was completed in $\sim 26$ minutes, following the mixing of the tracer within the well screen. The concentration within the borehole following emplacement and equilibration of the sensors (i.e., after 30 minutes following initial mixing) ranged between 94 and $143 \mathrm{mg} / \mathrm{L}$ for the various sensor-depth settings. The average initial $\mathrm{C}_{\mathrm{o}}$ within the well screen, based on back-projection of the fitted linearregression concentration response to time $=0$ minute for the five sensors, was $145 \mathrm{mg} / \mathrm{L}$ (shown in Figure 5.3). The dilution and dissipation within the well screen were observed for a period of 4,175 minutes (2.90 days). At the end of the test, the average concentration was $4.0 \mathrm{mg} / \mathrm{L}$, and ranged only between 3.5 and $4.4 \mathrm{mg} / \mathrm{L}$ within the well-screen section. 


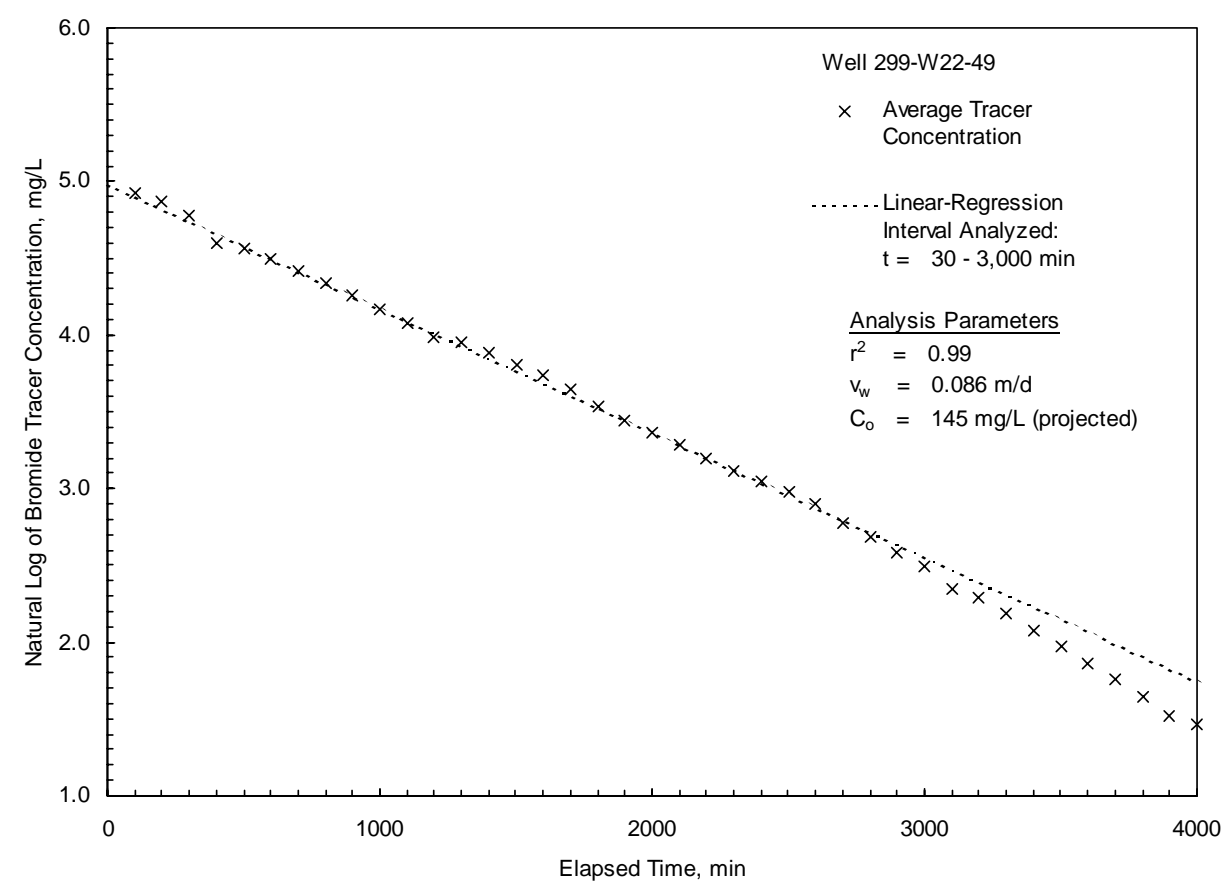

Figure 5.3. Average Tracer-Dilution Test Results Within Well 299-W22-49

Visual examination of the dilution patterns for the various sensor-depth settings indicates a significant, vertical, upward-flow condition within the well-screen section (see Section 8.2). Upward, in-well, flow velocities, ranging between 0.010 and $0.015 \mathrm{~m} / \mathrm{min}$, were calculated by using the arrival times of recognizable signatures between the lower four sensors. The measured velocities are comparable with those reported for well 299-W22-49 by Waldrop and Pearson (2000) $(0.002-0.017 \mathrm{~m} / \mathrm{min}$ detected with a vertical EM flow meter).

As discussed in Section 3.2.1, to be strictly valid, tracer-dilution tests require that no vertical flow conditions exist within the well and that the tracer is continually mixed within the test section. To "simulate" a continuously mixed condition, an average well-screen tracer concentration was calculated, based on averaging the five sensor-depth readings recorded with time. It is not known whether the vertical flow conditions observed within the well are significant enough to affect adversely the results of the tracer-dilution test. The analysis results, therefore, should be viewed as being qualitative estimates.

The observed, average dilution pattern versus time can be analyzed to calculate $\mathrm{v}_{\mathrm{w}}$, using Equation (3.3). Linear-regression analysis of the average dilution response (shown in Figure 5.3) within the well screen $\left(\mathrm{r}^{2}=0.99\right)$ indicates a slope on the natural $\log$ of concentration versus time of $-0.000809 \mathrm{~min}^{-1}$. The calculated average A/V relationship for the test interval, taking into account the presence of sensor instrumentation/cable test system cross-sectional area, is $13.577 \mathrm{~m}^{-1}$. Based on these observed and measured parameters, an average calculated $\mathrm{v}_{\mathrm{w}}$ is $0.086 \mathrm{~m} / \mathrm{d}$. Because lateral groundwater-flow conditions do not occur throughout the entire test interval, an assessment of the vertical permeability profile within the well-screen section (using calculated sensor-depth well-flow velocities) could not be estimated. 


\subsection{Well 299-W22-50}

Two single-well tracer tests (including tracer dilution and pumpback) were conducted at the well site to assess the reproducibility of tracer test results. The first began May 1, 2000 (1005 Pacific daylight time) by introducing $2.22 \mathrm{~L}$ of tracer solution (containing $7.10 \mathrm{~g}$ of bromide) within the 4.30 -m wellscreen section (67.57 to $71.87 \mathrm{~m}$ below top of casing). The tracer was introduced into the well using a 25-mm diameter polypropylene tube that was open at a depth setting of $71.8 \mathrm{~m}$ below top of casing. Following tracer introduction, an equilibration time of $\sim 13$ minutes was observed to allow for dissipation of the displaced water from the tube into the surrounding well-screen column. After the equilibration period, the tube was slowly raised out of the well-water column, causing emplacement of the $2.22 \mathrm{~L}$ of prepared tracer. The tube was then slowly lowered and raised two times within the water column over a 5-minutes period to mix the tracer within the well-screen section. The designed concentration within the well screen following mixing of the added tracer was $\sim 200 \mathrm{mg} / \mathrm{L}$.

Following mixing of the tracer solution, an assembly of five bromide probe sensors, using a fixed separation distance of $0.9 \mathrm{~m}$, was lowered into the well. Final depth settings for the five sensors were $67.9,68.8,69.7,70.6$, and $71.5 \mathrm{~m}$ below top of casing. Each sensor had an attached plastic centralizer to keep the sensor approximately centered within the well-screen section. Installation of the assembly was completed in $\sim 25$ minutes, following the mixing of the tracer within the well screen. The concentration within the borehole following emplacement and equilibration of the sensors (i.e., after 45 minutes following initial mixing) ranged between 113 and $167 \mathrm{mg} / \mathrm{L}$ for the top four sensor-depth settings. A tracer concentration of $70 \mathrm{mg} / \mathrm{L}$ was observed for the lowest sensor depth setting and is attributed to insufficient mixing of the tracer solution at the bottom of the well screen. The average initial $\mathrm{C}_{\mathrm{o}}$ within the well screen, based on back-projection of the fitted linear-regression concentration response to time $=0$ minute for the five sensors, was $190 \mathrm{mg} / \mathrm{L}$ (shown in Figure 5.4). The dilution and dissipation within the well screen were observed for a period of 5,765 minutes (4.00 days). At the end of the test, the average concentration was $5.2 \mathrm{mg} / \mathrm{L}$, and ranged only between 4.8 and $5.8 \mathrm{mg} / \mathrm{L}$ within the well-screen section.

Visual examination of the dilution patterns for the various sensor-depth settings indicates no significant vertical flow conditions within the well-screen section. The natural log of concentration versus time depth-setting plots exhibit linear relationships over the period of observation for all sensor locations. The observed dilution pattern versus time can be analyzed to calculate $\mathrm{v}_{\mathrm{w}}$, using Equation (3.3). Linearregression analysis of the average dilution response (shown in Figure 5.4) for the five sensor-depth settings within the well screen $\left(r^{2}=0.99\right)$ indicates a slope on the natural log of concentration versus time of $-0.000623 \mathrm{~min}^{-1}$. The calculated average A/V relationship for the test interval, taking into account the presence of sensor instrumentation/cable test system cross-sectional area, is $13.505 \mathrm{~m}^{-1}$. Based on these observed and measured parameters, an average calculated $\mathrm{v}_{\mathrm{w}}$ is $0.066 \mathrm{~m} / \mathrm{d}$.

A comparison of the calculated well velocities at the various sensor-depth settings provided essentially the same results. If it can be assumed that a direct correlation between well-flow velocity and aquifer permeability exists for the well/aquifer site, then the observed well-flow velocities suggest that a relatively uniform vertical permeability profile exists within the well-screen section. 


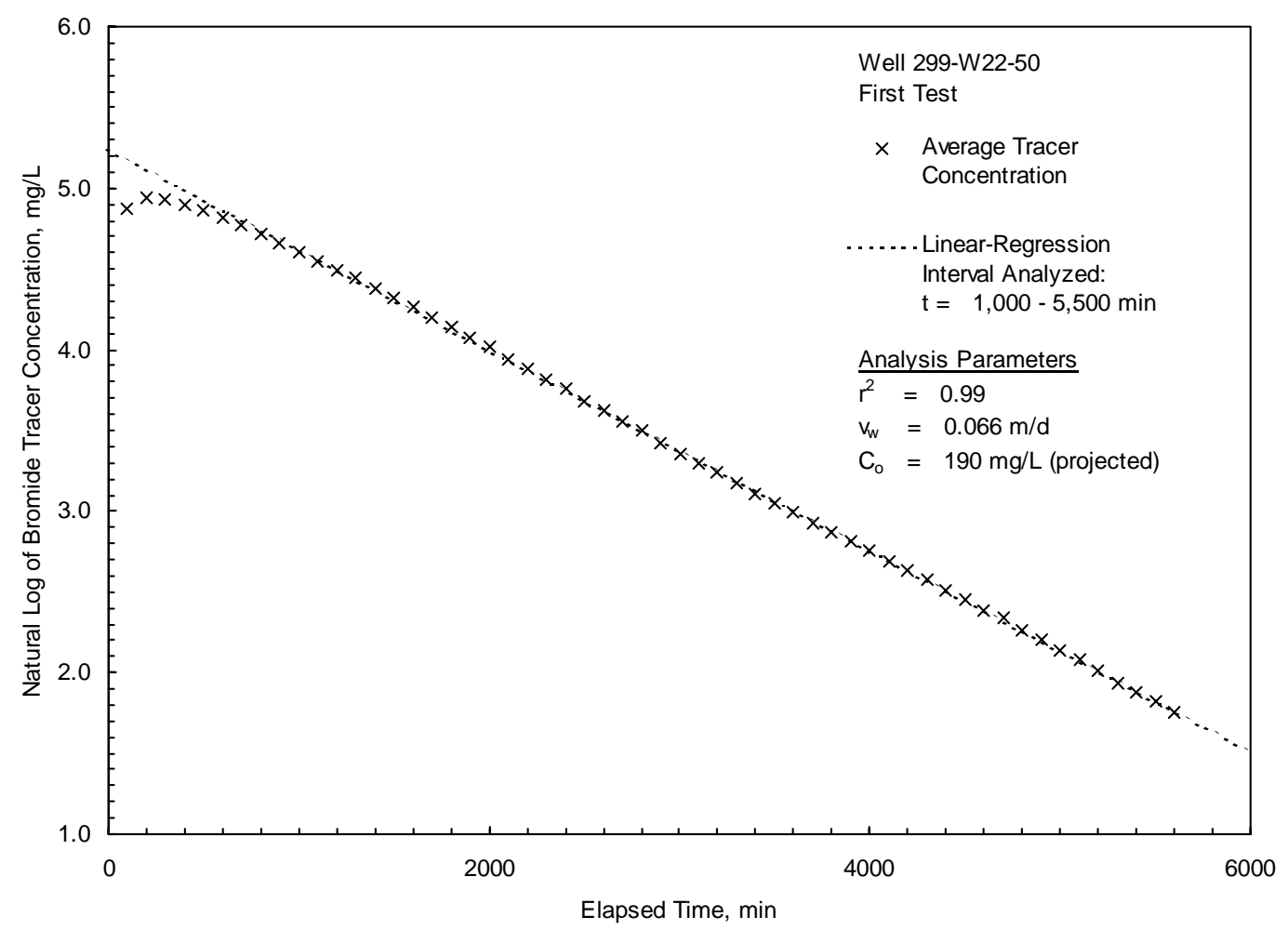

Figure 5.4. Average Tracer-Dilution Test Results for First Test Within Well 299-W22-50

The second test began May 26, 2000 (0955 Pacific daylight time) by introducing 2.22 L of tracer solution (containing $7.10 \mathrm{~g}$ of bromide) within the $4.28-\mathrm{m}$ well-screen section (67.59 to $71.87 \mathrm{~m}$ below top of casing). The tracer was introduced into the well using a $25-\mathrm{mm}$ diameter polypropylene tube that was open at a depth setting of $71.8 \mathrm{~m}$ below top of casing. Following tracer introduction, an equilibration time of $\sim 20$ minutes was observed to allow for dissipation of the displaced water from the tube into the surrounding well-screen column. After the equilibration period, the tube was slowly raised out of the well-water column, causing emplacement of the $2.22 \mathrm{~L}$ of prepared tracer. The tube was then slowly lowered and raised two times within the water column over a 5-minute period to mix the tracer within the well-screen section. The designed concentration within the well screen following mixing of the added tracer was $\sim 200 \mathrm{mg} / \mathrm{L}$.

Following mixing of the tracer solution, an assembly of five bromide probe sensors, using a fixed separation distance of $0.90 \mathrm{~m}$, was lowered into the well. Final depth settings for the five sensors were the same as used for the first tracer-dilution test (i.e., 67.9, 68.8, 69.7, 70.6, and $71.5 \mathrm{~m}$ below top of casing). Each sensor had an attached plastic centralizer to keep the sensor approximately centered within the well-screen section. Installation of the assembly was completed in $\sim 20$ minutes, following the mixing of the tracer within the well screen. The concentration within the borehole following emplacement and equilibration of the sensors (i.e., after 45 minutes following initial mixing) ranged between 124 and $141 \mathrm{mg} / \mathrm{L}$ for the top four sensor-depth settings. A tracer concentration of $68 \mathrm{mg} / \mathrm{L}$ was observed for the lowest sensor depth setting and is attributed to insufficient mixing of the tracer solution at the bottom of 
the well screen. The average initial $\mathrm{C}_{\mathrm{o}}$ within the well screen, based on back-projection of the fitted linear-regression concentration response to time $=0$ minute for the five sensors, was $148 \mathrm{mg} / \mathrm{L}$ (shown in Figure 5.5). The dilution and dissipation within the well screen were observed for a period of 7,240 minutes (5.03 days). At the end of the test, the average concentration was $6.5 \mathrm{mg} / \mathrm{L}$ within the well-screen section.

Visual examination of the dilution patterns for the various sensor-depth settings indicates no significant vertical flow conditions within the well-screen section. The natural log of concentration versus time depth-setting plots exhibit linear relationships over the period of observation for all sensor locations. The observed dilution pattern versus time can be analyzed to calculate $v_{w}$, using Equation (3.3). Linearregression analysis of the average dilution response (shown in Figure 5.5) for the five sensor-depth settings within the well screen $\left(r^{2}=0.99\right)$ indicates a slope on the natural log of concentration versus time of $-0.000500 \mathrm{~min}^{-1}$. The calculated average $\mathrm{A} / \mathrm{V}$ relationship for the test interval, taking into account the presence of sensor instrumentation/cable test system cross-sectional area, is $13.505 \mathrm{~m}^{-1}$. Based on these observed and measured parameters, an average calculated $\mathrm{v}_{\mathrm{w}}$ is $0.046 \mathrm{~m} / \mathrm{d}$. The calculated $\mathrm{v}_{\mathrm{w}}$ is $\sim 30 \%$ lower than that calculated for the first tracer-dilution test. It is not known whether the difference in the calculated $\mathrm{v}_{\mathrm{w}}$ can be ascribed to changes in actual test site conditions (e.g., hydraulic gradient) or due to insensitivities of the test.

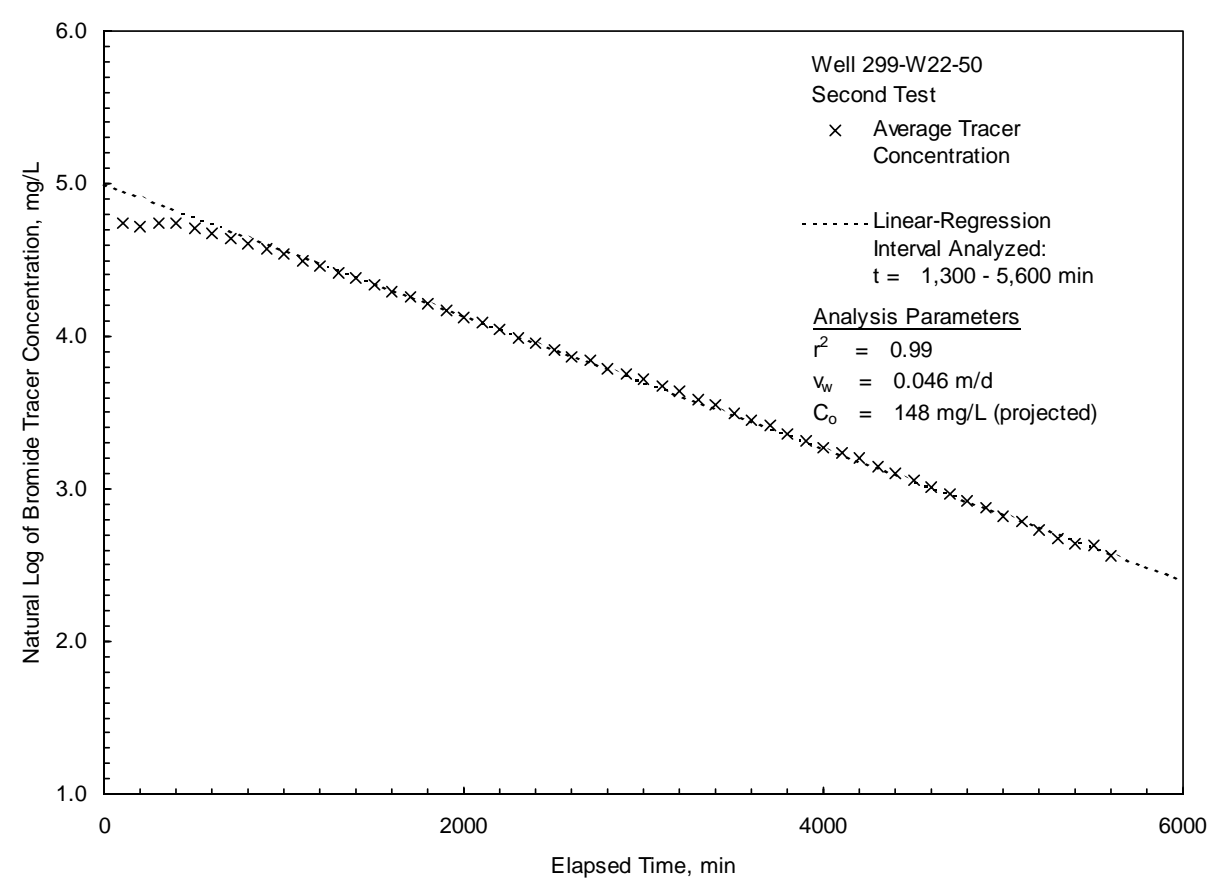

Figure 5.5. Average Tracer-Dilution Test Results for Second Test Within Well 299-W22-50 
As during the first tracer-dilution test, a comparison of the calculated well velocities at the various sensor-depth settings provided essentially the same results. If it can be assumed that a direct correlation between well-flow velocity and aquifer permeability exists for the well/aquifer site, then the observed well-flow velocities suggest that a relatively uniform vertical permeability profile exists within the wellscreen section.

\subsection{Well 699-43-44}

A single-well tracer-dilution test began April 4, 2000 (1425 Pacific daylight time) by introducing 2.52 L of tracer solution (containing $8.07 \mathrm{~g}$ of bromide) within the 4.86-m well-screen section (54.11 to $58.97 \mathrm{~m}$ below top of casing). The tracer was introduced into the well using a $25-\mathrm{mm}$ diameter polypropylene tube that was open at a depth setting of $58.5 \mathrm{~m}$ below top of casing. Following tracer introduction, an equilibration time of $\sim 14$ minutes was observed to allow for dissipation of the displaced water from the tube into the surrounding well-screen column. After the equilibration period, the tube was slowly raised out of the well-water column, causing emplacement of the $2.52 \mathrm{~L}$ of prepared tracer. The tube was then slowly lowered and raised two times within the water column over a 5-minute period to mix the tracer within the well-screen section. The designed concentration within the well screen following mixing of the added tracer was $\sim 200 \mathrm{mg} / \mathrm{L}$.

Following mixing of the tracer solution, an assembly of five bromide probe sensors, using a fixed separation distance of $0.9 \mathrm{~m}$, was lowered into the well. Final depth settings for the five sensors were $54.9,55.8,56.7,57.6$, and $58.5 \mathrm{~m}$ below top of casing. Each sensor had an attached plastic centralizer to keep the sensor approximately centered within the well-screen section. Installation of the assembly was completed in $\sim 31$ minutes, following the mixing of the tracer within the well screen. The concentration within the borehole following emplacement and equilibration of the sensors (i.e., after 40 minutes following initial mixing) ranged between 173 and $205 \mathrm{mg} / \mathrm{L}$ for the various sensor-depth settings. The average initial $\mathrm{C}_{\mathrm{o}}$ within the well screen, based on back-projection of the fitted linear-regression concentration response to time $=0$ minute for the five sensors, was $204 \mathrm{mg} / \mathrm{L}$. The dilution and dissipation within the well screen were observed for a period of 4,045 minutes (2.81 days). At the end of the test, the average concentration was $0.75 \mathrm{mg} / \mathrm{L}$, and ranged only between 0.3 and $1.8 \mathrm{mg} / \mathrm{L}$ within the well-screen section.

Visual examination of the dilution patterns for the various sensor-depth settings indicates a slight, vertical, upward flow condition within the well-screen section (see Section 8.2). Upward, in-well, flow velocities, ranging between 0.008 and $0.015 \mathrm{~m} / \mathrm{min}$, were calculated by using the arrival times of recognizable tracer signatures between the top four sensors. Although no consistent, in-well vertical flow direction was reported across the entire well-screen section using the vertical EM flow meter (Waldrop and Pearson 2000), a maximum upward flow velocity of $0.015 \mathrm{~m} / \mathrm{min}$ was recorded within the blank well-screen section ( $\sim 56 \mathrm{~m}$ below top of casing).

As previously discussed, to be strictly valid, tracer-dilution tests require that no vertical flow conditions exist within the well and that the tracer is continually mixed within the test section. To "simulate" a continuously mixed condition, an average well-screen tracer concentration was calculated, based on averaging the five sensor-depth readings recorded with time. It is not known whether the 
vertical flow conditions observed within the well are significant enough to affect adversely the results of the tracer-dilution test. The analysis results, therefore, should be viewed as being qualitative estimates.

The observed, average dilution pattern versus time can be analyzed to calculate $\mathrm{v}_{\mathrm{w}}$, using Equation (3.3). Linear-regression analysis of the average dilution response (shown in Figure 5.6) within the well screen $\left(r^{2}=0.99\right)$ indicates a slope on the natural log of concentration versus time of $-0.001688 \mathrm{~min}^{-1}$. The calculated average A/V relationship for the test interval, taking into account the presence of sensor instrumentation/cable test system cross-sectional area, is $13.505 \mathrm{~m}^{-1}$. Based on these observed and measured parameters, an average calculated $\mathrm{v}_{\mathrm{w}}$ is $0.180 \mathrm{~m} / \mathrm{d}$. Because of the observed, in-well, vertical flow condition, the analysis result should be viewed as being a qualitative estimate. In addition because lateral groundwater-flow conditions do not occur throughout the entire test interval, an assessment of the vertical permeability profile within the well-screen section (using calculated sensordepth well-flow velocities) could not be estimated.

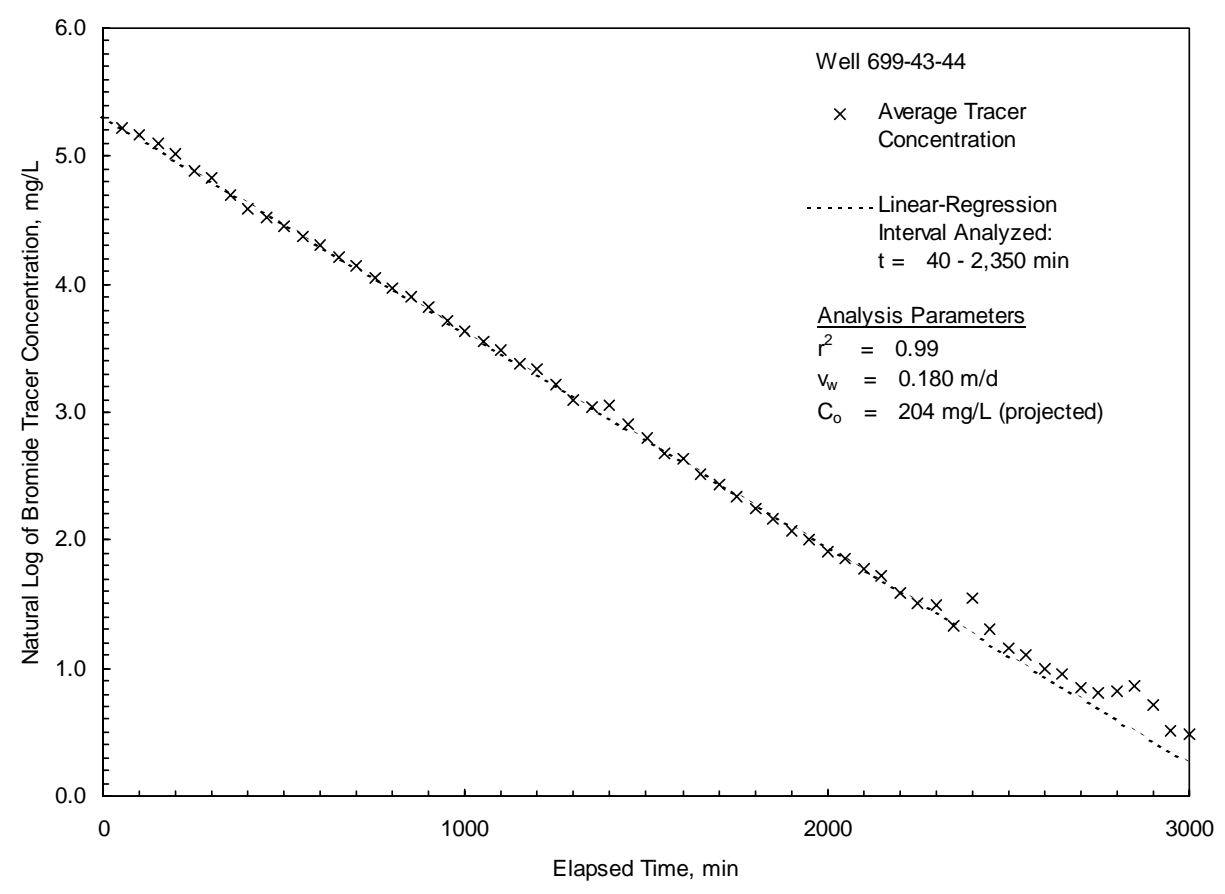

Figure 5.6. Average Tracer-Dilution Test Results Within Well 699-43-44 


\subsection{Tracer-Pumpback Test Results}

Results from the bromide tracer-pumpback phase of the single-well tracer testing were analyzed using the methods described in Section 3.2.2. As noted previously, the analytical assumptions of full aquifer penetration and rapid pulse injection into the aquifer were not met with the given field test conditions. Because of these test deficiencies, the estimates derived from the pumpback test for effective porosity, $\mathrm{n}_{\mathrm{e}}$, and average groundwater-flow velocity within the aquifer, $v_{a}$, should be used qualitatively only. Future efforts will be directed to improve the estimates for $n_{e}$ and $v_{a}$ by accounting for these effects. A description of the information pertinent to the tracer-pumpback test performed in four wells is provided below.

\subsection{Well 299-W15-41}

After a 2,714-minute (1.88-day) tracer-drift period, $\mathrm{t}_{\mathrm{d}}$, recovery of the tracer from well 299-W15-14 and the surrounding aquifer was initiated with a constant-rate pumping test beginning on May 10, 2000 (1020 Pacific daylight time). Tracer recovery was terminated after 150 minutes. The average tracer concentration within the well was $1.3 \mathrm{mg} / \mathrm{L}$ at the beginning of pumpback. Given the calculated well screen and sandpack volumes of 37.1 and $31.4 \mathrm{~L}$, respectively, $7.73 \mathrm{~g}$ of the $7.8 \mathrm{~g}$ of tracer initially emplaced in the well are estimated to have been transported within the aquifer. After minor flow adjustments were completed during the first 4 minutes of the test, pumping rates remained relatively constant during tracer pumpback, ranging between 59.6 and $64.2 \mathrm{~L} / \mathrm{min}$ (average $60.4 \mathrm{~L} / \mathrm{min}$ ) for the entire test. An estimated $4.6 \mathrm{~g}$ of the total $7.8 \mathrm{~g}$ of tracer (i.e., 59\%) emplaced in the well were recovered during the constant-rate pumping test. The pumping time, $\mathrm{t}_{\mathrm{p}}$, to recover $50 \%$ of the tracer emplaced within the aquifer (accounting for transit time during pumping from the well screen to land surface) is estimated at 109.0 minutes. The time required to recover the center of the tracer mass that was transported within the aquifer was used in Equations (3.8) and (3.9) to calculate $\mathrm{n}_{\mathrm{e}}$ and $\mathrm{v}_{\mathrm{a}}$. As indicated in the equations, information pertaining to hydraulic conductivity, K, hydraulic gradient, I, aquifer thickness, b, and pumping rate, $\mathrm{Q}$, must also be known for the test well site.

A K value of $19.62 \mathrm{~m} / \mathrm{d}$ was used, which is based on results from the constant-rate pumping test for the test well (i.e., during tracer pumpback). The calculated local I value of $0.00129 \mathrm{~m} / \mathrm{m}$ and flow direction of 286 degrees ( 0 degrees East; 90 degrees North) were determined using trend-surface analysis for water-level elevation measurement periods from well 299-W15-41 and four nearby monitor wells (299-W14-5, 299-W14-6, 299-W14-14, and 299-W15-40) immediately prior to initiating tracer testing on May 8, 2000. The I value is consistent with that listed in Table A.2 of Hartman et al. (2000) $(0.001 \mathrm{~m} / \mathrm{m}$ for Waste Management Area TX-TY). The b value of $57.6 \mathrm{~m}$ was calculated directly from projection of known geologic relationships at nearby wells.

Based on these input parameters and tracer-pumpback results, $\mathrm{n}_{\mathrm{e}}$ and $\mathrm{v}_{\mathrm{a}}$ are estimated to be 0.068 and $0.374 \mathrm{~m} / \mathrm{d}$, respectively. Based on the observed tracer-pumpback profile (Figure 6.1) and calculated radial distance traveled within the aquifer by the tracer's center of mass (i.e., product of $v_{a}$ and $t_{d}=$ $0.70 \mathrm{~m}$ ), the results of pumpback are reflective of local, near-well, aquifer conditions and may be susceptible to the adverse wellbore effects discussed in Section 3.2.2. 


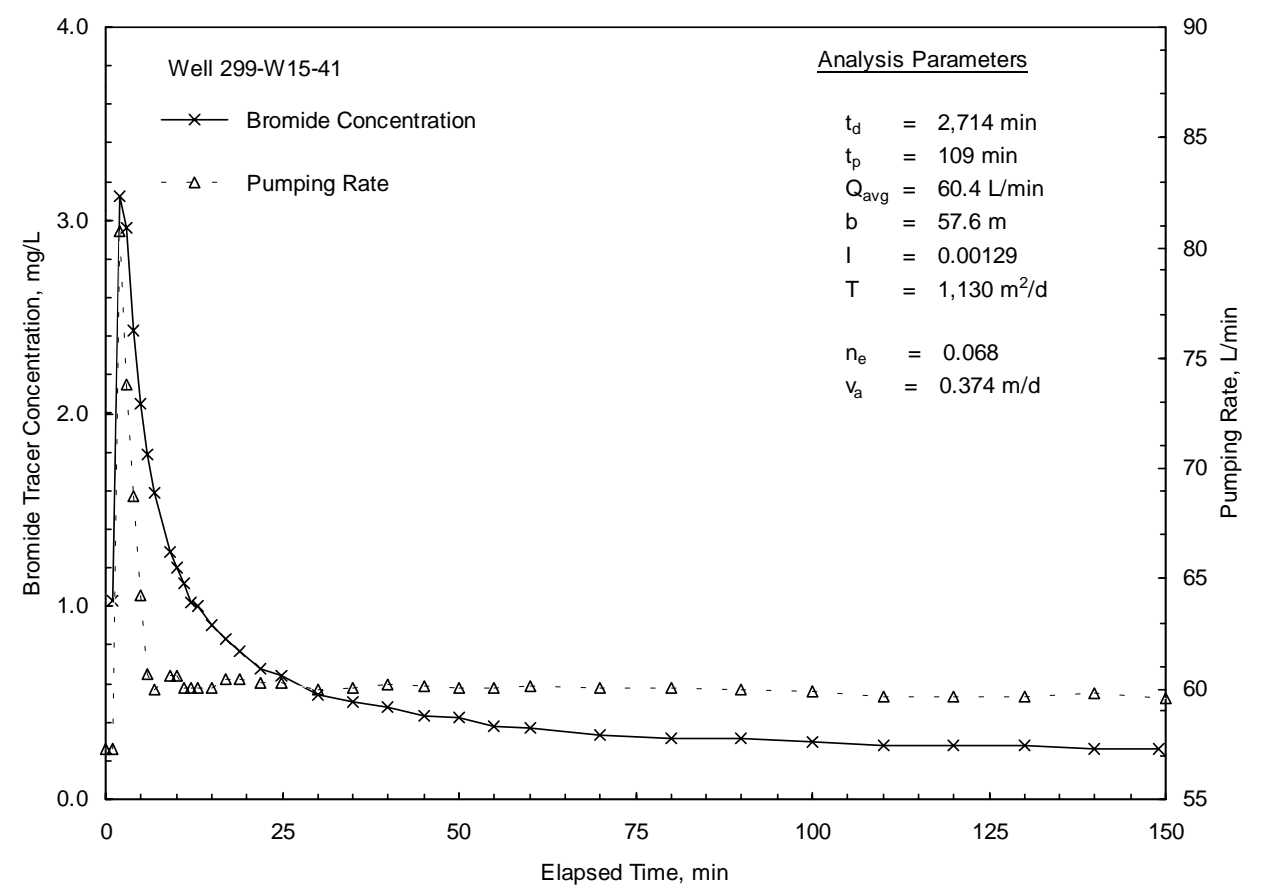

Figure 6.1. Tracer-Pumpback Test Results for Well 299-W15-41

Table 6.1 summarizes the pertinent information associated with the tracer-pumpback results for well 299-W15-41. The hydraulic property estimates obtained for the tracer-pumpback results fall within the reported range $\left(\mathrm{n}_{\mathrm{e}}=0.1\right.$ to $0.3 ; \mathrm{v}_{\mathrm{a}}=0.2$ to $\left.0.6 \mathrm{~m} / \mathrm{d}\right)$ for these parameters in Table A.2 of Hartman et al. (2000) for Waste Management Area TX-TY. It should be noted, however, that the property ranges listed by Hartman et al. (2000) are not based on direct field test results and are either assumed values (i.e., for $\mathrm{n}_{\mathrm{e}}$ ) or calculated, based on the Darcy groundwater-flow equation relationship (i.e., to estimate $\mathrm{v}_{\mathrm{a}}$ ).

\subsection{Well 299-W22-48}

After a 15,730-minute (10.92-day) $t_{d}$, recovery of the tracer from well 299-W22-48 and the surrounding aquifer was initiated with a constant-rate pumping test beginning on May 22, 2000 (1020 Pacific daylight time). Tracer recovery was terminated after 220 minutes. The average tracer concentration within the well was $39.5 \mathrm{mg} / \mathrm{L}$ at the beginning of pumpback. Because of the relatively high in-well concentrations, $4.61 \mathrm{~g}$ of the $6.36 \mathrm{~g}$ of tracer initially emplaced in the well are estimated to have been transported within the aquifer. After minor flow adjustments were completed during the first 5 minutes of the test, pumping rates remained relatively constant during tracer pumpback, ranging between 6.83 and $7.14 \mathrm{~L} / \mathrm{min}$ (average $6.96 \mathrm{~L} / \mathrm{min}$ ) for the entire test. An estimated $4.12 \mathrm{~g}$ of the total $6.36 \mathrm{~g}$ of tracer (i.e., $65 \%$ ) emplaced in the well were recovered during the constant-rate pumping test. The $\mathrm{t}_{\mathrm{p}}$ to recover $50 \%$ of the tracer emplaced within the aquifer (accounting for transit time during pumping from the well screen 
Table 6.1. Tracer-Pumpback Test Summary

\begin{tabular}{|c|c|c|c|c|c|c|c|c|c|}
\hline \multirow[b]{2}{*}{$\begin{array}{c}\text { Waste } \\
\text { Management } \\
\text { Area }\end{array}$} & \multirow[b]{2}{*}{ Well } & \multicolumn{4}{|c|}{ Hydrologic Characterization Data } & \multicolumn{4}{|c|}{ Tracer-Pumpback Test } \\
\hline & & $\begin{array}{c}\text { Aquifer } \\
\text { Thickness, } \\
\text { b, m }\end{array}$ & $\begin{array}{c}\text { Pumping } \\
\text { Rate, } \\
\text { Q, L/min }\end{array}$ & $\begin{array}{l}\text { Hydraulic } \\
\text { Gradient, } \\
\text { I, m/m }\end{array}$ & $\begin{array}{c}\text { Transmissivity, } \\
\mathrm{T}, \mathrm{m}^{2} / \mathrm{d}\end{array}$ & $\begin{array}{l}\text { Tracer } \\
\text { Drift } \\
\text { Time, } \\
\mathrm{t}_{\mathrm{d}}, \text { min }\end{array}$ & $\begin{array}{c}\text { Tracer } \\
\text { Recovery } \\
\text { Time, } \\
\mathrm{t}_{\mathrm{p}}, \mathrm{min}\end{array}$ & $\begin{array}{c}\text { Effective } \\
\text { Porosity, } \\
\mathrm{n}_{\mathrm{e}}\end{array}$ & $\begin{array}{c}\text { Groundwater- } \\
\text { Flow } \\
\text { Velocity, } \\
\mathrm{v}_{\mathrm{a}}, \mathrm{m} / \mathrm{d}\end{array}$ \\
\hline TX-TY & 299-W15-41 & 57.6 & 60.4 & 0.00129 & 1130 & 2,714 & 109.0 & 0.068 & 0.374 \\
\hline \multirow{4}{*}{ S-SX } & 299-W22-48 & 70.1 & 6.96 & 0.0018 & 125 & 15,730 & 159.1 & 0.257 & 0.013 \\
\hline & 299-W22-49 & 72.5 & 42.2 & 0.00206 & 550 & 4,175 & 14.9 & $\begin{array}{l}\mathrm{VF}^{(c)} \\
(0.671)\end{array}$ & $\begin{array}{l}\mathrm{VF}^{(\mathrm{c})} \\
(0.022)\end{array}$ \\
\hline & \multirow[t]{2}{*}{ 299-W22-50 } & \multirow[t]{2}{*}{73.5} & $\begin{array}{c}28.5 \\
\text { (Test \#1) }\end{array}$ & 0.00204 & 385 & 5,765 & 43.4 & 0.354 & 0.030 \\
\hline & & & $\begin{array}{c}29.2 \\
\text { (Test \#2) }\end{array}$ & 0.00206 & 385 & 7,240 & 88.0 & 0.272 & 0.040 \\
\hline B-Pond & $699-43-44$ & 5.2 & 14.5 & - & 8.85 & 4,045 & - & $\mathrm{VF}^{(\mathrm{b})}$ & $\mathrm{VF}^{(\mathrm{b})}$ \\
\hline
\end{tabular}

to land surface) is estimated at 159.1 minutes. The time required to recover the center of the tracer mass that was transported within the aquifer was used in Equations (3.8) and (3.9) to calculate $n_{e}$ and $v_{a}$. As indicated in the equations, information pertaining to K, I, b, and Q must also be known for the test well site.

A K value of $1.81 \mathrm{~m} / \mathrm{d}$ was used, which is based on results from the constant-rate pumping test for the test well (i.e., during tracer pumpback). The local calculated I value of $0.0018 \mathrm{~m} / \mathrm{m}$ and flow direction of 2 degrees ( 0 degrees East; 90 degrees North) were determined using trend-surface analysis for water-level elevation measurement from two nearby monitor wells (299-W22-45 and 299-W23-13) and the test well, which were taken immediately prior to tracer testing. The I value is consistent with that listed in Table A.2 of Hartman et al. (2000) $(0.0016 \mathrm{~m} / \mathrm{m}$ for Waste Management Area S-SX). The b value of $70.1 \mathrm{~m}$ was calculated directly from projection from known geologic relationships at nearby wells.

Based on these input parameters and tracer-pumpback results, $\mathrm{n}_{\mathrm{e}}$ and $\mathrm{v}_{\mathrm{a}}$ were estimated to be 0.257 and $0.013 \mathrm{~m} / \mathrm{d}$, respectively. Based on the observed tracer-pumpback profile (Figure 6.2) and calculated radial distance traveled within the aquifer by the tracer's center of mass (i.e., product of $\mathrm{v}_{\mathrm{a}}$ and $\mathrm{t}_{\mathrm{d}}=$ $0.15 \mathrm{~m}$ ), the results of pumpback are reflective of local, near-well, aquifer conditions and may be susceptible to the adverse wellbore effects discussed in Section 3.2.2.

Table 6.1 summarizes the pertinent information associated with the tracer-pumpback results for well 299-W22-48. The hydraulic property estimates obtained for the tracer-pumpback results fall within the reported range $\left(\mathrm{n}_{\mathrm{e}}=0.1\right.$ to $0.3 ; \mathrm{v}_{\mathrm{a}}=0.0023$ to $\left.0.43 \mathrm{~m} / \mathrm{d}\right)$ for these parameters in Table A.2 of Hartman et al. (2000) for Waste Management Area S-SX. It should be noted, however, that the property ranges listed by Hartman et al. (2000) are not based on direct field test results and are either assumed values (i.e., for $\mathrm{n}_{\mathrm{e}}$ ) or calculated, based on the Darcy groundwater-flow equation relationship (i.e., to estimate $\mathrm{v}_{\mathrm{a}}$ ). 


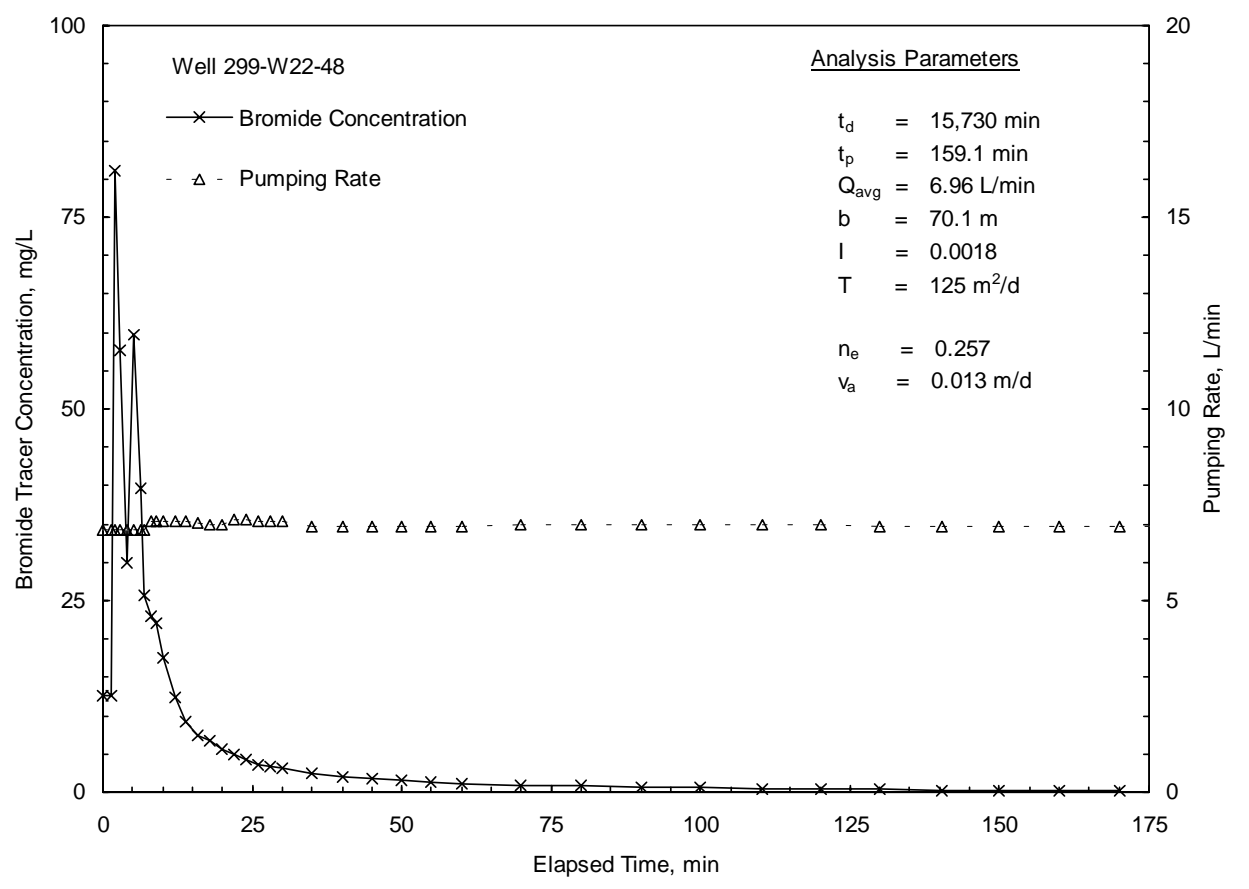

Figure 6.2. Tracer-Pumpback Test Results for Well 299-W22-48

\subsection{Well 299-W22-49}

After a 4,175-minute (2.90-day) $t_{d}$, recovery of the tracer from well 299-W22-49 and the surrounding aquifer was initiated with a constant-rate pumping test beginning on April 20, 2000 (1015 Pacific daylight time). Tracer recovery was terminated after 195 minutes. The average tracer concentration within the well was $4.0 \mathrm{mg} / \mathrm{L}$ at the beginning of pumpback. Because of the low in-well concentration, $7.32 \mathrm{~g}$ of the $7.53 \mathrm{~g}$ of tracer initially emplaced in the well are estimated to have been transported within the aquifer. After minor flow adjustments were completed during the first 5 minutes of the test, pumping rates remained relatively constant during tracer pumpback, ranging between 48.2 and $49.1 \mathrm{~L} / \mathrm{min}$ (average 48.9 $\mathrm{L} / \mathrm{min}$ ) for the entire test. An estimated $6.0 \mathrm{~g}$ of the total $7.53 \mathrm{~g}$ of tracer (i.e., $80 \%$ ) emplaced in the well were recovered during the constant-rate pumping test. The $t_{p}$ to recover $50 \%$ of the tracer emplaced within the aquifer (accounting for transit time during pumping from the well screen to land surface) is estimated at 14.9 minutes. The time required to recover the center of the tracer mass that was transported within the aquifer was used in Equations (3.8) and (3.9) to calculate $\mathrm{n}_{\mathrm{e}}$ and $\mathrm{v}_{\mathrm{a}}$. As indicated in the equations, information pertaining to $\mathrm{K}, \mathrm{I}, \mathrm{b}$, and Q must also be known for the test well site.

A K value of $7.17 \mathrm{~m} / \mathrm{d}$ was used, which is based on results from the constant-rate pumping test for the test well (i.e., during tracer pumpback). The local calculated I value of $0.00206 \mathrm{~m} / \mathrm{m}$ and flow direction of 1 degree ( 0 degrees East; 90 degrees North) were determined using trend-surface analysis for waterlevel elevation measurements from well 299-W22-49 and three nearby monitor wells (299-W22-50, 299W23-14, and 299-W23-15) 30 days after termination of tracer pumpback. The I value is consistent with that listed in Table A.2 of Hartman et al. (2000) $(0.0016 \mathrm{~m} / \mathrm{m}$ for Waste Management Area S-SX). The b value of 72.5 is calculated directly from projection from known geologic relationships at nearby wells. 
Based on these input parameters and tracer-pumpback results, $\mathrm{n}_{\mathrm{e}}$ and $\mathrm{v}_{\mathrm{a}}$ are estimated to be 0.671 and $0.022 \mathrm{~m} / \mathrm{d}$, respectively (Figure 6.3). Because of the vertical flow conditions that were observed during the tracer-dilution test, the estimated values from the tracer-pumpback test should be considered highly questionable, particularly the estimate for $n_{e}$ (which is not a realistic value). This is attributed to the fact that the part of the aquifer within the well-screen section receiving the tracer during dilution/ injection is significantly different than the part of the aquifer providing groundwater during pumpback. Although the estimate for $\mathrm{v}_{\mathrm{a}}$ falls within the range listed in Table A.2 of Hartman et al. (2000) for Waste Management Area S-SX (i.e., $\mathrm{v}_{\mathrm{a}}=0.0023$ to $0.43 \mathrm{~m} / \mathrm{d}$ ), it is also likely influenced significantly by the effects of vertical flow during the tracer-dilution test and should be considered questionable. The pumpback analysis results for well 299-W22-49 are included in Table 6.1 for comparison purposes only.

\subsection{Well 299-W22-50}

Two single-well tracer tests (including tracer dilution and pumpback) were conducted at the well site to assess the reproducibility of tracer test results. For the first test, after a 5,765-minute (4.00-day) $t_{d}$, recovery of the tracer from well 299-W22-50 and the surrounding aquifer was initiated with a constantrate pumping test beginning on May 5, 2000 (1010 Pacific daylight time). Tracer recovery was terminated after 200 minutes. The average tracer concentration within the well-screen section was $5.2 \mathrm{mg} / \mathrm{L}$ at the beginning of pumpback, indicating that $6.83 \mathrm{~g}$ of the $7.10 \mathrm{~g}$ were emplaced within the aquifer. After

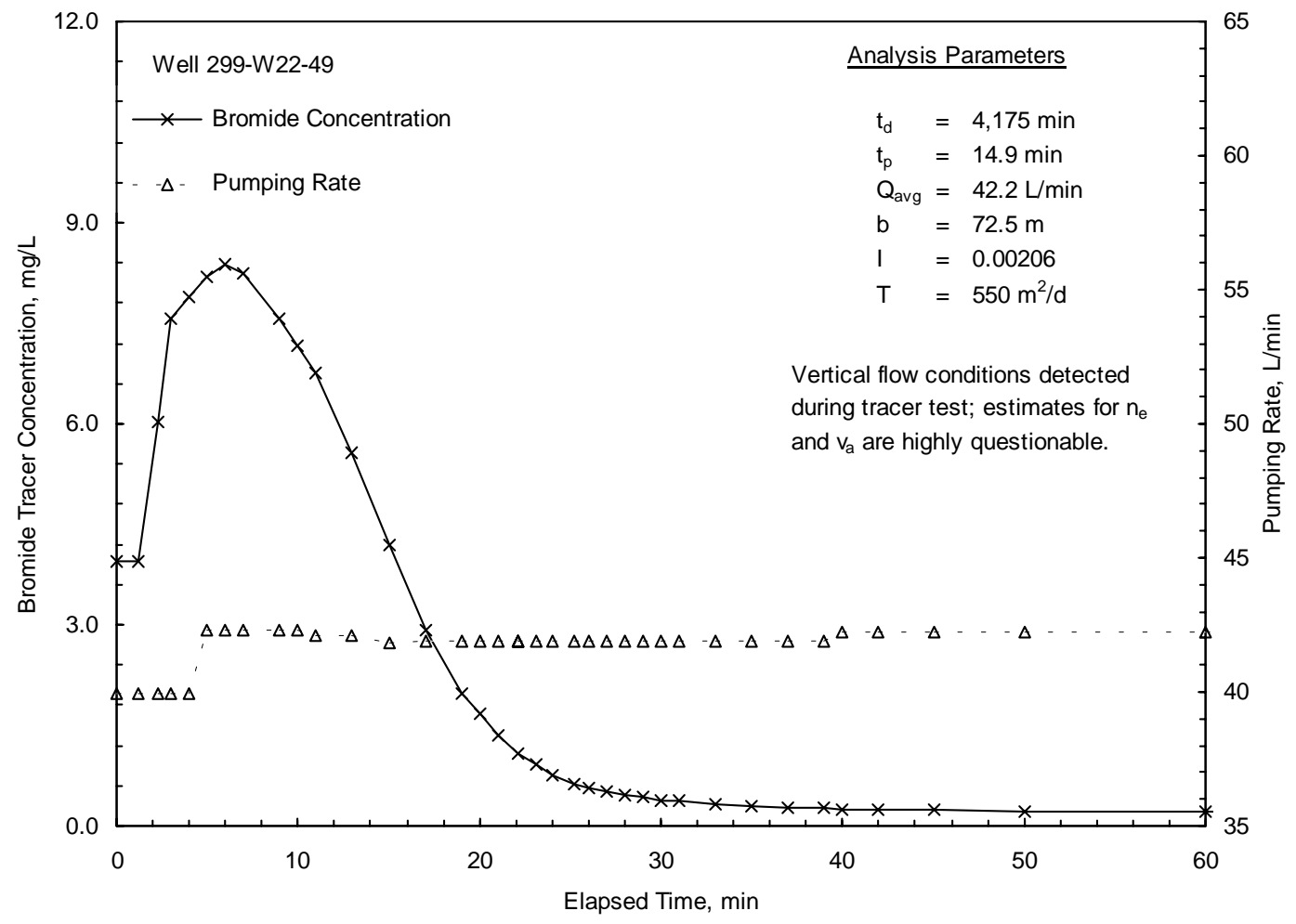

Figure 6.3. Tracer-Pumpback Test Results for Well 299-W22-49 
minor flow adjustments were completed during the first 5 minutes of the test, pumping rates remained relatively constant during tracer pumpback, ranging between 28.0 and $28.5 \mathrm{~L} / \mathrm{min}$ (average $28.5 \mathrm{~L} / \mathrm{min}$ ) for the entire test. An estimated $4.70 \mathrm{~g}$ of the total $7.10 \mathrm{~g}$ of tracer (i.e., $66 \%$ ) emplaced in the well were recovered during the constant-rate pumping test. The $t_{p}$ to recover $50 \%$ of the tracer emplaced within the aquifer (accounting for transit time during pumping from the well screen to land surface) is estimated at 43.4 minutes. The time required to recover the center of the tracer mass that was transported within the aquifer was used in Equations (3.8) and (3.9) to calculate $\mathrm{n}_{\mathrm{e}}$ and $\mathrm{v}_{\mathrm{a}}$. As indicated in the equations, information pertaining to $\mathrm{K}, \mathrm{I}, \mathrm{b}$, and Q must also be known for the test well site.

A K value of $5.24 \mathrm{~m} / \mathrm{d}$ was used, which is based on results from the constant-rate pumping test for the test well (i.e., during tracer pumpback). The calculated local I value of $0.00204 \mathrm{~m} / \mathrm{m}$ and flow direction of 359 degrees ( 0 degrees East; 90 degrees North) were determined using trend-surface analysis for water-level elevation measurements from well 299-W22-50 and three nearby monitor wells (299-W22-49, 299-W23-14, and 299-W23-15) twelve days after termination of tracer pumpback (i.e., on May 17, 2000). A hydraulic gradient could not be calculated for the four well set during actual tracer testing, due to the inaccessibility of well 2-W23-15 during this period. The I value is consistent with that listed in Table A.2 of Hartman et al. (2000) $(0.0016 \mathrm{~m} / \mathrm{m}$ for Waste Management Area S-SX). The b value of 73.5 as calculated directly from known geologic relationships at the well site.

Based on these input parameters and tracer-pumpback results, $\mathrm{n}_{\mathrm{e}}$ and $\mathrm{v}_{\mathrm{a}}$ are estimated to be 0.354 and $0.030 \mathrm{~m} / \mathrm{d}$, respectively (Figure 6.4). Based on the observed tracer-pumpback profile and calculated

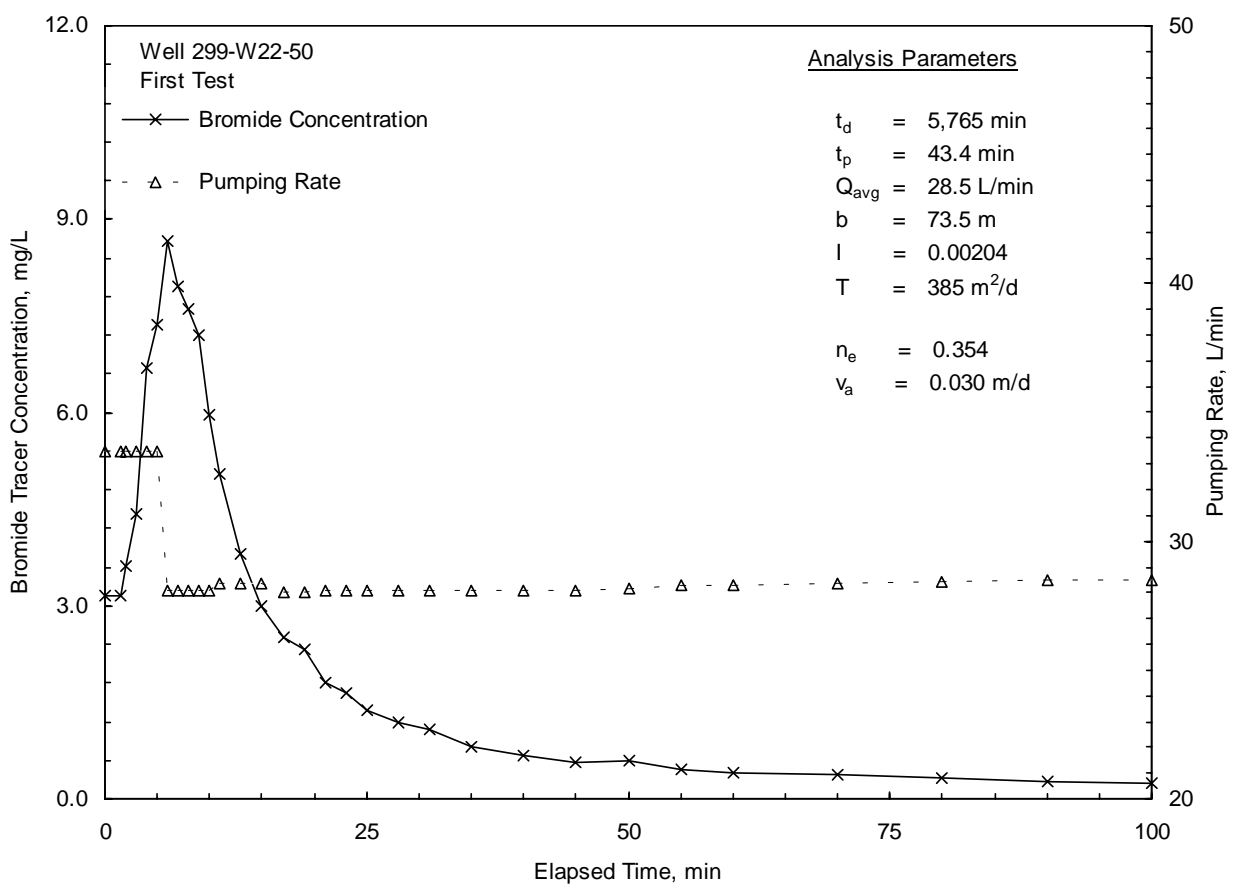

Figure 6.4. Tracer-Pumpback Test Results for First Test, Well 299-W22-50 
radial distance traveled within the aquifer by the tracer's center of mass (i.e., product of $\mathrm{v}_{\mathrm{a}}$ and $\mathrm{t}_{\mathrm{d}}=$ $0.12 \mathrm{~m}$ ), the results of the tracer pumpback reflect local, near-well, aquifer conditions and may be susceptible to the adverse wellbore effects discussed in Section 3.2.2.

For the second test, after a 7,240-minute (5.03-day) $t_{d}$, recovery of the tracer from well 299-W22-50 and the surrounding aquifer was initiated with a constant-rate pumping test beginning on May 31, 2000 (1035 Pacific daylight time). Tracer recovery was terminated after 121 minutes. The average tracer concentration within the well-screen section was $6.5 \mathrm{mg} / \mathrm{L}$ at the beginning of pumpback, indicating that $6.77 \mathrm{~g}$ of the $7.10 \mathrm{~g}$ were emplaced within the aquifer. After minor flow adjustments were completed during the first minutes of the test, pumping rates remained relatively constant during tracer pumpback, ranging between 28.9 and $30.0 \mathrm{~L} / \mathrm{min}$ (average $29.2 \mathrm{~L} / \mathrm{min}$ ) for the entire test. An estimated $3.92 \mathrm{~g}$ of the total $7.10 \mathrm{~g}$ of tracer (i.e., 55\%) emplaced in the well were recovered during the constant-rate pumping test. The $\mathrm{t}_{\mathrm{p}}$ to recover $50 \%$ of the tracer emplaced within the aquifer (accounting for transit time during pumping from the well screen to land surface) is estimated at 88.0 minutes. The time required to recover the center of the tracer mass that was transported within the aquifer was used in Equations (3.8) and (3.9) to calculate $\mathrm{n}_{\mathrm{e}}$ and $\mathrm{v}_{\mathrm{a}}$. As indicated in the equations, information pertaining to $\mathrm{K}, \mathrm{I}, \mathrm{b}$, and $\mathrm{Q}$ must also be known for the test well site.

As for the first test, a $\mathrm{K}$ value of $5.24 \mathrm{~m} / \mathrm{d}$ was used, which is based on results from the constant-rate pumping test for the test well (i.e., during tracer pumpback). The calculated local I value of $0.00206 \mathrm{~m} / \mathrm{m}$ and flow direction of 1 degrees ( 0 degrees East; 90 degrees North) were determined using trend-surface analysis for water-level elevation measurements from well 299-W22-50 and three nearby monitor wells (299-W22-49, 299-W23-14, and 299-W23-15) immediately prior to initiation of tracer pumpback (i.e., on May 31, 2000). The I value is nearly identical to that calculated and used for the first test, which was based on well water-level elevation measurements obtained on May 17, 2000. The I value is also consistent with that listed in Table A.2 of Hartman et al. (2000) $(0.0016 \mathrm{~m} / \mathrm{m}$ for Waste Management Area S-SX). The b value of 73.5 as calculated directly from known geologic relationships at the well site.

Based on these input parameters and tracer-pumpback results, $\mathrm{n}_{\mathrm{e}}$ and $\mathrm{v}_{\mathrm{a}}$ are estimated to be 0.272 and $0.040 \mathrm{~m} / \mathrm{d}$, respectively (Figure 6.5). Based on the observed tracer-pumpback profile and calculated radial distance traveled within the aquifer by the tracer's center of mass (i.e., product of $v_{a}$ and $t_{d}=$ $0.20 \mathrm{~m}$ ), the results of the tracer pumpback reflect local, near-well, aquifer conditions and may be susceptible to the adverse wellbore effects discussed in Section 3.2.2.

As stated previously in Section 5.4, it is not known whether the small differences in the observed tracer pumpback results for the two tests can be ascribed to changes in actual test site conditions (e.g., hydraulic gradient) or due to insensitivities of the test method. Unfortunately, it was not possible to calculate the hydraulic gradient during the first tracer test, due to the inaccessibility of one of the four wells used in the trend-surface analysis. Because of the longer tracer drift time and calculation of hydraulic gradient conditions at the time of tracer testing, hydraulic properties calculated from the second tracer test are believed more representative of actual aquifer conditions.

Table 6.1 summarizes the pertinent information associated with the tracer-pumpback tests for well 299-W22-50. The hydraulic property estimates obtained for the tracer-pumpback results generally fall 


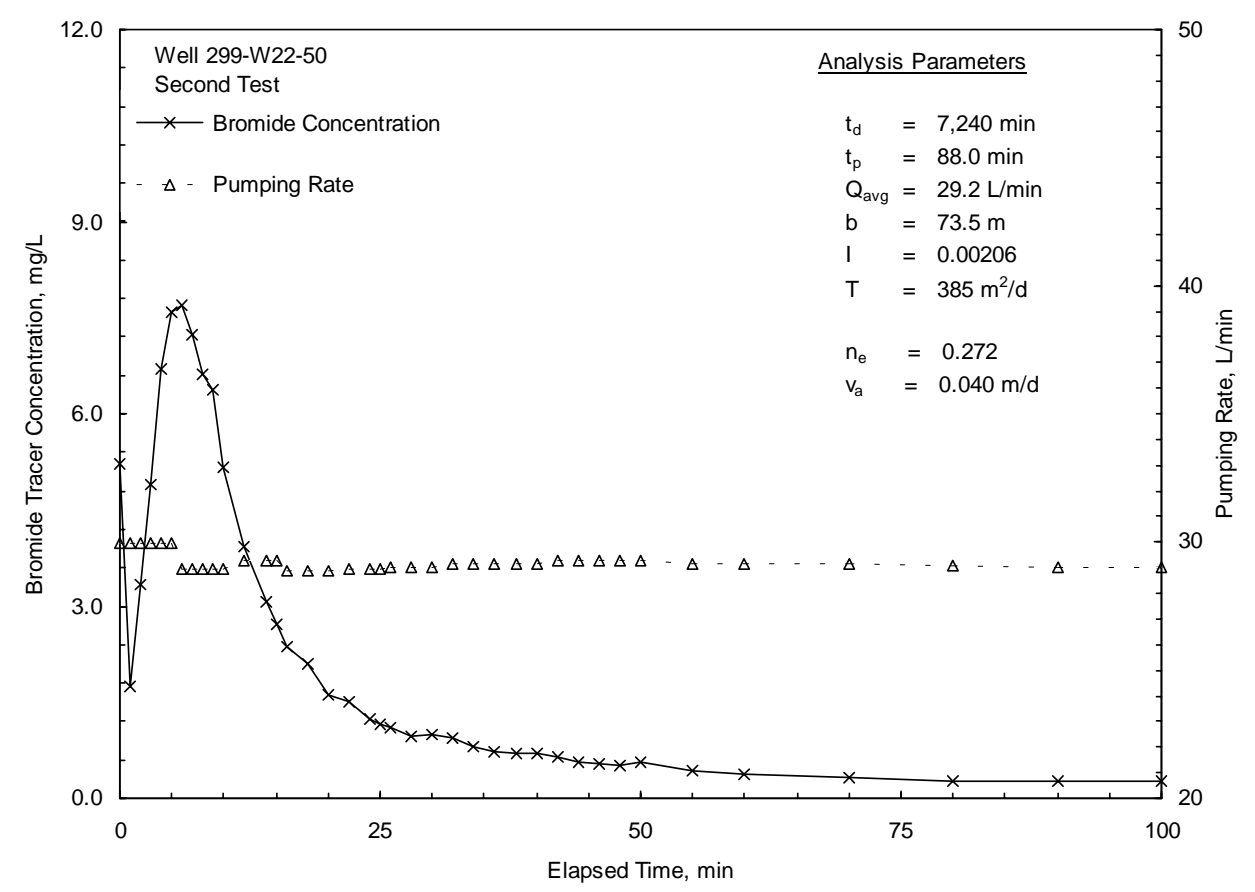

Figure 6.5. Tracer-Pumpback Test Results for Second Test, Well 299-W22-50

within the reported range $\left(\mathrm{n}_{\mathrm{e}}=0.1\right.$ to $0.3 ; \mathrm{v}_{\mathrm{a}}=0.0023$ to $\left.0.43 \mathrm{~m} / \mathrm{d}\right)$ for these parameters in Table A.2 of Hartman et al. (2000) for Waste Management Area S-SX. As noted previously, the property ranges listed by Hartman et al. (2000) are not based on direct field test results and are either assumed values (i.e., for $\mathrm{n}_{\mathrm{e}}$ ) or calculated, based on the Darcy groundwater-flow equation relationship (i.e., to estimate $\mathrm{v}_{\mathrm{a}}$ ).

\subsection{Well 699-43-44}

After a 4,045-minute (2.81-day) $t_{d}$, recovery of the tracer from well 699-43-44 and the surrounding aquifer was initiated with a constant-rate pumping test beginning on April 7, 2000 (1020 Pacific daylight time). Tracer recovery was terminated after 151 minutes. The average tracer concentration within the well was $0.75 \mathrm{mg} / \mathrm{L}$ at the beginning of pumpback. Because of the low in-well concentration, approximately $8.0 \mathrm{~g}$ of the $8.1 \mathrm{~g}$ of tracer initially emplaced in the well are estimated to have been transported within the aquifer. After minor flow adjustments were completed during the first 2 minutes of the test, pumping rates remained relatively constant during tracer pumpback, ranging between 12.86 and $15.13 \mathrm{~L} / \mathrm{min}$ (average $14.46 \mathrm{~L} / \mathrm{min}$ ) for the entire test. An estimated $2.95 \mathrm{~g}$ of the total $8.07 \mathrm{~g}$ of tracer (i.e., 37\%) emplaced in the well were recovered during the constant-rate pumping test. Because $50 \%$ of the tracer emplaced within the aquifer was not recovered during the course of the tracer pumpback phase, the estimated time required to recover the center of the tracer mass (i.e., $t_{p}$ ) could not be calculated. Because of this, no estimates for $n_{e}$ or $v_{a}$ were possible from the tracer pumpback results for this well site. The significant upward vertical flow conditions observed during the tracer-dilution phase may have contributed to the lack of sufficient tracer recovery during the course of the tracer pumpback. Tracer pumpback results for this test are shown in Figure 6.6. 


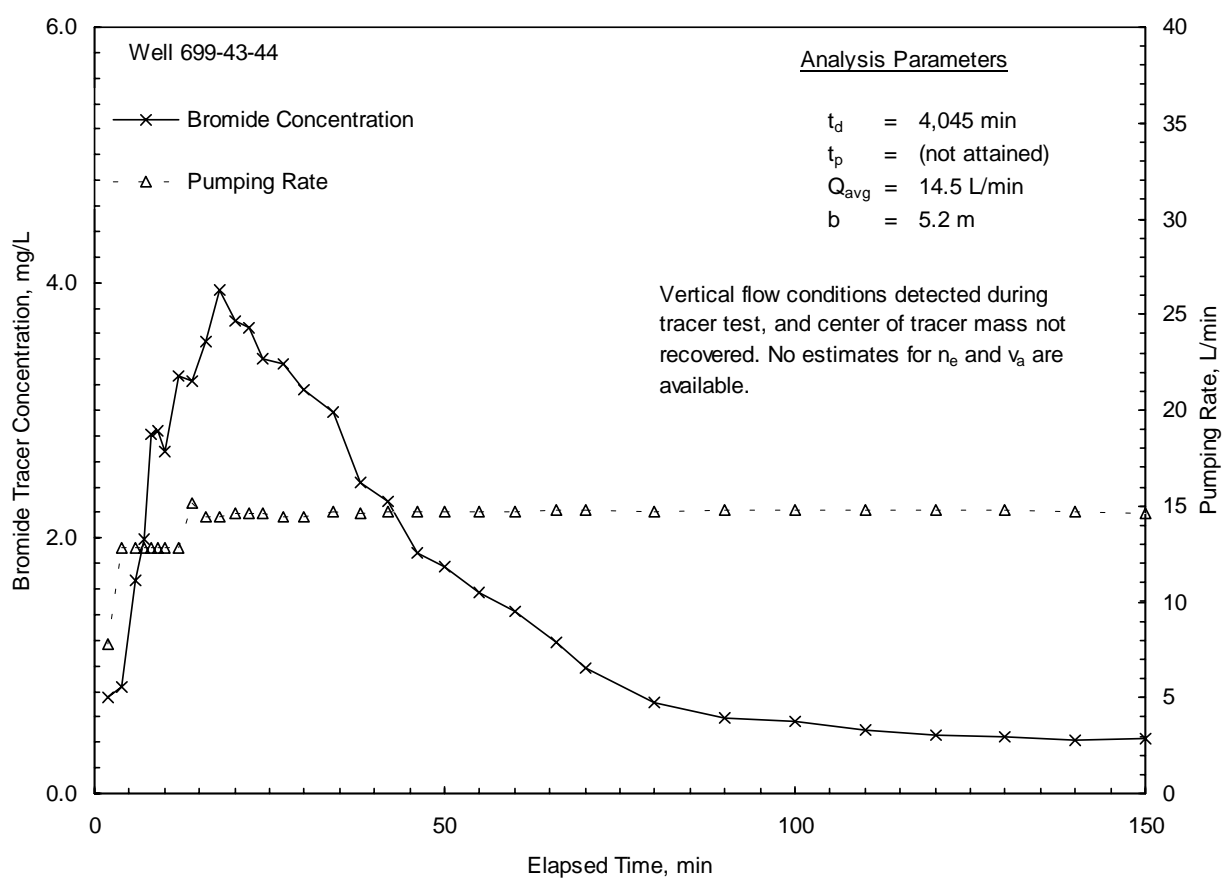

Figure 6.6. Tracer-Pumpback Test Results for Second Test, Well 699-43-44 


\subsection{Constant-Rate Pumping Test Results}

At each of the five well sites selected for detailed hydrologic characterization, pumping for the tracerpumpback test was extended and analyzed as a constant-rate pumping test. Analysis of the resulting drawdown and recovery test data at the pumped well and, for one of the sites, at a neighboring observation well provided large-scale hydraulic property estimates (i.e., transmissivity, T; hydraulic conductivity, $\mathrm{K}$; vertical anisotropy, $\mathrm{K}_{\mathrm{D}}$; storativity, $\mathrm{S}$; and specific yield, $\mathrm{S}_{\mathrm{y}}$ ). Barometric responses at each well were monitored over a baseline period and analyzed to assess and remove the effects of barometric pressure fluctuations from well water-level responses recorded during the constant-rate pumping test. Diagnostic analysis using derivative techniques (see Section 3.3.3) was applied to identify aquifer conditions and select the appropriate analysis method. Combined type-curve and derivative plot analysis was then used to determine hydraulic properties. A more detailed description of the various components of the constantrate pumping-test analysis is provided in Section 3.3. Descriptions of the performance and analysis of the constant-rate pumping tests are provided below and a summary of results is presented in Table 7.1. K estimates were calculated by dividing $\mathrm{T}$ by the total aquifer thickness, $\mathrm{b}$, rather than the length of the well-screen section at the pumping well. This is appropriate because the analysis type curves account for partial penetration of the aquifer and $\mathrm{K}_{\mathrm{D}}$.

\subsection{Well 299-W15-41}

Well 299-W15-41 penetrates the upper $4.8 \mathrm{~m}$ of the unconfined aquifer. No observation wells were located near enough to this new well to be affected by the aquifer test. The aquifer thickness at the test site is estimated at $57.6 \mathrm{~m}$. The constant-rate discharge test was conducted from 920 to 1150 Pacific standard time on May 10, 2000. Average flow rate during the test was $60.4 \mathrm{~L} / \mathrm{min}$ over the 150-minute pumping period.

Table 7.1. Constant-Rate Pumping Test Summary

\begin{tabular}{||l|l|c|c|c|c|c||}
\hline \multirow{2}{*}{$\begin{array}{c}\text { Pumping } \\
\text { Well }\end{array}$} & Well Analyzed & $\begin{array}{c}\text { Transmissivity, } \\
\mathrm{T}, \mathrm{m}^{2} / \mathrm{d}\end{array}$ & $\begin{array}{c}\text { Horizontal } \\
\text { Hydraulic } \\
\text { Conductivity, } \\
\mathrm{K}_{\mathrm{h}}, \mathrm{m} / \mathrm{d}\end{array}$ & $\begin{array}{c}\text { Vertical } \\
\text { Anisotropy, } \\
\mathrm{K}_{\mathrm{D}}\end{array}$ & $\begin{array}{c}\text { Storativity, } \\
\mathrm{S}\end{array}$ & $\begin{array}{c}\text { Specific } \\
\text { Yield, } \\
\mathrm{S}_{\mathrm{y}}\end{array}$ \\
\hline \hline 299-W15-41 & $299-W 15-41$ & 1130 & 19.6 & 0.1 & 0.00012 & 0.12 \\
\hline $299-W 22-48$ & $299-W 22-48$ & 125 & 1.78 & 0.1 & 0.00009 & 0.09 \\
\hline \multirow{3}{*}{$299-W 22-49$} & $299-W 22-49$ & 780 & 10.8 & 0.1 & 0.00012 & 0.12 \\
\cline { 2 - 8 } & $299-W 22-39^{(\mathrm{a})}$ & 550 & 7.58 & 0.1 & 0.0009 & 0.09 \\
\cline { 2 - 8 } & Best estimate & $550^{(\mathrm{a})}$ & $7.58^{(\mathrm{a})}$ & 0.1 & $0.0009^{(\mathrm{a})}$ & $0.09^{(\mathrm{a})}$ \\
\hline 299-W22-50 & $299-W 22-50$ & 385 & 5.24 & 0.1 & 0.0011 & 0.11 \\
\hline $699-43-44$ & $699-43-44$ & 8.85 & 1.70 & 0.5 & 0.00016 & 0.16 \\
\hline (a) Observation well. & \multicolumn{7}{|l|}{} \\
\hline
\end{tabular}


Barometric response characteristics were monitored for an $\sim 11$-day period at the test well. The multiple-regression deconvolution technique (Rasmussen and Crawford 1997; Spane 1999) was used to remove barometric pressure effects from the measured water levels. A total lag time of 27 hours provided the best match of barometric response for the well.

Figure 7.1 shows a diagnostic log-log plot of the barometric corrected drawdown and recovery data for pumping well 299-W15-41, and a type-curve match of the recovery data and derivative. The effect of pumping rate variations can be seen in the drawdown data before about $9 \mathrm{~min}$ of pumping. The drawdown derivative is drastically affected by these variations and was, therefore, not plotted. The declining and then increasing derivative pattern exhibited in Figure 7.1 results from the combination of partial wellpenetration and unconfined aquifer effects. It indicates that there is no portion of the data where infiniteacting, radial flow conditions are established. Therefore, straight-line analysis techniques cannot be used to analyze the test data.

The type-curve fit shown in Figure 7.1 provided the following results: $\mathrm{T}=1130 \mathrm{~m}^{2} / \mathrm{d}, \mathrm{S}=1.2 \mathrm{E}-04$, and $S_{y}=0.12$. (Note: $S$ is assumed, based on the calculated value for $S_{y}$ and a fixed $\sigma$ value of 0.001.) The K value of $19.6 \mathrm{~m} / \mathrm{d}$ was calculated by dividing $\mathrm{T}$ by the total aquifer thickness, b, because partial penetration is accounted for in the analysis. The type-curve displayed is based on a vertical anisotropy $\left(\mathrm{K}_{\mathrm{D}}\right)$ of 0.1 . This value provided slightly better fits to the data than values of 1.0 and 0.01 , though the differences in fit were relatively minor. Choosing a different value of $K_{D}$ affects the calculated $T$ with values ranging from about $900 \mathrm{~m}^{2} / \mathrm{d}$ for a $K_{D}$ of 1.0 to $1300 \mathrm{~m}^{2} / \mathrm{d}$ for a $K_{D}$ of 0.01 . As discussed in Section 3.3, the type curve also accounts for partial penetration of the aquifer thickness and well-bore storage. Values of T and K for well 299-W15-41 may be higher than calculated if significant head losses occurred at the pumping rates used in this test.

\subsection{Well 299-W22-48}

Well 299-W22-48 penetrates the upper $3.8 \mathrm{~m}$ of the unconfined aquifer. No observation wells were located near enough to this new well to be affected by the aquifer test. The aquifer thickness at the test site is estimated at $70.1 \mathrm{~m}$. The constant-rate discharge test was conducted from 920 to 1300 Pacific standard time on May 22, 2000. Average flow rate during the test was $6.96 \mathrm{~L} / \mathrm{min}$ over the 220 -minute pumping period.

Barometric response characteristics were monitored for a $\sim 13$-day period at the test well. The multiple-regression deconvolution technique (Rasmussen and Crawford 1997; Spane 1999) was used to remove barometric pressure effects from the measured water levels. A total lag time of 38 hours provided the best match of barometric response for the well.

Figure 7.2 shows a diagnostic log-log plot of the barometric corrected drawdown and recovery data for pumping well 299-W22-48, and a type-curve match of the recovery data and derivative. The effect of a slightly lower pumping rate during the first few minutes of the test is apparent in the drawdown data. Slight variations in the pumping rate also cause a large amount of noise in the derivative of the drawdown 


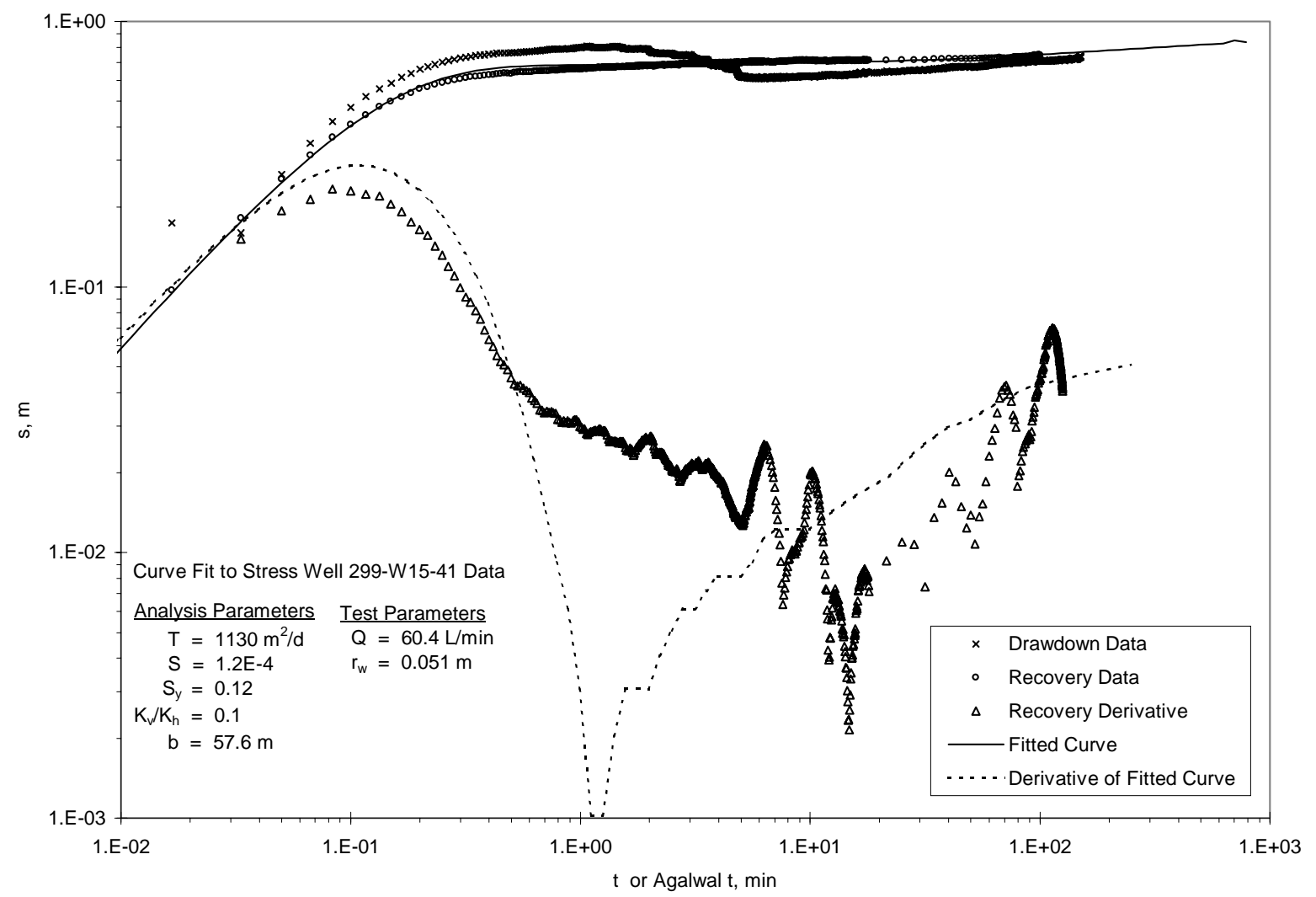

Figure 7.1. Type-Curve and Derivative Plot Analysis of Drawdown and Recovery Test Data for Pumping Well 299-W15-41

data, which was not plotted. The declining and then increasing derivative pattern exhibited in Figure 7.2 results from the combination of partial well-penetration and unconfined aquifer effects. It indicates that there is no portion of the data where infinite-acting radial flow conditions are established. Therefore, straight-line analysis techniques cannot be used to analyze the test data.

The type-curve fit shown in Figure 7.2 provided the following results: $\mathrm{T}=125 \mathrm{~m}^{2} / \mathrm{d}, \mathrm{S}=9.0 \mathrm{E}-05$, and $S_{y}=0.09$. (Note: $S$ is assumed, based on the calculated value for $S_{y}$ and a fixed $\sigma$ value of 0.001.) The $\mathrm{K}$ value of $1.78 \mathrm{~m} / \mathrm{d}$ was calculated by dividing $\mathrm{T}$ by the total aquifer thickness, $\mathrm{b}$, because partial penetration is accounted for in the analysis. The type-curve displayed is based on a vertical anisotropy $\left(K_{D}\right)$ of 0.1 . This value provided slightly better fits to the data than values of 1.0 and 0.01 , although the differences in fit were relatively minor. Choosing a different value of $\mathrm{K}_{\mathrm{D}}$ affects the calculated $\mathrm{T}$ so that lower $\mathrm{T}$ values are calculated for $\mathrm{a} \mathrm{K}_{\mathrm{D}}$ between 0.1 and 1.0, and higher $\mathrm{T}$ values are calculated for a $\mathrm{K}_{\mathrm{D}}$ of less than 0.1. As discussed in Section 3.3, the type curve also accounts for partial penetration of the aquifer thickness and well-bore storage. Values of T and K for well 299-W22-48 may be higher than calculated if significant head losses occurred at the pumping rates used in this test. However, because the pumping rates were relatively low and other new RCRA wells installed in the 200 West Area with the 


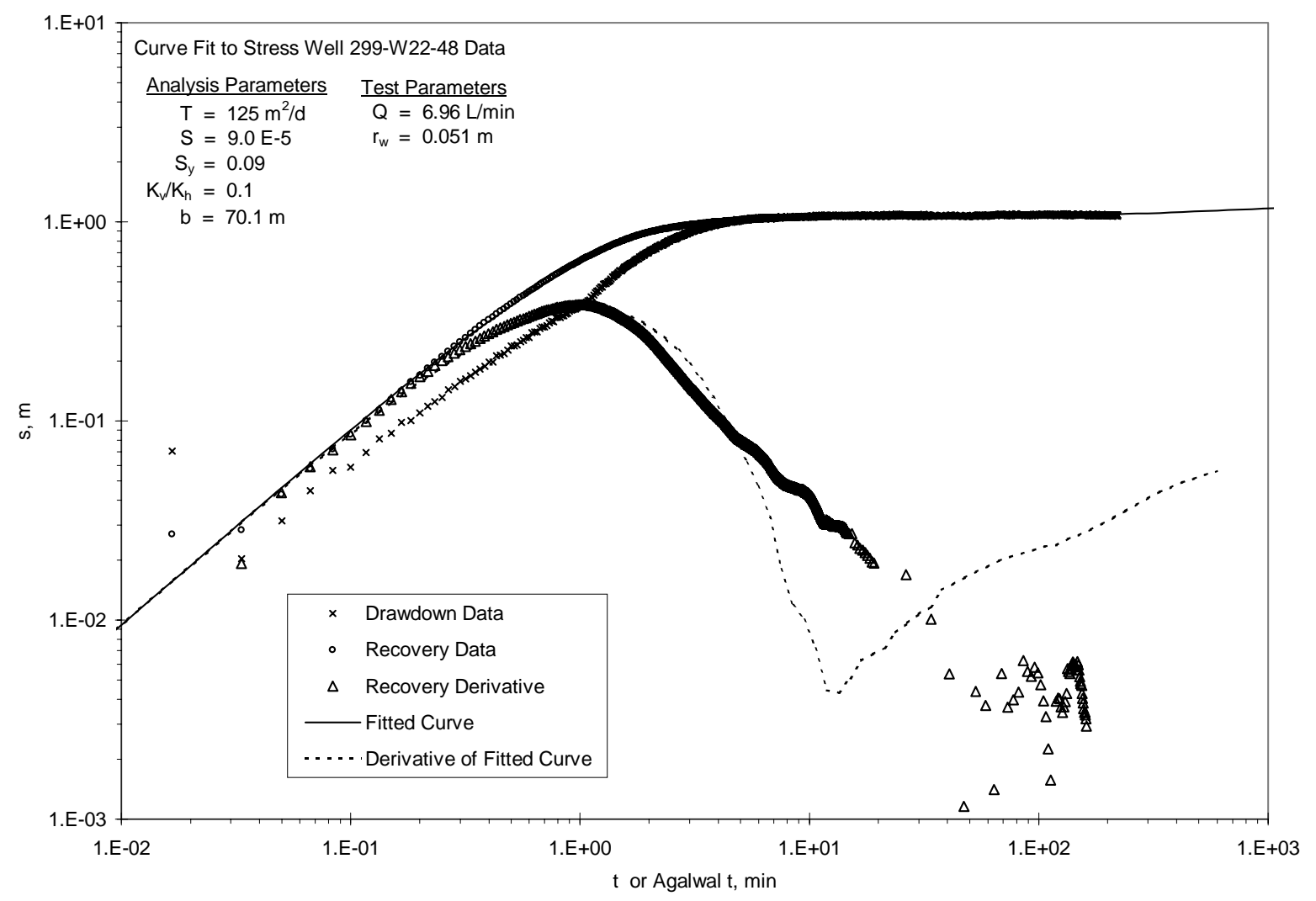

Figure 7.2. Type-Curve and Derivative Plot Analysis of Drawdown and Recovery Test Data for Pumping Well 299-W22-48

same design have shown very little head loss at the well (Spane et al. 2001), results of the type-curvefitting analysis for pumping well 299-W22-48 are considered to provide representative estimates of aquifer hydraulic properties.

\subsection{Well 299-W22-49}

Well 299-W22-49 penetrates the upper $4.5 \mathrm{~m}$ of the unconfined aquifer. An observation well, 299-W22-39, is located at a radial distance of $12.1 \mathrm{~m}$ from well 299-W22-49 and penetrates $3.9 \mathrm{~m}$ below the water table. The aquifer thickness at the test site is estimated at $72.5 \mathrm{~m}$. The constant-rate discharge test was conducted from 0915 to 1230 Pacific standard time on April 20, 2000. The average flow rate was $42.2 \mathrm{~L} / \mathrm{min}$ over the 195 -min pumping period.

Barometric response characteristics were monitored for $\sim 9$ days at both the pumping and observation wells (299-W22-49 and 299-W22-39). The multiple-regression deconvolution technique (Rasmussen and Crawford 1997; Spane 1999) was used to remove barometric pressure effects from the measured water levels. A total lag time of 46 hours provided the best match of barometric responses for both well sites. 
Figure 7.3 shows the diagnostic log-log plot and type-curve match of the barometric corrected recovery data and derivative for pumping well 299-W22-49. Drawdown data and derivative are also shown in the plot, but were not used for matching because of the detrimental effects of small variations in discharge rate during the test. The declining derivative pattern exhibited in Figure 7.3 (as a result of partial penetration effects) indicates there is no portion of the data where infinite-acting, radial flow conditions are established. Therefore, straight-line analysis techniques cannot be used to analyze the test data.

The type-curve fit shown in Figure 7.3 provided the following results: $\mathrm{T}=780 \mathrm{~m}^{2} / \mathrm{d}, \mathrm{S}=1.2 \mathrm{E}-04$, and $S_{y}=0.12$. (Note: $S$ is assumed, based on the calculated value for $S_{y}$ and a fixed $\sigma$ value of 0.001.) The type-curve displayed is based on a vertical anisotropy $\left(\mathrm{K}_{\mathrm{D}}\right)$ of 0.1 . This $\mathrm{K}_{\mathrm{D}}$ value provided a much better fit to the data than when a $K_{D}$ of 1.0 was used and a slightly better fit than when a value of 0.01 was used. Choosing a different value of $K_{D}$ affects the calculated $T$ with values ranging from about $700 \mathrm{~m}^{2} / \mathrm{d}$ for a $K_{D}$ of 1.0 to $900 \mathrm{~m}^{2} / \mathrm{d}$ for a $K_{D}$ of 0.01 . As discussed in Section 3.3, the type curve also accounts for well partial penetration of the aquifer thickness and wellbore storage. The pumping well did not display

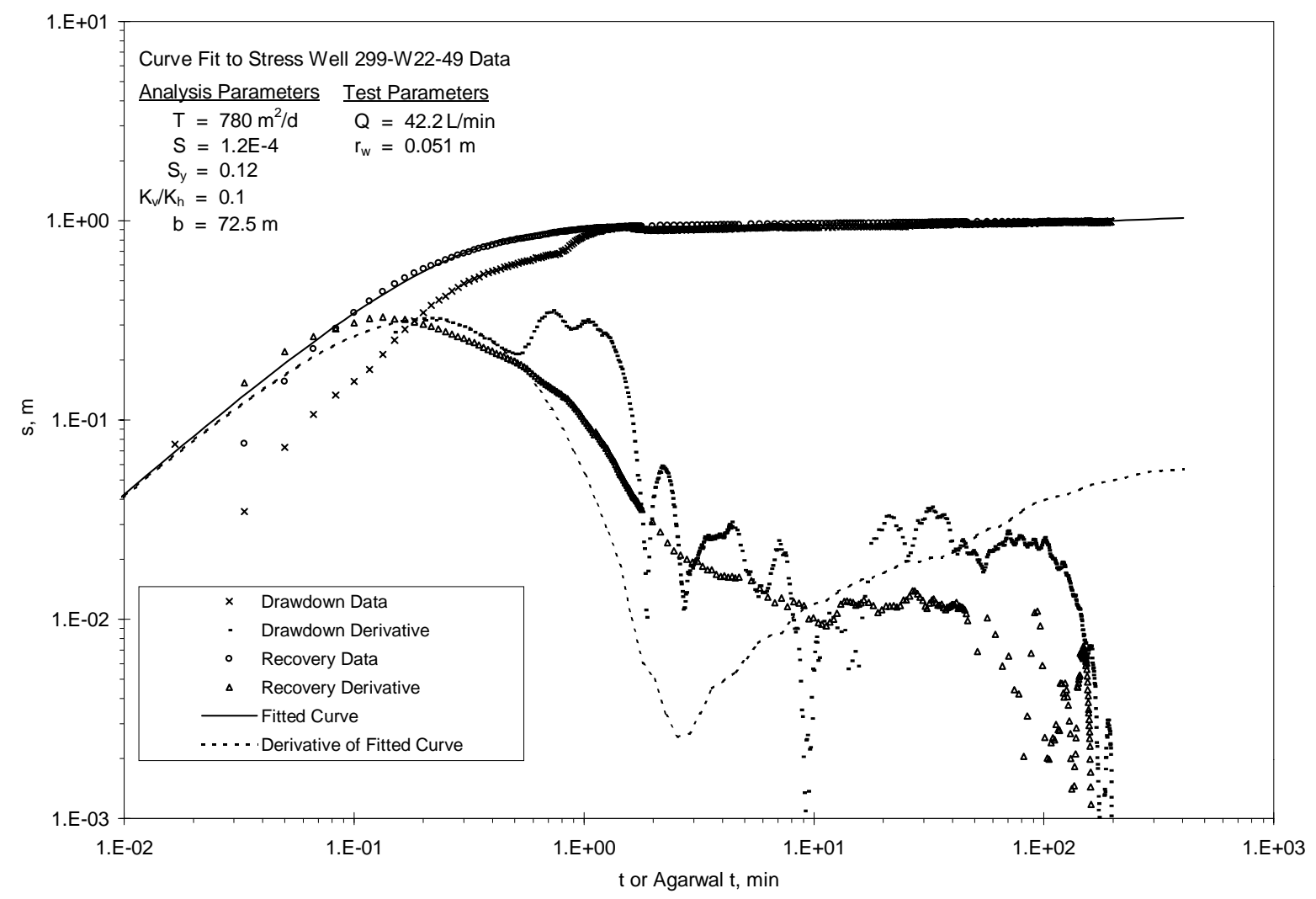

Figure 7.3. Type-Curve and Derivative Plot Analysis of Drawdown and Recovery Test Data for Pumping Well 299-W22-49 
significant head losses at the pumping rates used in these tests. This is apparent because type-curve fitting of the observation well data yielded values for $\mathrm{T}$ that were lower than the pumping well results. Head losses at the pumping well would result in calculated $\mathrm{T}$ being lower than the actual aquifer $\mathrm{T}$. Therefore, results of the type-curve-fitting analysis for pumping well 299-W22-49 are considered to provide representative estimates of aquifer hydraulic properties in the vicinity of the pumping well.

Drawdown and recovery data for observation well 299-W22-39 are shown in Figure 7.4, along with the derivative of the recovery data. The difference in drawdown and recovery response may be explained by the lower discharge rate during the first few minutes of pumping. It also appears that some residual barometric fluctuations may have affected the drawdown data. Note that the total drawdown at the observation well was less than $0.08 \mathrm{~m}$.

The type-curve fit to the observation well recovery data produced the following analysis results: $\mathrm{T}=550 \mathrm{~m}^{2} / \mathrm{d}, \mathrm{S}=9.0 \mathrm{E}-04$, and $\mathrm{S}_{\mathrm{y}}=0.09$. $\mathrm{S}$ was based on the calculated value for $\mathrm{S}_{\mathrm{y}}$ and a $\sigma$ value of 0.01 . This $\sigma$ value provided a better match than the value of 0.001 assumed for the pumping well analysis. The $\mathrm{T}$ value from type-curve matching of the observation well recovery data is somewhat less than the value of $780 \mathrm{~m}^{2} / \mathrm{d}$ calculated from the pumping well analysis. Moving the type curve downward to

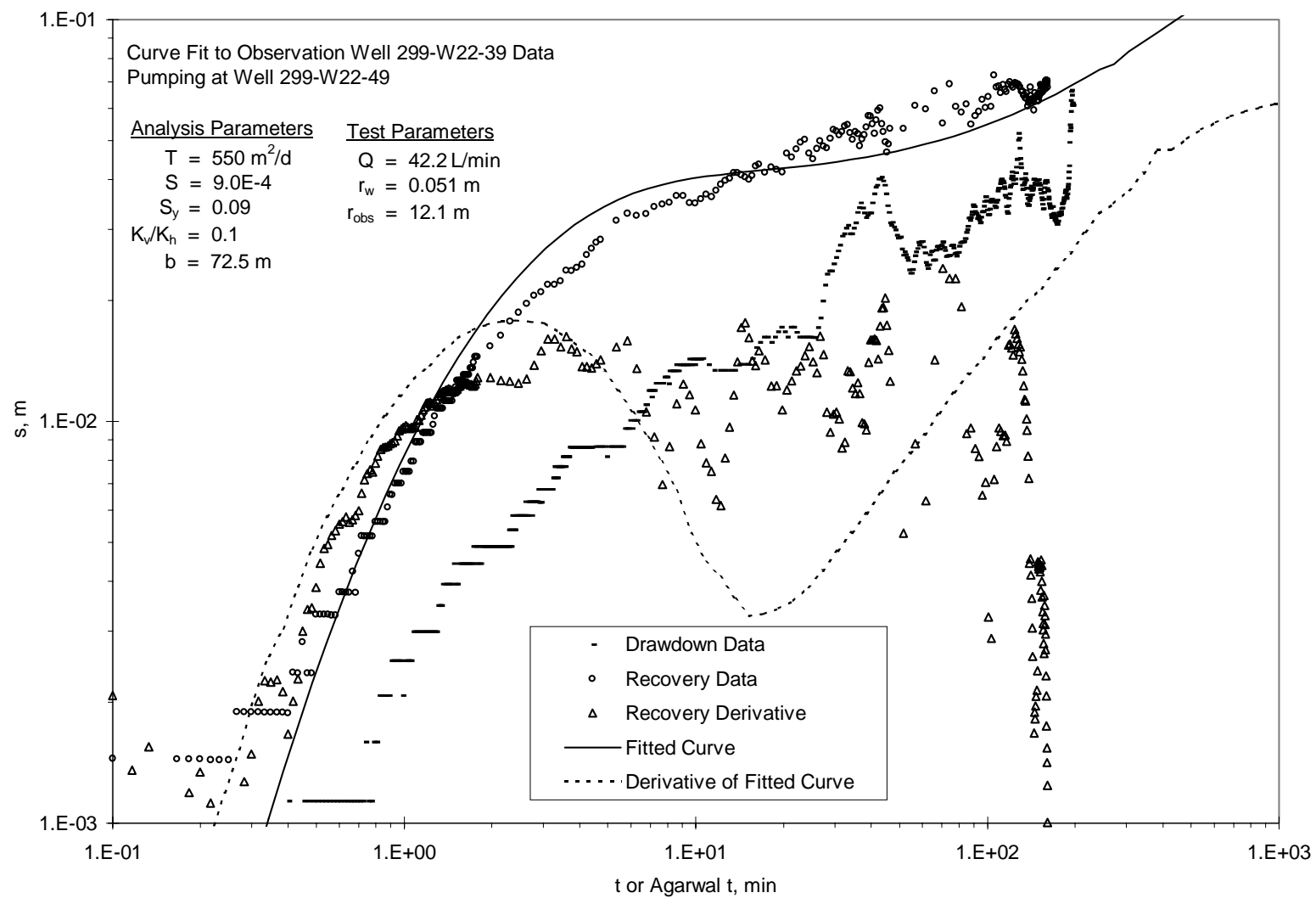

Figure 7.4. Type-Curve and Derivative Plot Analysis of Drawdown and Recovery Test Data for Observation Well 299-W22-39 
better match the drawdown data at the observation well increases the calculated $\mathrm{T}$, so that it is similar to the pumping well result. However, the observation well recovery data provides a better match of the curve shape and lateral position, which influence the calculated values of $S$ and $S_{y}$. Observation well data generally provide the best estimates of $S$ and $S_{y}$ because there are less effects from wellbore storage and friction loss than at the pumping well. Therefore, the values from the observation well analysis were selected as the best estimates of hydraulic properties for this test site. The lower values of $\mathrm{T}$ and $\mathrm{K}$ from the observation well analysis could be caused by aquifer heterogeneity.

Figure 7.5 shows a composite analysis of data from both the pumping well and the observation well. The $\mathrm{x}$-axis represents $\mathrm{t} / \mathrm{r}^{2}$ to normalize the plot for the radial distance, $\mathrm{r}$. The predicted test responses shown for the pumping and observations wells are based on analysis results obtained from the observation well, 299-W22-39. The relatively poor match to the pumping well data is expected given the differences in calculated $\mathrm{T}$ values obtained for the individual pumping and observation well analyses. Best estimates of hydraulic properties for the test site, based on the observation well analysis, are $\mathrm{T}=550 \mathrm{~m}^{2} / \mathrm{d}, \mathrm{S}=$ $9.0 \mathrm{E}-04, \mathrm{~S}_{\mathrm{y}}=0.09$, and $\mathrm{K}=7.59 \mathrm{~m} / \mathrm{d}$. The $\mathrm{K}$ value of $7.58 \mathrm{~m} / \mathrm{d}$ was calculated by dividing $\mathrm{T}$ by the total aquifer thickness, $\mathrm{b}$, because partial penetration is accounted for in the analysis.

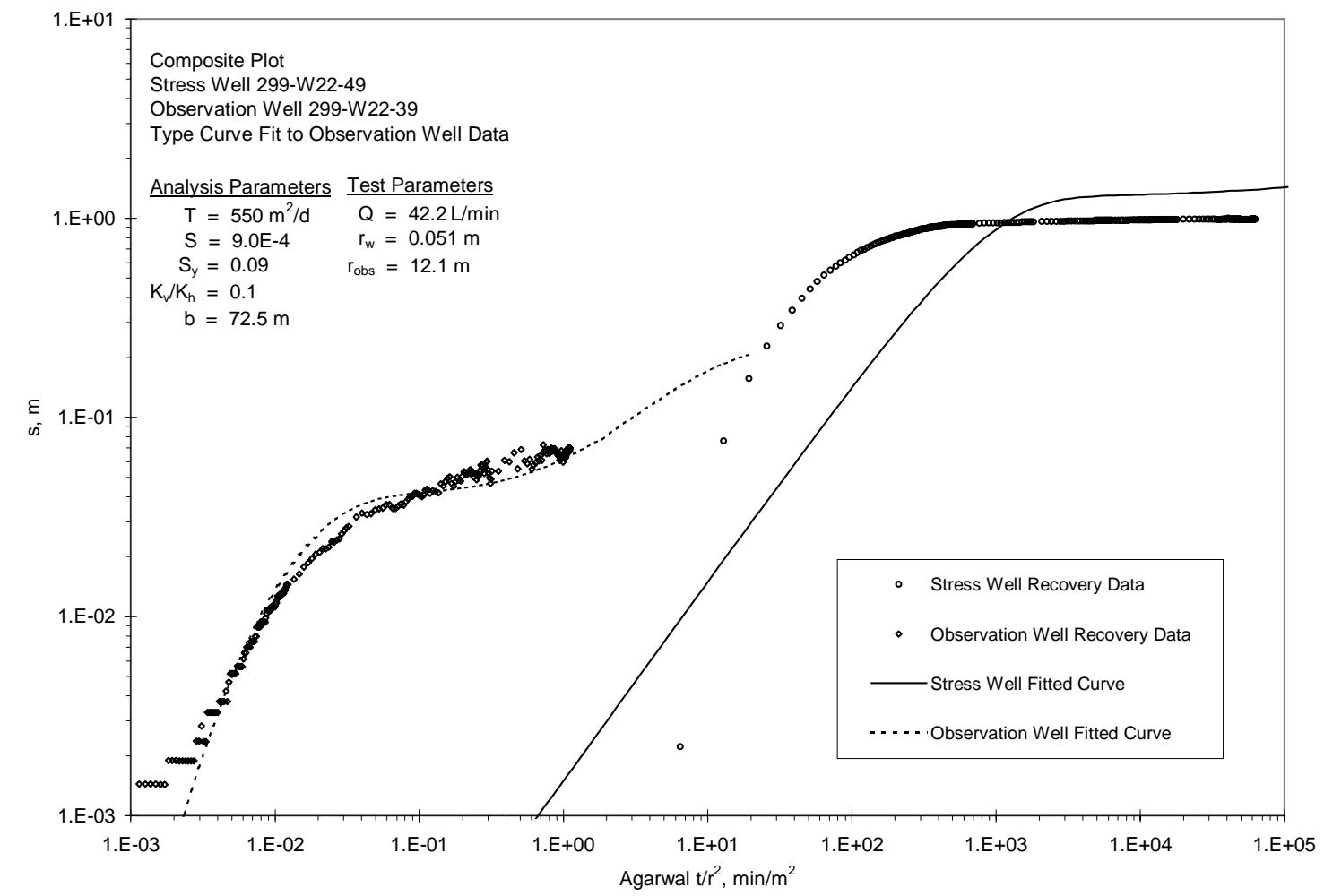

Figure 7.5. Composite Type-Curve and Derivative Plot Analysis for Pumping Well 299-W22-49 and Observation Well 299-W22-39 


\subsection{Well 299-W22-50}

Well 299-W22-50 penetrates the upper $4.3 \mathrm{~m}$ of the unconfined aquifer. No observation wells were located near enough to this new well to be affected by the aquifer test. The aquifer thickness at the test site is estimated at $73.5 \mathrm{~m}$. Two constant-rate discharge tests were conducted at this site. The first test was from 910 to 1230 Pacific standard time on May 5, 2000. Average flow rate during test \#1 was $28.5 \mathrm{~L} / \mathrm{min}$ over the 200 -minute pumping period. The second constant rate test was conducted from 935 to 1136 Pacific standard time on May 31, 2000. Average flow rate during test \#2 was $29.2 \mathrm{~L} / \mathrm{min}$ over the 121-min pumping period.

Barometric response characteristics were monitored for a 13-day period at the test well. The multiple-regression deconvolution technique (Rasmussen and Crawford 1997; Spane 1999) was used to remove barometric pressure effects from the measured water levels. A total lag time of 46 hours provided the best match of barometric response for the well.

Figure 7.6 shows a log-log plot of the drawdown and recovery responses during both tests. Test \#1 was affected by flow-rate variations in the first few minutes of the test and appears to be affected by an external stress that causes decreasing drawdown during the later part of the pumping phase. This stress may also have had an impact on the tracer drift and pumpback results, which differed from those found

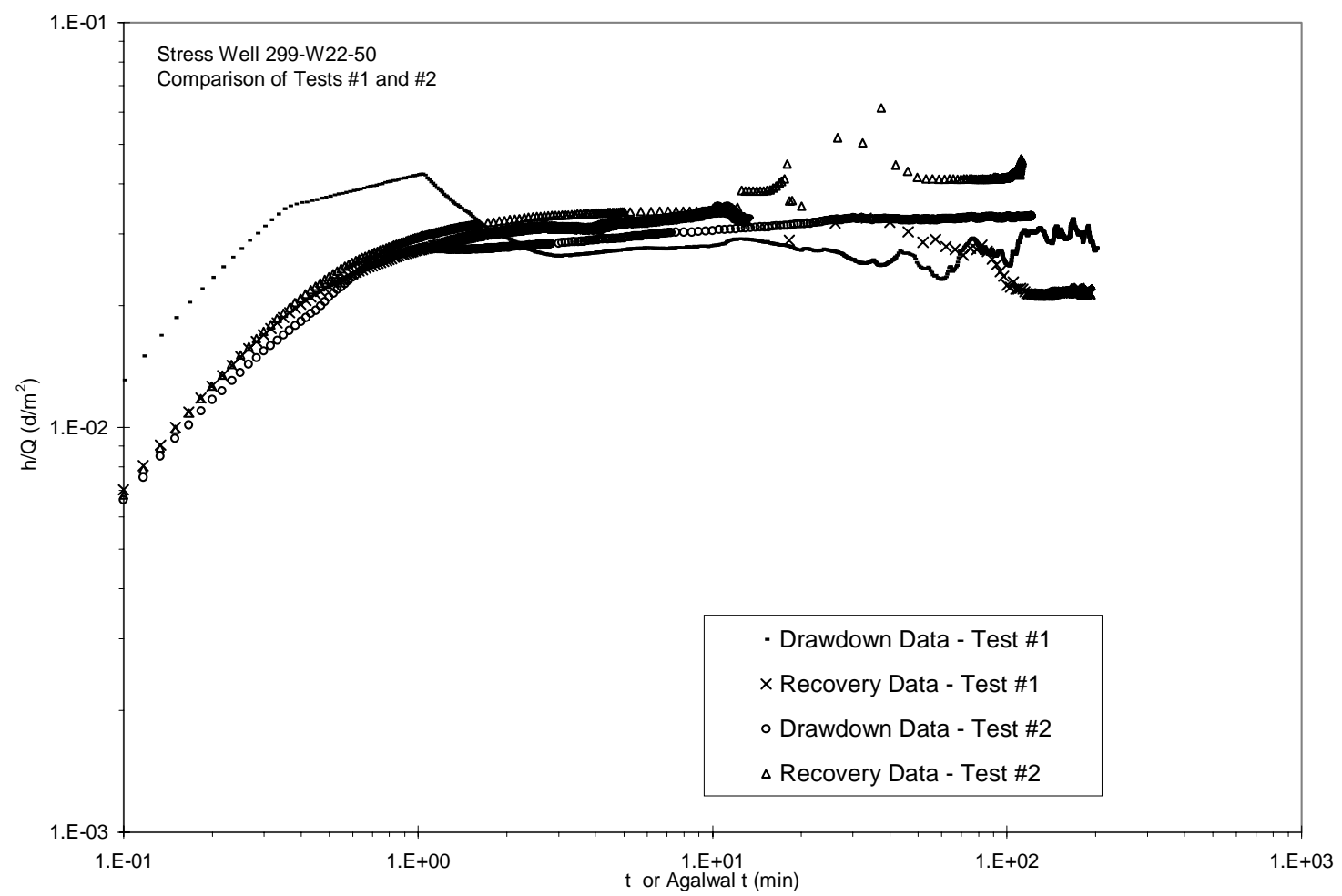

Figure 7.6. Comparison of Drawdown and Recovery Responses for Pumping Well 299-W22-50, During Test \#1 and Test \#2 
during test \#2 (see Section 5.4). Attempts to remove this external stress from the drawdown and recovery data as a simple trend were not successful. Because of the uncharacteristic responses during test \#1, the test \#2 was used for analysis. However, later time recovery data from test \#2, after about 10 minutes was affected by a pressure transducer problem. This may have been caused by water entering the vent tube of the pressure probe.

Figure 7.7 shows a diagnostic log-log plot of the barometric corrected drawdown and recovery data for pumping well 299-W22-50 during test \#2. A type-curve match of the early recovery data and derivative and the later drawdown data is also shown. The recovery derivative was not plotted for the time period when measurements were affected by the transducer problem. The declining and then increasing derivative pattern of the type curve in Figure 7.7 results from the combination of partial wellpenetration and unconfined aquifer effects. It indicates that there is no portion of the data where infiniteacting radial flow conditions are established. Therefore, straight-line analysis techniques cannot be used to analyze the test data. The drawdown derivative does not match the type curve derivative pattern very well because of flow-rate variations during pumping.

The type-curve fit shown in Figure 7.7 provided the following results: $\mathrm{T}=385 \mathrm{~m}^{2} / \mathrm{d}, \mathrm{S}=1.1 \mathrm{E}-05$, and $S_{y}=0.11$. (Note: $S$ is assumed, based on the calculated value for $S_{y}$ and a fixed $\sigma$ value of 0.001 .) The $\mathrm{K}$ value of $5.24 \mathrm{~m} / \mathrm{d}$ was calculated by dividing $\mathrm{T}$ by the total aquifer thickness, b, because partial

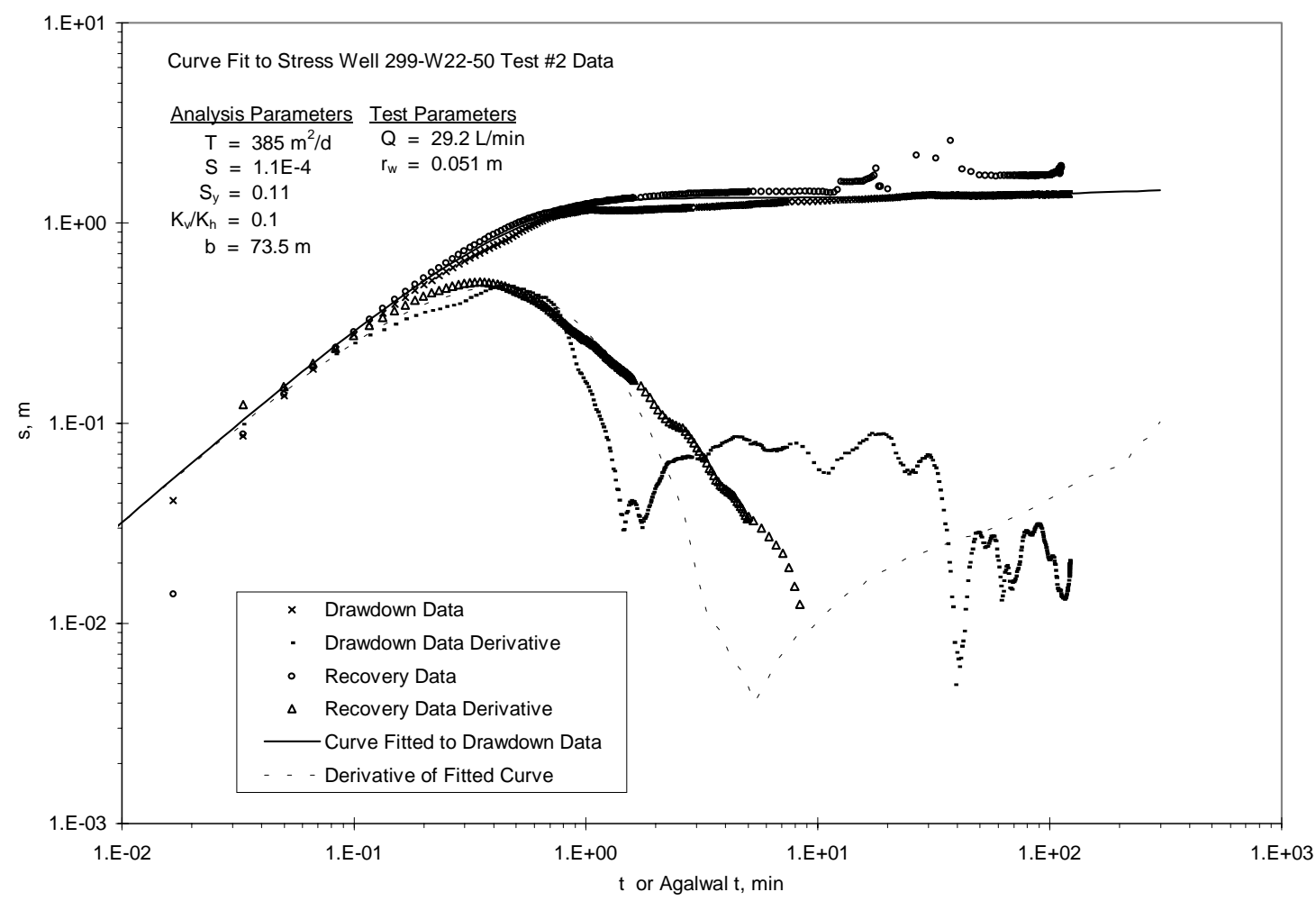

Figure 7.7. Type-Curve and Derivative Plot Analysis of Drawdown and Recovery Test Data for Pumping Well 299-W22-50, Test \#2 
penetration is accounted for in the analysis. The type-curve displayed is based on a vertical anisotropy $\left(\mathrm{K}_{\mathrm{D}}\right)$ of 0.1 . This value provided slightly better fits to the data than values of 1.0 and 0.01 , though the differences in fit were relatively minor. Choosing a different value of $\mathrm{K}_{\mathrm{D}}$ affects the calculated $\mathrm{T}$ so that lower $T$ values are calculated for a $K_{D}$ between 0.1 and 1.0, and higher $T$ values are calculated for a $K_{D}$ of less than 0.1. As discussed in Section 3.3, the type curve also accounts for partial penetration of the aquifer thickness and well-bore storage. Values of T and K for well 299-W22-50 may be higher than calculated if significant head losses occurred at the pumping rates used in this test. However, because the pumping rates were relatively low and other new RCRA wells installed in the 200 West Area with the same design have shown very little head loss at the well (Spane et al. 2001), results of the type-curvefitting analysis for pumping well 299-W22-50 are considered to provide representative estimates of aquifer hydraulic properties.

\subsection{Well 699-43-44}

Well 699-43-44 penetrates the upper $4.9 \mathrm{~m}$ of the unconfined aquifer, which is almost the entire $5.2 \mathrm{~m}$ aquifer thickness. No observation wells were located near enough to this new well to be affected by the aquifer test. The constant-rate discharge test was conducted from 850 to 1123 Pacific standard time on April 7, 2000. Average flow rate during the test was $14.5 \mathrm{~L} / \mathrm{min}$ over the 213 -min pumping period.

Barometric response characteristics were monitored for a 6-day period at the well 699-43-44. However, the barometric response was found to have an insignificant effect on the test data for the pumping well. This test site is located in a different area, with a much higher vadose zone diffusivity value than any of the other wells tested for this report.

Figure 7.8 shows a diagnostic log-log plot of the drawdown and recovery data for pumping well 699-43-44, and a type-curve match of the recovery data and derivative. The effect of flow-rate variations is apparent in the drawdown data. These variations cause a large amount of noise in the derivative of the drawdown data, which was not plotted. The declining and then increasing derivative pattern exhibited in Figure 7.8 results from the delayed-yield effect of the unconfined aquifer. It indicates that there is no portion of the data where infinite-acting radial flow conditions are established. Therefore, straight-line analysis techniques cannot be used to analyze the test data.

The type-curve fit shown in Figure 7.8 provided the following results: $\mathrm{T}=8.85 \mathrm{~m}^{2} / \mathrm{d}, \mathrm{S}=1.6 \mathrm{E}-04$, and $S_{y}=0.16$. (Note: $S$ is assumed, based on the calculated value for $S_{y}$ and a fixed $\sigma$ value of 0.001 .) The $\mathrm{K}$ value of $1.70 \mathrm{~m} / \mathrm{d}$ was calculated by dividing $\mathrm{T}$ by the total aquifer thickness, $\mathrm{b}$, because partial penetration is accounted for in the analysis. The type-curve displayed is based on a vertical anisotropy $\left(\mathrm{K}_{\mathrm{D}}\right)$ of 0.5 . Because the pumping well penetrated about $95 \%$ of the aquifer thickness at this test site, the $\mathrm{K}_{\mathrm{D}}$ had only a minor effect on the shape of the match curve; however, the $\mathrm{K}_{\mathrm{D}}$ value of 0.5 gave slightly better curve-matching results than the standard $K_{D}$ value of 0.01 used in most of the pump test analyses. As discussed in Section 3.3, the type curve also accounts for partial penetration of the aquifer thickness and well-bore storage. Values of T and $\mathrm{K}$ for well 699-43-44 may be higher than calculated if significant head losses occurred at the pumping rates used in this test. However, because the pumping rates were 


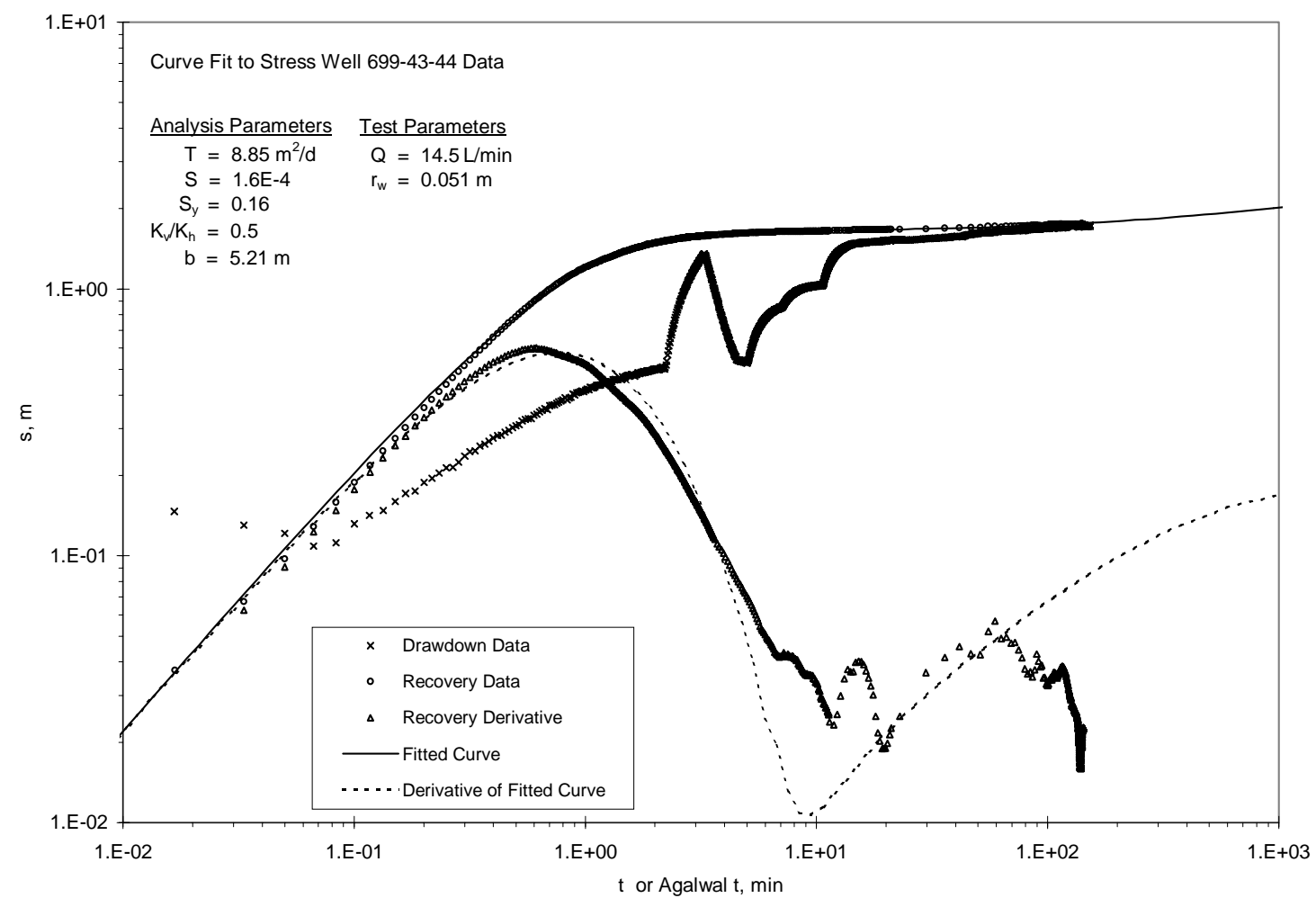

Figure 7.8. Type-Curve and Derivative Plot Analysis of Drawdown and Recovery Test Data for Pumping Well 699-43-44

relatively low and other new RCRA wells with the same design have shown very little head loss at the well (Spane et al. 2001), results of the type-curve-fitting analysis for pumping well 699-43-44 are considered to provide representative estimates of aquifer hydraulic properties. 


\subsection{In-Well, Vertical Flow Test Results}

As will be discussed in this section, the tracer concentration versus depth-response patterns exhibited during the tracer-dilution tests conducted at wells 299-W22-49 and 699-43-44 exhibited evidence of vertical flow conditions within the well-screen section. The cause of the induced vertical flow conditions is not known, but may be the result of either 1) proximity to local discharge, 2) heterogeneous formation conditions along the well screen, or 3) effects from neighboring well-pumping/-sampling or remedial action activities. The existence of vertical flow is not necessarily reflective of actual groundwater-flow conditions within the surrounding aquifer, but its presence implies a vertical flow gradient and has implications pertaining to the representativeness of groundwater samples collected from such monitor well facilities. An instructive numerical model study that examines the effects of vertical flow imposed by well-screen completions, in the presence of extremely low hydraulic gradients, is presented in Reilly et al. (1989).

To corroborate the upward vertical flow conditions calculated during the tracer-dilution tests, a follow-up, vertical, flow-tracer test was conducted at well 699-43-44 and an EM vertical flow-meter survey was conducted at both well sites. Results determined from the three methods are discussed below for each well site and are summarized in Table 8.1. As indicated in Table 8.1, consistent and comparable vertical flow estimates were obtained using all three methods. Similar consistency between methods was described in Spane et al. (2001) for two wells characterized in FY 1999, where downward, in-well vertical flow conditions were detected.

\subsection{Well 299-W22-49}

Visual examination of the tracer concentration versus depth-response patterns shown in Figure 8.1 for the tracer-dilution test conducted on April 17, 2000 (discussed in Section 5.3) indicates a, vertical,

Table 8.1. In-Well, Vertical, Flow-Velocity Calculation Summary for Wells 299-W10-26 and 299-W14-13

\begin{tabular}{|c|c|c|c|c|c|c|}
\hline \multirow[b]{2}{*}{ Test Well } & \multicolumn{2}{|c|}{ Tracer-Dilution Profile } & \multicolumn{2}{|c|}{ Vertical Tracer Test ${ }^{(a)}$} & \multicolumn{2}{|c|}{$\begin{array}{c}\text { Electromagnetic Flow-Meter } \\
\text { Survey }\end{array}$} \\
\hline & $\begin{array}{l}\text { Range, } \\
\mathrm{m} / \mathrm{min}\end{array}$ & $\begin{array}{c}\text { Average, } \\
\mathrm{m} / \mathrm{min}\end{array}$ & Range, $\mathrm{m} / \mathrm{min}$ & $\begin{array}{c}\text { Average, } \\
\mathrm{m} / \mathrm{min}\end{array}$ & $\begin{array}{c}\text { Range, } \\
\mathrm{m} / \mathrm{min}\end{array}$ & $\begin{array}{c}\text { Average, } \\
\mathrm{m} / \mathrm{min}\end{array}$ \\
\hline 299-W22-49 & $\begin{array}{c}0.010-0.015 \\
\uparrow\end{array}$ & $\begin{array}{c}0.012 \\
\uparrow\end{array}$ & NA & NA & $\begin{array}{c}0.002-0.017 \\
\uparrow\end{array}$ & $\begin{array}{c}0.010 \\
\uparrow\end{array}$ \\
\hline $699-43-44$ & $\begin{array}{c}0.008-0.015 \\
\uparrow\end{array}$ & $\begin{array}{c}0.011 \\
\uparrow\end{array}$ & $\begin{array}{c}0.006-0.008 \\
\uparrow\end{array}$ & $\begin{array}{c}0.006 \\
\uparrow\end{array}$ & $\begin{array}{c}0.001-0.014 \\
\uparrow\end{array}$ & $\begin{array}{c}0.008 \\
\uparrow\end{array}$ \\
\hline \multicolumn{7}{|c|}{ 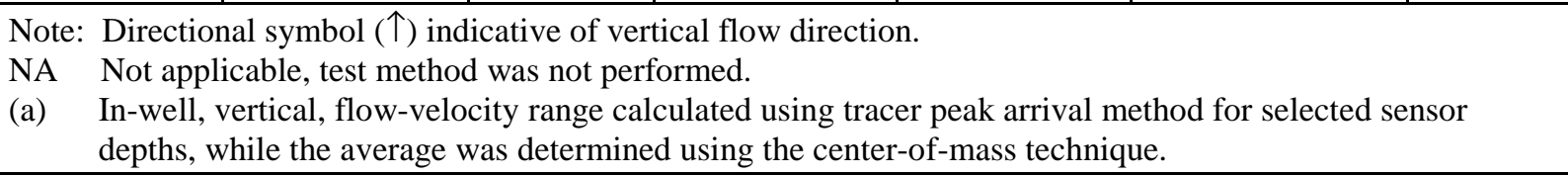 } \\
\hline
\end{tabular}




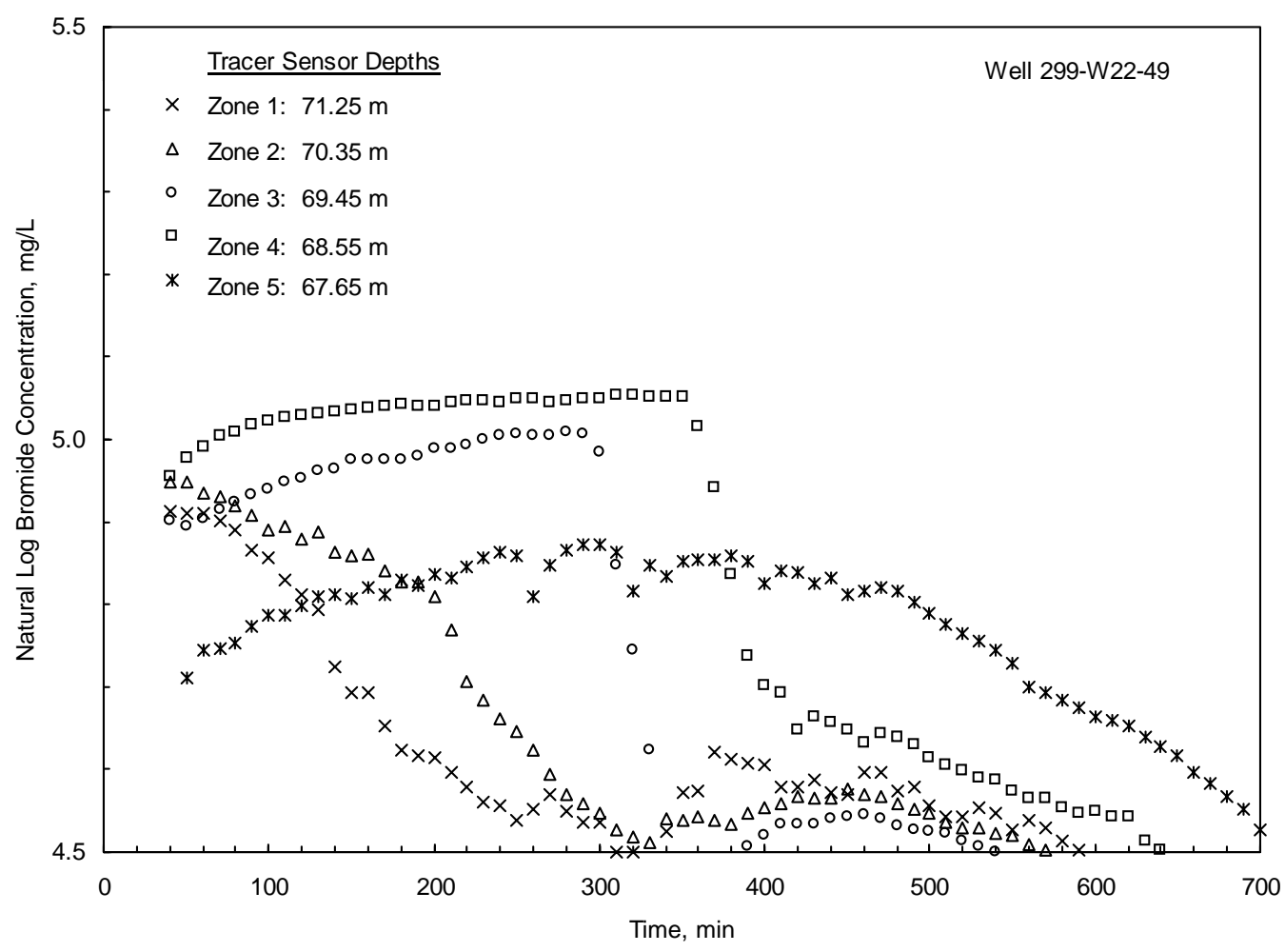

Figure 8.1. Tracer Concentration Versus Depth-Response Patterns Within Well 299-W22-49 During Tracer-Dilution Testing

upward-flow condition within the upper half of the well-screen section. Upward-flow velocities, ranging between 0.010 to $0.015 \mathrm{~m} / \mathrm{min}$, were calculated, based on arrival times of recognizable signatures between the lower four bromide probe sensors.

Because of regulatory water-sampling time constraints, a vertical flow-tracer test was not conducted at well 299-W22-49. Vertical flow measurements, however, were obtained directly within well 299-W22-49 on January 21, 2000 using an EM flow meter. Flow-meter results reported in Waldrop and Pearson (2000) over a 3-m well-screen section (i.e., at 67.4 to $70.4 \mathrm{~m}$ below top of casing) provided velocity values between 0.002 and $0.017 \mathrm{~m} / \mathrm{min}$.

Table 8.1 summarizes the calculations determined within well 299-W22-49. As indicated, comparable velocities and consistent indications of upward-flow conditions within the well-screen section were indicated for the two methods. The fact that the flow-meter survey and tracer-dilution tracer tests were conducted nearly 3 months apart, and still provided consistent results, suggests that the vertical flow condition is a persistent characteristic. 


\subsection{Well 699-43-44}

Visual examination of the tracer concentration versus depth-response patterns (shown in Figure 8.2) for the tracer-dilution test conducted on April 4, 2000 (discussed in Section 5.5) indicates a vertical, upward-flow condition within the well-screen section. Upward, in-well, flow velocities, ranging between 0.008 and $0.015 \mathrm{~m} / \mathrm{min}$, were calculated by using the arrival times of recognizable tracer signatures between the top four sensors.

To corroborate vertical flow conditions within the well-screen section, a vertical flow-tracer test was conducted on April 28, 2000 (0948 Pacific daylight time). To perform the test, an assembly of five bromide probe sensors, using a fixed separation distance of $0.9 \mathrm{~m}$, was lowered into the well. Final depth settings for the five sensors were 54.9, 55.8, 56.7, 57.6, and $58.5 \mathrm{~m}$ below top of casing, which are the same sensor depth-settings used during the tracer-dilution test. The test was initiated by introducing $2.0 \mathrm{~L}$ of tracer solution (containing $0.40 \mathrm{~g}$ of bromide) within the lower $0.75-\mathrm{m}$ well-screen section. The tracer was introduced into the well using a 0.003 -m-inner-diameter polypropylene tube that was attached to the bromide sensor assembly. The tube end was open at a depth of $57.75 \mathrm{~m}$ below top of casing. An electrically activated solenoid valve, connected to the tube at a depth of $52.5 \mathrm{~m}$ below top of casing, was used to

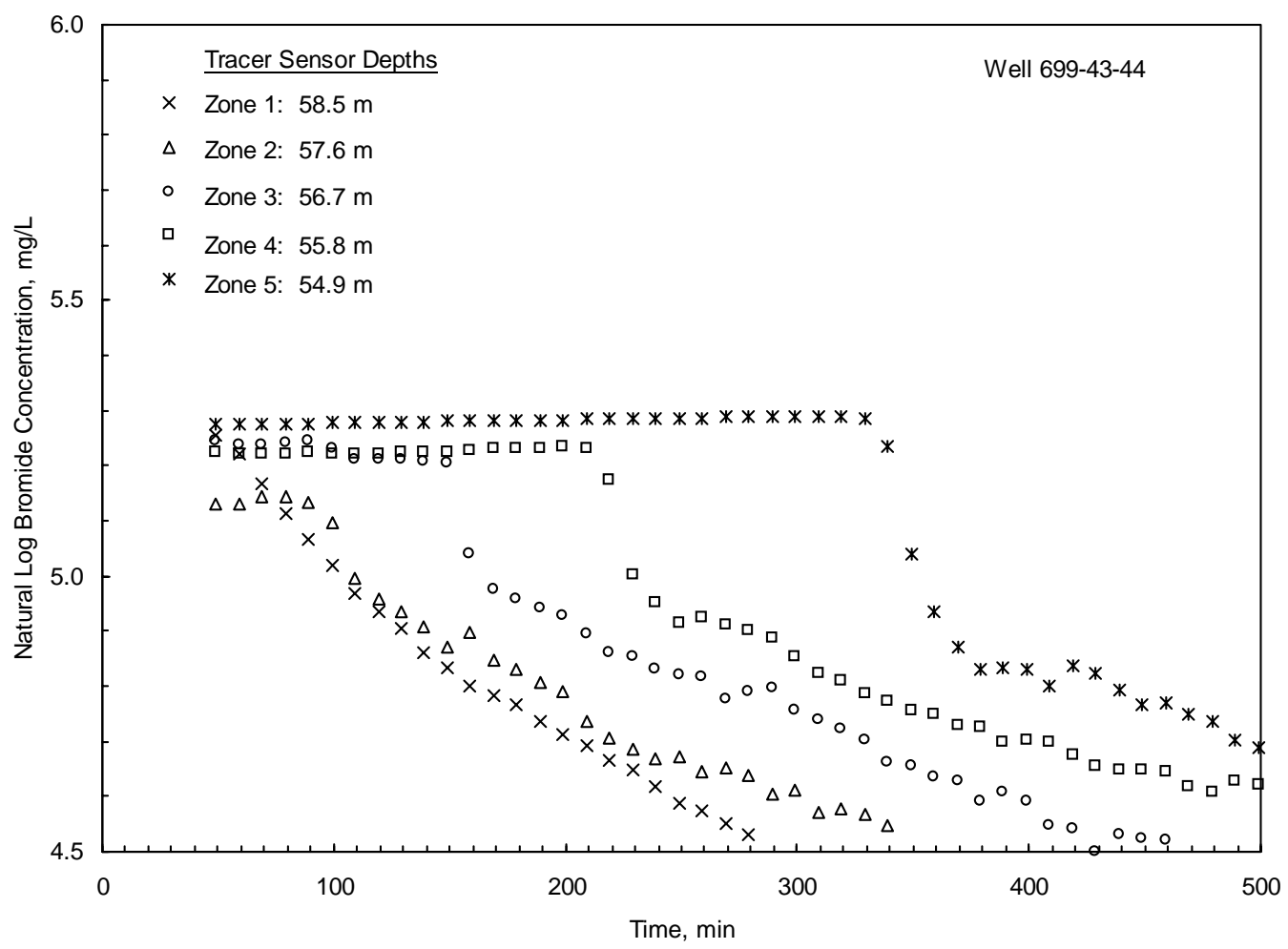

Figure 8.2. Tracer Concentration Versus Depth-Response Patterns Within Well 699-43-44 During Tracer-Dilution Testing 
dispense the tracer at the beginning of test. The tube was purged earlier with the tracer solution to remove air present within the delivery system. A custom-made flow diverter was attached at the tube bottom to promote areal placement of the tracer solution within the well-screen at the point of tracer introduction. Efforts were made to maintain the tracer solution at the expected fluid-column temperature of $\sim 17^{\circ} \mathrm{C}$ prior to its introduction.

Figure 8.3 shows the tracer versus time profiles for the various depth locations. Vertical flow velocities were calculated, based on the tracer peak arrival times between sensor-depth locations, divided by the distance spacing of $0.9 \mathrm{~m}$. To aid in the identification of the tracer peak arrival times, linearregression analysis of the tracer buildup and recovery limbs were employed for each sensor-depth location. The intersection of the buildup and recovery limb linear-regression lines provided the basis for the tracer peak arrival time determination. Linear-regression analysis was particularly useful for the top sensor-depth settings, where tracer profiles were broad and arrival peak discernment less visually obvious. Calculated flow velocities within well 699-43-44 were relatively uniform with depth within the well screen section and ranged between 0.006 and $0.008 \mathrm{~m} / \mathrm{min}$.

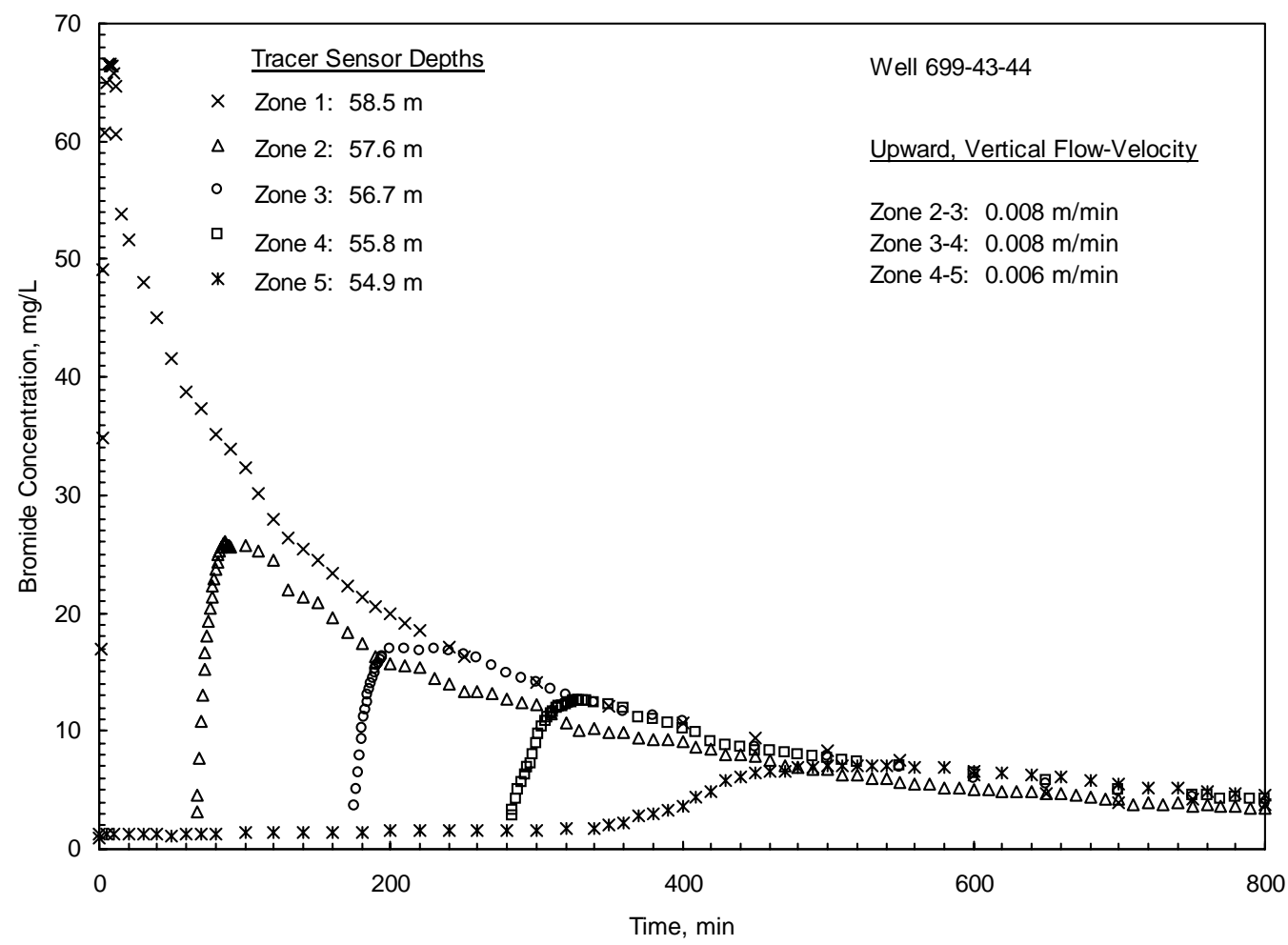

Figure 8.3. Tracer Concentration Versus Depth-Response Patterns Within Well 699-43-44 During In-Well, Vertical Flow Testing and Calculated, Upward, Vertical Flow Velocities 
The average vertical flow velocity was calculated by determining the depth to the center of the tracer mass within the well for selected test times. The slope of the linear regression of time versus the center of tracer mass provides the estimate of average, in-well, vertical flow. As shown in Figure 8.4 an average upward velocity of $0.006 \mathrm{~m} / \mathrm{min}$ was calculated for this test method. The average velocity is slightly less than the individual depth versus vertical flow velocity measurements, based on the tracer peak arrival method. Part of the slight differences calculated between methods may be attributed to the center-of-mass method assumption (i.e., that the tracer mass remains in the well during the period of analysis). Loss of tracer mass from the wellbore to the surrounding aquifer would cause in-well, vertical, flow velocities to be lower than actual.

Vertical flow measurements were obtained directly within well 699-43-44 on January 21, 2000 using an EM flow meter. Flow-meter results reported in Waldrop and Pearson (2000) over a $\sim 2$-m well-screen section (i.e., at 55.8 to $57.6 \mathrm{~m}$ below top of casing) provided velocity values between 0.001 and $0.014 \mathrm{~m} / \mathrm{min}$.

Table 8.1 summarizes the calculations determined within well 699-43-44. As indicated, comparable velocities and consistent indications of upward-flow conditions within the well-screen section were indicated by all three test methods. The fact that the flow-meter survey and tracer tests were conducted nearly 3 months apart, and still provided consistent results, suggests that the vertical flow condition is a persistent characteristic.

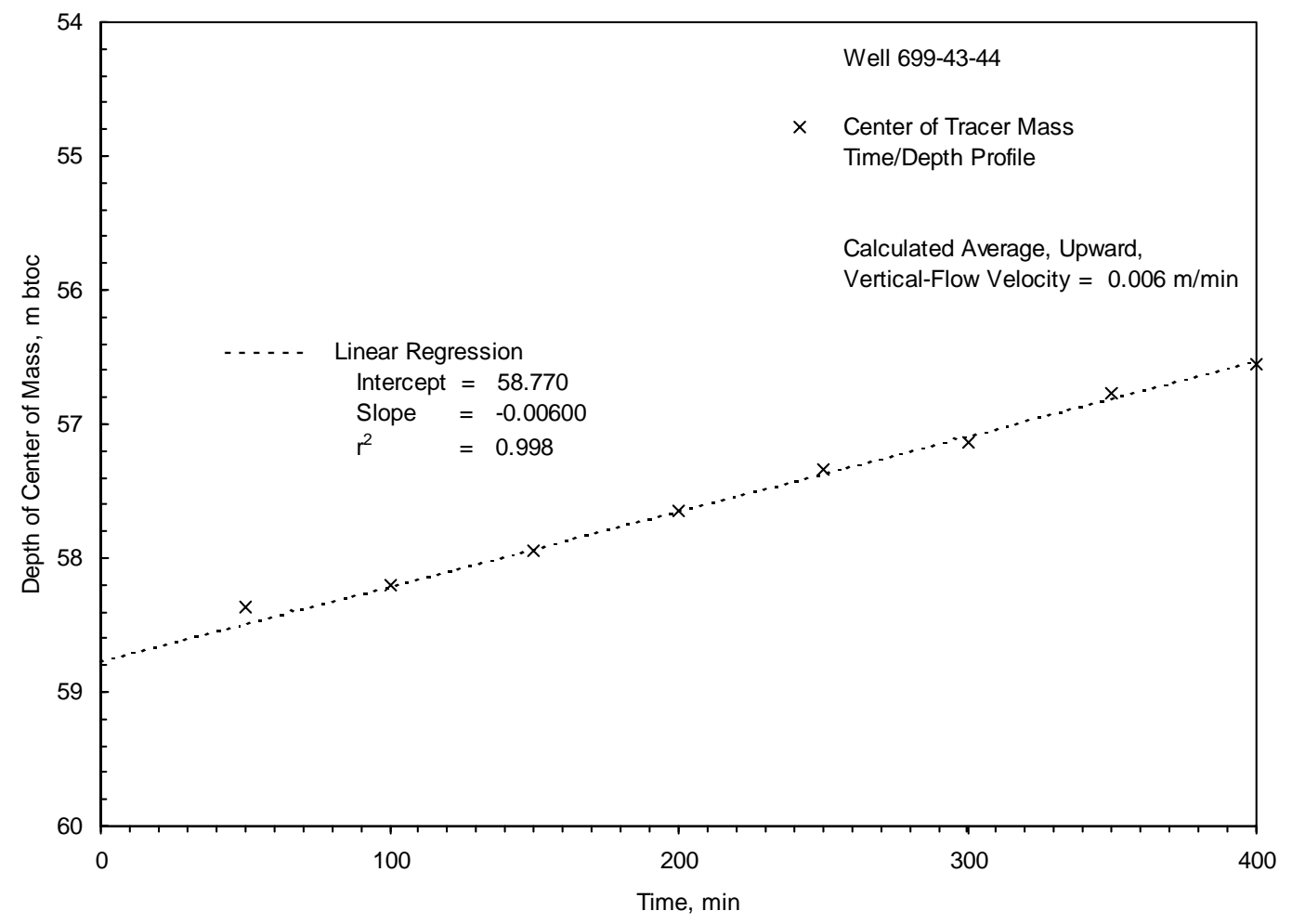

Figure 8.4. Calculated Average, In-Well, Upward, Vertical Flow Velocity Within Well 699-43-44, Using Center-of-Mass Method (btoc = below top of casing) 


\subsection{Conclusions}

The detailed hydrologic characterization of the Hanford Site's unconfined aquifer system conducted during FY 2000 included slug tests, single-well tracer tests (i.e., tracer-dilution; tracer-pumpback; and in-well, vertical flow-tracer tests), and constant-rate pumping tests. Hydraulic property estimates obtained from the detailed tests include hydraulic conductivity; transmissivity; specific yield; effective porosity; in-well, lateral, groundwater-flow velocity; aquifer groundwater-flow velocity; vertical distribution of hydraulic conductivity; and in-well, vertical flow velocity. In addition, the characteristics of local groundwater flow (i.e., hydraulic gradient, flow direction) were determined for five sites where detailed well testing was performed.

\subsection{Slug-Test and Constant-Rate Pumping Test Results}

Slug-test results provided hydraulic conductivity estimates that ranged between 1.4 and $19.9 \mathrm{~m} / \mathrm{d}$ for the eight 200-West Area wells, 41.8 and $52.1 \mathrm{~m} / \mathrm{d}$ for the two 200-East Area wells, and 1.7 to $2.0 \mathrm{~m} / \mathrm{d}$ for the one 600-Area well tested. Estimated values obtained using the Bouwer and Rice analytical method were generally lower and within $35 \%$ of the corresponding estimates obtained using the type-curve method. This is similar to findings of previous studies (e.g., Hyder and Butler 1995; Butler 1998) that evaluated the analytical performance of the Bouwer and Rice method. These findings are also consistent with results reported for Hanford Site tests conducted during FY 1999 (Spane et al., 2001). It should be noted that a wide range in hydraulic conductivity values is listed for the 200-West and 200-East Areas in several earlier reports (e.g., DOE/RL 1993; 200-West Area, 0.02 to $61 \mathrm{~m} / \mathrm{d}$ ). These results, however, were generally based on slug tests or single-well pumping tests that did not rely on the more exacting analytical methods utilized in this report.

A comparison of the slug test-derived hydraulic conductivity estimates with values obtained from constant-rate pumping tests is shown in Table 9.1. As indicated, a close correspondence is evident between the two test methods. For the comparisons, slug-test estimates calculated using the type-curve method were either equivalent to or up to $\sim 15 \%$ greater than pumping test-derived values. Slug-test estimates obtained using the Bouwer and Rice method ranged from either equivalent to $\sim 30 \%$ lower in comparison to their pumping test-derived counterparts. The estimate comparison exhibited falls within the error range commonly reported for slug tests in aquifer characterization studies (i.e., within a factor of $\sim 2$ or less [e.g., Butler 1996]). As noted in Butler (1998), the close correspondence between slug test and pumping test hydraulic conductivity estimates indicates that the formation tested can be represented as a homogeneous unit at the slug test or larger scale.

Analysis of the constant-rate pumping test results listed in Table 9.1 indicates that hydraulic property estimates for transmissivity ranged between 125 and $1130 \mathrm{~m}^{2} / \mathrm{d}$ (average $550 \mathrm{~m}^{2} / \mathrm{d}$ ). These values fall within to slightly above values recently calculated by Spane and Thorne (2000) for the central 200-West Area and reported by Spane et al. (2001) for constant-rate pumping tests conducted during FY 1999. As an additional source of comparison, large-scale transmissivity values of 300 and $327 \mathrm{~m}^{2} / \mathrm{d}$ were reported in Newcomb and Strand (1953) and Wurstner et al. (1995), respectively, for the unconfined aquifer within 
Table 9.1. Hydraulic Property Summary for Slug- and Constant-Rate Pumping Tests

\begin{tabular}{|c|c|c|c|c|c|}
\hline \multirow[b]{2}{*}{$\begin{array}{c}\text { Waste } \\
\text { Management } \\
\text { Area }\end{array}$} & \multirow[b]{2}{*}{ Well } & \multirow{2}{*}{$\begin{array}{c}\text { Slug Test }^{(\mathrm{a})} \\
\text { Hydraulic } \\
\text { Conductivity, } \\
\mathrm{K}_{\mathrm{h}}, \mathrm{m} / \mathrm{d}\end{array}$} & \multicolumn{3}{|c|}{ Constant-Rate Pumping Test } \\
\hline & & & $\begin{array}{c}\text { Hydraulic } \\
\text { Conductivity, } \\
\mathrm{K}_{\mathrm{h}}, \mathrm{m} / \mathrm{d}\end{array}$ & $\begin{array}{c}\text { Transmissivity, } \\
\mathrm{T}, \mathrm{m}^{2} / \mathrm{d}\end{array}$ & $\begin{array}{l}\text { Specific } \\
\text { Yield, } \\
\mathrm{S}_{\mathrm{y}}\end{array}$ \\
\hline \multirow[t]{6}{*}{ S-SX } & 299-W22-45 & $2.14-2.38$ & - (b) & 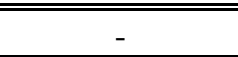 & 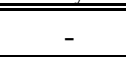 \\
\hline & 299-W22-46 & $2.43-3.37$ & - & - & - \\
\hline & 299-W22-48 & $1.42-1.86$ & 1.78 & 125 & 0.09 \\
\hline & 299-W22-49 & $6.04-7.97$ & 7.59 & 550 & 0.09 \\
\hline & 299-W22-50 & $4.24-5.70$ & 5.24 & 385 & 0.11 \\
\hline & 299-W23-15 & $1.55-1.58$ & - & - & - \\
\hline TX-TY & 299-W15-41 & $14.2-19.9$ & 19.6 & 1130 & 0.12 \\
\hline \multirow[t]{2}{*}{ B-BX-BY } & 299-E33-334 & $41.8-44.5$ & - & - & - \\
\hline & 299-E33-335 & $49.3-52.1$ & - & - & - \\
\hline $216-S-10$ & 299-W26-13 & $2.80-2.76$ & - & - & - \\
\hline B-Pond & $699-43-44$ & $1.74-1.95$ & 1.70 & 8.85 & 0.16 \\
\hline \multicolumn{6}{|c|}{$\begin{array}{l}\text { Note: Unless otherwise indicated, slug-test range represents the average analysis value for the Bouwer and Rice } \\
\text { and type-curve methods. } K_{h}=\text { Assumes aquifer with uniform hydraulic conductivity value. } \\
\text { (a) Listed range represents the average } K_{h} \text { value obtained from the Bouwer and Rice and type-curve analysis } \\
\text { methods. } \\
\text { (b) Constant-rate pumping test not conducted at the well site. }\end{array}$} \\
\hline
\end{tabular}

the 200-West Area. These previously reported values were based on analyzing the areal growth and decline of the groundwater mound that developed in this area as a result of wastewater disposal.

Comparison of the pumping test results in Table 9.1 also indicates a fairly close correspondence for specific yield, ranging between 0.09 and 0.16 . These results are comparable with the estimated values reported in Newcomb and Strand (1953) and Wurstner et al. (1995) of 0.11 and 0.17, respectively, for the 200-West Area. These earlier studies were based on analyzing the growth and decline of the groundwater mound beneath the 200-West Area that was associated with wastewater disposal in the area.

\subsection{Tracer-Dilution Test Results}

Table 9.2 lists the tracer-dilution results for the five wells tested. As discussed in Section 5.0, two of the five sites exhibited in-well, vertical flow conditions that compromise the results of this characterization test. Average, in-well, flow velocities for the three sites not exhibiting in-well vertical flow (i.e., wells 299-W15-41, 299-W22-48, and 299-W22-50) ranged between 0.007 to $0.311 \mathrm{~m} / \mathrm{d}$. (Note: As shown in Equation [3.5] and discussed in Section 3.2.1, in-well flow velocity is related, but not equivalent, to actual groundwater-flow velocity within the aquifer.) The highest value of $0.311 \mathrm{~m} / \mathrm{d}$ was calculated for well 299-W15-41, which is located in proximity (to the northeast) of the 200-ZP-1 pumpand-treat facilities. This well location is within the potential radius of influence distances reported in Spane and Thorne (2000) and, therefore, may be responsible for the elevated in-well flow velocities observed for this site. 
Table 9.2. Tracer-Dilution Test Summary

\begin{tabular}{|c|c|c|c|c|c|c|c|}
\hline Well & $\begin{array}{c}\text { Test } \\
\text { Interval, m, } \\
\text { btoc(a) }\end{array}$ & $\begin{array}{l}\text { Date Test } \\
\text { Initiated }\end{array}$ & $\begin{array}{l}\text { Total Dilution } \\
\text { Time, } t_{d}, \text { min }\end{array}$ & $\begin{array}{c}\text { Average Initial } \\
\text { Tracer } \\
\text { Concentration, } \\
\mathrm{C}_{0}{ }^{(b)} \mathrm{mg} / \mathrm{L}\end{array}$ & $\begin{array}{c}\text { Average Final } \\
\text { Tracer } \\
\text { Concentration, } \\
\mathrm{C}_{\mathrm{t}}{ }^{(\mathrm{c})} \mathrm{mg} / \mathrm{L}\end{array}$ & $\begin{array}{l}\text { Average } \\
\text { Flow } \\
\text { Velocity, } \\
\mathrm{v}_{\mathrm{w}}, \mathrm{m} / \mathrm{d}\end{array}$ & $\begin{array}{l}\text { Range Flow } \\
\text { Velocity, } \\
\mathrm{v}_{\mathrm{wz}}{ }^{(\mathrm{d})} \mathrm{m} / \mathrm{d}\end{array}$ \\
\hline 299-W15-41 & $66.0-71.1$ & $5 / 08 / 00$ & 2,714 & 152 & 1.3 & 0.311 & $0.232-0.401^{(\mathrm{e})}$ \\
\hline 299-W22-48 & $70.6-74.3$ & $5 / 11 / 00$ & 15,730 & 131 & 39.5 & 0.007 & $0.002-0.023^{(\mathrm{f})}$ \\
\hline 299-W22-49 & $67.3-71.8$ & $4 / 17 / 00$ & 4,175 & 145 & 4.0 & $\begin{array}{c}\mathrm{VF}^{(\mathrm{g})} \\
(0.086)\end{array}$ & $\begin{array}{c}\mathrm{VF}^{(\mathrm{g})} \\
\text { (upward) }\end{array}$ \\
\hline \multirow[t]{2}{*}{ 299-W22-50 } & \multirow[t]{2}{*}{$67.6-71.9$} & $5 / 01 / 00$ & 5,765 & 190 & 5.2 & 0.066 & uniform \\
\hline & & $5 / 26 / 00$ & 7,240 & 148 & 6.5 & 0.046 & uniform \\
\hline 699-43-44 & $54.1-59.0$ & $4 / 4 / 00$ & 4,045 & 204 & 0.8 & $\begin{array}{c}\mathrm{vf}^{(\mathrm{h})} \\
(0.180)\end{array}$ & $\begin{array}{c}\mathrm{vf}^{(\mathrm{h})} \\
\text { (upward) }\end{array}$ \\
\hline \multicolumn{8}{|c|}{$\begin{array}{l}\text { (a) Below top of casing. } \\
\text { (b) Estimated initial tracer concentration based on linear back-projection of average well-screen conditions. } \\
\text { (c) Average observed well-screen tracer concentration at termination of test. } \\
\text { (d) Groundwater flow-velocity range within well determined from individual sensor-depth settings. } \\
\text { (e) Permeability profile indicates highest permeability (highest flow velocity) near middle and lower section of well screen. } \\
\text { Permeability profile indicates highest permeability (highest flow velocity) occurs at top, becoming progressively lower with } \\
\text { depth within well-screen section. Significant vertical flow conditions that invalidate tracer-dilution test; vertical flow } \\
\text { direction indicated in parentheses. } \\
\text { (h) Slight vertical flow conditions detected adversely affect tracer-test results; vertical flow direction indicated in parentheses. }\end{array}$} \\
\hline
\end{tabular}

A comparison of the observed depth versus velocity profiles provided information about permeability distribution within the well-screen sections at the three well sites. At well 299-W15-41, the highest flow velocities (and inferred permeabilities) were exhibited near the middle and lower section of the well screen, while at well 299-W22-48 the highest flow velocities were indicated near the top. In contrast, for well 299-W22-50, relatively uniform depth versus velocity profiles were exhibited, indicating homogeneous permeability conditions throughout the well-screen section.

Two tracer-dilution tests were conducted at the well 299-W22-50 to assess the reproducibility of tracer test results. The calculated average $\mathrm{v}_{\mathrm{w}}$ differed by $\sim 30 \%$ for the two tests (i.e., $0.066 \mathrm{~m} / \mathrm{d}$ vs. $0.046 \mathrm{~m} / \mathrm{d}$ ). It is not known whether the difference in the calculated $\mathrm{v}_{\mathrm{w}}$ can be ascribed to changes in actual test site conditions (e.g., hydraulic gradient during the two tests) or due to insensitivities of the test.

\subsection{Tracer-Pumpback Test Results}

Table 6.1 lists information pertaining to the tracer-pumpback tests performed. As noted previously, two wells exhibited vertical-flow conditions during the tracer-dilution tests. The fact that the tracer entered the aquifer within a small portion of the well screen seriously impacts the assumptions of the test. The tracer-pumpback results for those wells affected by vertical flow conditions are highly questionable and, therefore, should not be used for quantitative assessment. The estimates calculated from the tests, however, are provided in the table for comparison/informational purposes only. 
Estimates for effective porosity ranged between 0.068 and 0.354 . This range falls within, to slightly above, the range commonly reported for semiconsolidated to unconsolidated alluvial aquifers $(0.05$ to $0.30)$ and encompass the large-scale values for specific yield, $S_{y}\left(S_{y} \approx n_{e}\right)$ of 0.11 and 0.17 , derived from the constant-rate pumping tests. The highest value for effective porosity was determined for the first of two tracer tests conducted at well 299-W22-50. The effective porosity value of 0.272 calculated for the second tracer test, however, is considered to be more representative of actual aquifer conditions. This is attributed to the longer tracer residence time during the second test ( $\mathrm{t}_{\mathrm{d}}=7,240 \mathrm{vs}$. 5,765 minutes), and the fact that the hydraulic gradient, I, used in Equation (3.8) is based on well water-level measurements taken during the test period.

Estimates for groundwater-flow velocity within the aquifer ranged between 0.013 and $0.374 \mathrm{~m} / \mathrm{d}$ and generally fall within a factor of 2.5 of the calculated, in-well, flow velocities. A similar relationship between groundwater-flow velocity estimates and calculated in-well flow velocities was reported in Spane et al. (2001) for tracer tests conducted during FY 1999. As noted at well 299-W15-41, the observed estimate of $0.374 \mathrm{~m} / \mathrm{d}$ at this well site may be elevated as a result of the effects imposed by operation of the adjacent 200-ZP-1 pump-and-treat system.

\subsection{In-Well, Vertical Flow-Test Results}

The tracer concentration versus depth-response patterns exhibited during the tracer-dilution tests conducted in wells 299-W22-49 and 699-43-44 exhibited evidence of vertical flow conditions within the well-screen section. The cause of the induced flow conditions is not known but may be the result of either 1) proximity to local recharge areas, 2) heterogeneous formation conditions along the well screen, or 3 ) temporal effects from neighboring well-pumping/-sampling activities. To corroborate the upward vertical flow conditions calculated during the tracer-dilution tests, a follow-up, in-well, vertical, flow-tracer test and/or a direct, vertical, flow survey (Waldrop and Pearson 2000) were conducted at both well sites. The results of the calculations determined from the three methods are summarized in Table 8.1. As indicated in Table 8.1, consistent and comparable estimates were obtained using three methods, with well 299-W22-49 exhibiting slightly higher average vertical velocities $(0.010$ to $0.012 \mathrm{~m} / \mathrm{min})$ than determined at well 699-43-44 (0.006 to $0.011 \mathrm{~m} / \mathrm{min})$. Similar consistency between methods was described in Spane et al. (2001) for two wells characterized in FY 1999, where downward, in-well vertical flow conditions were detected.

The existence of in-well vertical flow is not necessarily reflective of actual groundwater-flow conditions within the surrounding aquifer, but its presence has implications pertaining to the representativeness of groundwater samples collected from such monitor well facilities (i.e., water samples collected from the well may not be reflective of aquifer materials within the entire well-screen section). The fact that the flow-meter survey and flow-tracer tests were conducted nearly 3 months apart, and still provided consistent results, suggests that the vertical flow condition is a persistent characteristic at these well sites. 
Table 9.3. Groundwater-Flow Characterization Results Based on Trend-Surface Analysis

\begin{tabular}{|c|c|c|c|c|}
\hline Well & $\begin{array}{c}\text { Measurement } \\
\text { Date }\end{array}$ & $\begin{array}{l}\text { Groundwater-Flow } \\
\text { Direction }^{(a)}\end{array}$ & $\begin{array}{c}\text { Hydraulic Gradient, } \\
\mathrm{m} / \mathrm{m}\end{array}$ & $\begin{array}{l}\text { Wells Used } \\
\text { in Analysis }\end{array}$ \\
\hline 299-W15-41 & $5 / 8 / 00$ & $286^{\circ}$ & 0.00129 & $\begin{array}{c}299-W 14-5 \\
299-W 14-6 \\
299-W 14-14 \\
299-W 15-40 \\
299-W 15-41\end{array}$ \\
\hline 299-W22-48 & $5 / 17 / 00$ & $2^{\circ}$ & 0.0018 & $\begin{array}{l}299-W 22-45 \\
299-W 22-48 \\
299-W 23-13\end{array}$ \\
\hline 299-W22-49 & $5 / 31 / 00$ & $1^{\circ}$ & 0.00206 & $\begin{array}{l}299-W 22-49 \\
299-W 22-50 \\
299-W 23-14 \\
299-W 23-15\end{array}$ \\
\hline \multirow{2}{*}{$299-W 22-50$} & $5 / 17 / 00$ & $359^{\circ}$ & 0.00204 & $\begin{array}{l}299-W 22-49 \\
299-W 22-50 \\
299-W 23-14 \\
299-W 23-15\end{array}$ \\
\hline & $5 / 31 / 00$ & $1^{\circ}$ & 0.00206 & $\begin{array}{l}299-W 22-49 \\
299-W 22-50 \\
299-W 23-14 \\
299-W 23-15\end{array}$ \\
\hline
\end{tabular}

\subsection{Groundwater-Flow Characterization Results}

Table 9.3 lists results pertaining to the determination of groundwater-flow direction and hydraulic gradient conditions at the various sites during the period of tracer testing. Groundwater-flow direction and hydraulic gradient were calculated using the commercially available WATER-VEL (In-Situ, Inc. 1991) software program. Water-level elevations from neighboring, representative wells were used as input to the WATER-VEL program to calculate groundwater-flow direction and hydraulic gradient conditions during the detailed characterization period. The program uses a linear, two-dimensional trend surface (least squares) to randomly located hydrologic head or water-level elevation input data. This method is similar also to the linear approximation technique described by Abriola and Pinder (1982) and Kelly and Bogardi (1989). Reports that demonstrate the use of the WATER-VEL program for calculation of groundwater-flow velocity and direction on the Hanford Site include Gilmore et al. (1992), Spane (1999), and Spane et al. (2001).

The hydraulic gradient calculations listed in Table 9.3 were used in calculating the estimates of effective porosity and groundwater-flow velocity shown in Table 6.1. The indicated easterly and southeasterly groundwater-flow directions are consistent with generalizations presented in Hartman et al. (2000) for these wells. 


\subsection{References}

Abriola LM, and GF Pinder. 1982. "Calculation of velocity in three space dimensions from hydraulic head measurements." Ground Water 20(2):205-213.

Agarwal RG. 1980. "A new method to account for producing time effects when drawdown type curves are used to analyze pressure buildup and other test data." SPE Paper 9289, Society of Petroleum Engineers, Dallas Texas.

Bourdet DJ, A Ayoub, and YM Pirard. 1989. "Use of pressure derivative in well-test interpretation." SPE Formation Evaluation June 1989:293-302.

Bouwer H. 1989. “The Bouwer and Rice slug test - an update.” Ground Water 27(3):304-309.

Bouwer H. 1996. "Discussion of Bouwer and Rice slug test review articles." Ground Water, 34(1):171.

Bouwer H, and RC Rice. 1976. “A slug test for determining hydraulic conductivity of unconfined aquifers with completely or partially penetrating wells." Water Resources Research 12(3):423-428.

Brown DL, TN Narasimhan, and Z Demir. 1995. "An evaluation of the Bouwer and Rice method of slug test analysis." Water Resources Research 31(5):1239-1246.

Butler JJ, Jr. 1990. "The role of pumping tests in site characterization: some theoretical considerations." Ground Water 28(3):394-402

Butler JJ, Jr. 1996. "Slug tests in site characterization: some practical considerations." Environmental Geosciences 3(3):154-163

Butler JJ, Jr. 1998. The design, performance, and analysis of slug tests. Lewis Publishers, CRC Press, Boca Raton, Florida.

Butler, JJ, Jr., GC Bohling, ZH Hyder, and CD McElwee. 1994. "The use of slug tests to describe vertical variations in hydraulic conductivity." Journal of Hydrology 156:137-162.

Butler JJ, CD McElwee, and W Liu. 1996. "Improving the quality of parameter estimates obtained from slug tests." Ground Water 34(3):480-490.

Connelly MP, JV Borghese, CD Delaney, BH Ford, JW Lindberg, and SJ Trent. 1992a. Hydrogeologic model for the 200-East groundwater aggregate area. WHC-SD-EN-TI-019, Rev. 0, Westinghouse Hanford Company, Richland, Washington.

Connelly MP, BH Ford, and JV Borghese. 1992b. Hydrogeologic model for the 200-West groundwater aggregate area. WHC-SD-EN-TI-014, Rev. 0, Westinghouse Hanford Company, Richland, Washington. 
Cooper HH, Jr., and CE Jacob. 1946. “A generalized graphical method for evaluating formation constants and summarizing well-field history." American Geophysical Union, Transactions 27(4):526-534.

DOE/RL. 1993. 200 West groundwater aggregate area management study report. DOE/RL-92-16, Rev. 0, U.S. Department of Energy, Richland Operations Office, Richland, Washington.

Drost W, D Klotz, A Koch, H Moser, F Neumaier, and W Rauert. 1968. "Point dilution methods of investigating groundwater flow by means of radioisotopes." Water Resources Research 4(1):125-146.

Freeze RA, and JA Cherry. 1979. Groundwater. Prentice-Hall, Englewood Cliffs, New Jersey.

Gephart RE, FA Spane, LS Leonhart, DA Palombo, and SR Strait. 1979. "Pasco Basin hydrology." In Hydrologic studies within the Columbia plateau, Washington: An integration of current knowledge, pp. III-1 to III-236. RHO-BWI-ST-5, Rockwell Hanford Operations, Richland, Washington.

Gilmore TJ, DR Newcomer, SK Wurstner, and FA Spane, Jr. 1992. Calculation of groundwater discharge to the Columbia River in the 100-N area. PNL-8057, Pacific Northwest Laboratory, Richland, Washington.

Graham MJ, GV Last, and KR Fecht. 1984. An assessment of aquifer intercommunication in the B-Pond-Gable Mountain Pond area of the Hanford site. RHO-RE-ST-12P, Rockwell Hanford Operations, Richland, Washington.

Güven O, RW Falta, FJ Molz, and JG Melville. 1985. "Analysis interpretation of single-well tracer tests in stratified aquifers." Water Resources Research 21(5):676-684.

Guyonnet D, S Mishra, J McCord. 1993. "Evaluating the volume of porous medium investigated during slug tests." Ground Water 31(4):627-633.

Halevy E, H Moser, O Zellhofer, and A Zuber. 1966. "Borehole dilution techniques - a critical review." In Isotopes in Hydrology, International Atomic Energy Agency, Vienna, Austria.

Hall SH. 1993. "Single well tracer tests in aquifer characterization." Ground Water Monitoring \& Remediation 13(2):118-124.

Hall SH, SP Luttrell, and WE Cronin. 1991. "A method for estimating effective porosity and groundwater velocity." Ground Water 29(2):171-174.

Hantush, MS. 1964. "Hydraulics of wells." Advances in Hydroscience (VT Chow, ed) 1:282-433, Academic Press, New York.

Hartman MJ, LF Morasch, and WD Webber, (eds). 2000. Hanford Site groundwater monitoring for fiscal year 1999. PNNL-13116, Pacific Northwest National Laboratory, Richland, Washington. 
Hyder Z, and JJ. Butler, Jr. 1995. "Slug tests in unconfined formations: An assessment of the Bouwer and Rice technique." Ground Water 33(1):16-22.

In-Situ Inc. 1991. WATER-VEL ${ }^{T M}$ groundwater velocity. ISI-GWV-2.21-1, Laramie, Wyoming.

Karasaki K, JCS Long, and PA Witherspoon. 1988. "Analytical models of slug tests.” Water Resources Research 24(1):115-126.

Kearl PM, JJ Dexter, and JE Price. 1988. Procedures, analysis, and comparison of groundwater velocity measurement methods for unconfined aquifers. UNC/GJ-TMC-3, UNC Geotech, Grand Junction, Colorado.

Kelly WE, and I Bogardi. 1989. "Flow directions with a spreadsheet." Ground Water-Computer Notes 27(2):245-247.

Leap DI, and PG Kaplan 1988. "A single-well tracing method for estimating regional advective velocity in a confined aquifer: Theory and preliminary laboratory verification." Water Resources Research 24(7):993-998.

Lindsey KA. 1995. Miocene- to Pliocene-aged suprabasalt sediments of the Hanford Site, south-central Washington. BHI-00184, Bechtel Hanford Inc., Richland, Washington.

Lindsey KA, BN Bjornstad, JW Lindberg, and KM Hoffman. 1992. Geologic setting of the 200-East area: An update. WHC-SD-EN-TI-012, Rev. 0, Westinghouse Hanford Company, Richland, Washington.

Liu WZ, and JJ Butler, Jr. 1995. The KGS model for slug tests in partially penetrating wells (Version 3.0). Kansas Geological Survey Computer Series Report 95-1, Lawrence, Kansas.

Michalski A. 1989. "Conductive slug tracing as a single-well test technique for heterogeneous and fractured formations." In Proceedings of the Conference on New Field Techniques for Quantifying the Physical and Chemical Properties of Heterogeneous Aquifers, March 20-23, 1989, Dallas, Texas; pp 247-263. National Water Well Association, Dublin, Ohio.

Michalski A, and GM Klepp. 1990. "Characterization of transmissive fractures by simple tracing of in-well flow." Ground Water 28(2):191-198.

Moench AF. 1997. "Flow to a well of finite diameter in a homogeneous, anisotropic water-table aquifer." Water Resources Research 33(6):1397-1407.

Moench AF, and PA Hsieh. 1985. "Analysis of slug test data in a well with finite-thickness skin." In Memoirs Hydrogeology of Rocks of Low Permeability, January 7-12, 1985, Tucson, Arizona; International Association of Hydrogeologists 17(1):17-29. 
Molz FJ, JG Melville, O Güven, RD Crocker, and KT Matteson. 1985. "Design and performance of single-well tracer tests at the Mobile site." Water Resources Research 21(10):1497-1502.

Neuman SP. 1972. "Theory of flow in unconfined aquifers considering delayed response of the water table." Water Resources Research 8(4):1031-1045.

Neuman SP. 1974. "Effect of partial penetration of flow in unconfined aquifer considering delayed gravity response." Water Resources Research 10(2):303-312.

Neuman SP. 1975. "Analysis of pumping test data from anisotropic unconfined aquifers considering delayed gravity response." Water Resources Research 11(2):329-342.

Newcomb RC, and JR Strand. 1953. Geology and ground-water characteristics of the Hanford Reservation of the U.S. Atomic Energy Commission, Washington. Administrative Report WP-8, U.S. Geological Survey, Washington, D.C.

Novakowski KS. 1989. “Analysis of pulse interference tests.” Water Resources Research 25(11):2377-2387.

Pickens JF, and GE Grisak. 1981. "Scale-dependent dispersion in a stratified granular aquifer." Water Resources Research 17(4):1191-1211.

Rasmussen TC, and LA Crawford. 1997. "Identifying and removing barometric pressure effects in confined and unconfined aquifers." Ground Water 35(3):502-511.

Reilly TE, OL Franke, and GD Bennett. 1989. "Bias in groundwater samples caused by wellbore flow." Journal of Hydraulic Engineering 115(2):270-276.

Resource Conservation and Recovery Act of 1976, as amended, Public Law 94-580, 90 Stat. 2795, 42 USC 6901 et seq.

Spane FA, Jr. 1993. Selected hydraulic test analysis techniques for constant-rate discharge tests. PNL-8539, Pacific Northwest Laboratory, Richland, Washington.

Spane FA, Jr. 1996. "Applicability of slug interference tests for hydraulic characterization of unconfined aquifer: (1) Analytical assessment." Ground Water 34(1):66-74.

Spane FA, Jr. 1999. Effects of barometric fluctuations on well water-level measurements and aquifer test data. PNNL-13078, Pacific Northwest National Laboratory, Richland, Washington.

Spane FA, Jr., and PD Thorne. 2000. Analysis of the hydrologic response associated with shutdown and restart of the 200-ZP-1 pump-and-treat system. PNNL-13342, Pacific Northwest National Laboratory, Richland, Washington. 
Spane FA, Jr., and WD Webber. 1995. Hydrochemistry and hydrogeologic conditions within the Hanford Site upper basalt confined aquifer system. PNL-10817, Pacific Northwest Laboratory, Richland, Washington.

Spane FA, Jr., and SK Wurstner. 1993. "DERIV: A program for calculating pressure derivatives for use in hydraulic test analysis." Ground Water 31(5):814-822.

Spane FA, Jr., PD Thorne, and LC Swanson. 1996. "Applicability of slug interference tests for hydraulic characterization of unconfined aquifer: (2) Field test examples." Ground Water 34(5):925-933.

Spane FA, Jr., PD Thorne, and DR Newcomer. 2001. Results of detailed hydrologic characterization tests - fiscal year 1999. PNNL-13378, Pacific Northwest National Laboratory, Richland, Washington.

Theis CV. 1935. "The relationship between the lowering of the piezometric surface and the rate and duration of discharge of a well using ground-water storage." American Geophysical Union, Transactions, 2:519-524; reprinted in Society of Petroleum Engineers, "Pressure Transient Testing Methods," SPE Reprint Series (14):27-32, Dallas, Texas.

Thorne PD, MA Chamness, FA Spane, Jr., VR Vermeul, and WD Webber. 1993. Three-dimensional conceptual model for the Hanford Site unconfined aquifer system, FY 93 status report. PNL-8971, Pacific Northwest Laboratory, Richland, Washington.

Waldrop WR, and HS Pearson. 2000. Results of field tests with the electromagnetic borehole flowmeter at the Pacific Northwest National Laboratory, Richland, Washington. QEC-T-132, Quantum Engineering Corporation, Loudon, Tennessee.

Weeks EP. 1979. "Barometric fluctuations in wells tapping deep unconfined aquifers." Water Resources Research 15(5):1167-1176.

Williams BA, BN Bjornstad, R Schalla, and WD Webber. 2000. Revised hydrogeology for the suprabasalt aquifer system, 200-East area and vicinity, Hanford Site, Washington. PNNL-12261, Pacific Northwest National Laboratory, Richland, Washington.

Wurstner SK, PD Thorne, MA Chamness, MD Freshley, and MD Williams. 1995. Development of a three-dimensional ground-water model of the Hanford Site unconfined aquifer system: FY 1995 status report. PNL-10886, Pacific Northwest Laboratory, Richland, Washington. 


\section{Distribution}

No. of

Copies

\section{OFFSITE}

M. L. Blazek

State of Oregon Office of Energy

625 Marion Street N.E.

Salem, OR 97310

J. S. Bachmaier

U.S. Department of Energy

Forrestal Building, EH-412

1000 Independence Avenue, S.W.

Washington, D.C. 20585

2 Confederated Tribes of the Umatilla Indian Reservation

P.O. Box 638

Pendleton, OR 97801

ATTN: W. Burke

S. Harris

R. A. Danielson

State of Washington Department of Health 2 South $45^{\text {th }}$ Avenue

Yakima, WA 98908

B. W. Drost

Geological Survey

U.S. Department of the Interior

1201 Pacific Avenue, Suite 600

Tacoma, WA 98402

M. K. Harmon

U.S. Department of Energy

Cloverleaf Building, EM-44

19901 Germantown Road

Germantown, MD 20874-1290

W. N. Herkelrath

Geological Survey

U.S. Department of the Interior

345 Middlefield Road, MS 496

Menlo Park, CA 94025
No. of

Copies

2 Idaho National Engineering and Environmental Laboratory

Lockheed Martin Idaho Technology Co.

P.O. Box 1625

Idaho Falls, ID 83415-2107

ATTN: J. M. Hubbell

J. B. Sisson

Nez Perce Tribe

Environmental Restoration/Waste

Management

P.O. Box 365

Lapwai, ID 83540-0365

ATTN: P. Sobotta

2 Schlumberger HydroGeological

Technologies

6090 Greenwood Plaza Blvd.

Englewood, CO 80111

ATTN: R. Lewis

N. Clayton

2 State of Washington

Department of Health

Division of Radiation Protection

P.O. Box 47827

Olympia, WA 98504-7827

ATTN: D. McBaugh

G. Robertson

3 Wanapum People

Grant County P.U.D.

P.O. Box 878

Ephrata, WA 98823

ATTN: R. Buck

L. Seelatsee

R. Tomanawash

Distr.1 
No. of

Copies

2 Yakama Indian Nation

Environmental Restoration/Waste

Management Program

2802 Main Street

Union Gap, WA 98903

ATTN: R. Jim

W. Rigsby

Foreign

M. Hagood

Schlumberger

Parkstraat 83

2514 JG The Hague

The Netherlands

9 DOE Richland Operations Office

B. L. Foley

$\mathrm{H} 0-12$

M. J. Furman

$\mathrm{H} 0-12$

R. D. Hildebrand

$\mathrm{H} 0-12$

$\mathrm{H} 0-12$

$\mathrm{H} 0-12$

H0-12

H6-60

$\mathrm{H} 2-53$

4 Bechtel Hanford, Inc.
G. A. Day
B. H. Ford
R. L. Jackson
G. B. Mitchem

H0-19

H0-21

H0-19

H0-21

4 CH2M HILL Hanford, Inc.

J. V. Borghese

H0-21

W. J. McMahon

V. J. Rohay

L. C. Swanson

2 CH2M HILL Hanford Group

A. J. Knepp

D. J. Meyer

$\mathrm{H} 0-22$

S8-09
No. of

Copies

ONSITE

3 State of Washington Department of Ecology

J. Caggiano B5-18

D. Goswami B5-18

A. Huckaby B5-18

2 U.S. Environmental Protection Agency

D. A. Faulk B5-01

D. R. Sherwood B5-01

4 Duratek Federal Services, Inc.

D. R. Brewington H1-11

M. G. Gardner H1-11

D. E. Hollingsworth H1-11

S. H. Worley H1-11

4 Fluor Hanford, Inc.

R. D. Haggard G1-29

K. J. Lueck S6-72

P. M. Olson S6-72

R. W. Szelmeczka S6-72

42 Pacific Northwest National Laboratory

D. B. Barnett K6-81

M. P. Bergeron K9-36

M. A. Chamness K6-85

C. R. Cole K9-36

P. E. Dresel K6-96

M. J. Fayer K9-33

M. D. Freshley K9-36

J. S. Fruchter K6-96

T. J Gilmore K6-81

M. J. Hartman K6-96

F. N. Hodges K6-81

V. G. Johnson K6-96

C. T. Kincaid K9-33

G. V. Last K6-81

J. W. Lindberg K6-81 
No. of

Copies

S. P. Luttrell

J. P. McDonald

R. B. Mercer

S. M. Narbutovskih

D. R. Newcomer

R. E. Peterson

J. T. Rieger

R. Schalla

R. M. Smith
No. of

Copies

K6-96

K6-96

K6-96

K6-96

K6-96

K6-96

K6-96

K6-96

K6-96
F. A. Spane, Jr. (5)

D. L. Stewart

M. D. Sweeney

P. D. Thorne (5)

E. C. Thornton

W. D. Webber

B. A. Williams

S. K. Wurstner

Hanford Technical Library (2)
K6-96

K6-96

K6-81

K9-33

K6-96

K6-96

K6-81

K9-36

P8-55

Distr.3 